Arkivoc

Free to Authors and Readers
A Platinum Open Access Journal for Organic Chemistry
Review

DOAJ Seal

Arkivoc 2021, part i, 329-377

\title{
Aminouracil and aminothiouracil as versatile precursors for a variety of heterocyclic systems
}

\author{
Hadeer M. Diab, Mostafa E. Salem, Ismail A. Abdelhamid* and Ahmed H. M. Elwahy* \\ Chemistry Department, Faculty of Science, Cairo University, Giza, Egypt \\ E-mail: aelwahy@hotmail.com
}

Received 01-20-2021

Accepted 03-05-2021

Published on line 04-14-2021

\section{Abstract}

Heterocycles, particularly pyrimidine derivatives, which are present in many natural products and many interesting synthetic compounds, are the most diverse class of organic compounds and have significant chemical, biomedical and industrial applications. Uracil, a pyrimidine derivative, constitutes a promising structure in widespread natural products and many of its derivatives exhibited significant pharmacological properties. They have been widely used as starting materials for the synthesis of a huge number of biologically important nitrogen-containing heterocycles. This review casts light on various methods for the construction of different heterocyclic systems utilizing aminouracil and aminothiouracil as versatile precursors. The heterocyclic systems mentioned in this review are categorized according to the type of the heterocyclic systems.

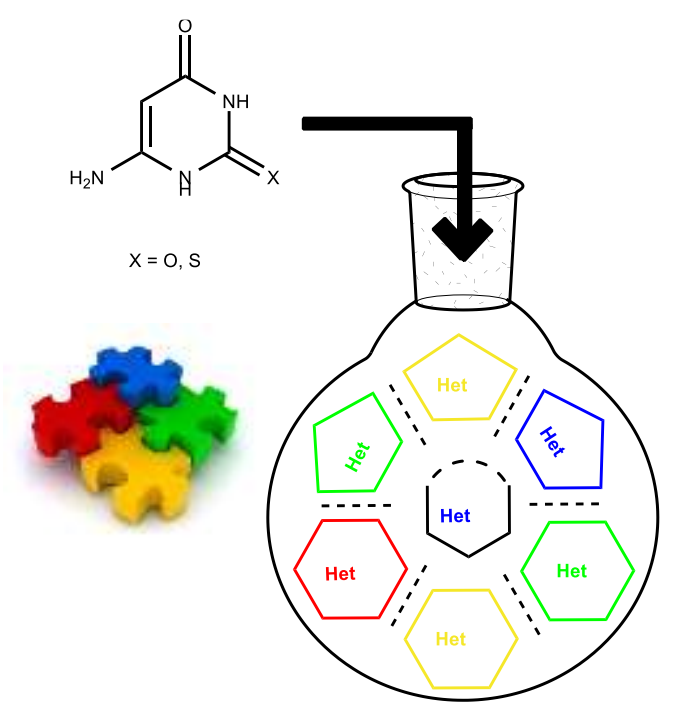

Keywords: Aminouracil, aminothiouracil, synthesis, heterocyclic systems 


\section{Table of Contents}

1. Introduction

2. Synthesis of Aminouracil and Aminothiouracil

3. Synthesis of Heterocyclic Compounds using Aminouracil and Aminothiouracil

3.1. Synthesis of substituted aminouracil (thiouracil) derivatives

3.1.1 N-Alkylation reaction

3.1.2 S-Alkylation reaction

3.1.3 C-Alkylation reaction

3.2. Synthesis of uracil-fused heterocycles

3.2.1 Synthesis of fused bicyclic systems

3.2.1.1 Fused [5-6]systems: Three heteroatoms

3.2.1.1.1 Synthesis of pyrrolo[2,3- $d$ ] pyrimidines

3.2.1.1.2 Synthesis of thiazolo[3,2-a]pyrimidine

3.2.1.2 Fused [5-6]systems: Four heteroatoms

3.2.1.2.1. Synthesis of thiazolo[4,5- $d$ ] pyrimidine

3.2.1.2.2 Synthesis of triazolo[4,3-a]pyrimidine

3.2.1.3. Fused [6-6]systems: Three heteroatoms

3.2.1.3.1. Synthesis of pyrido[2,3- $d$ ] pyrimidine

3.2.1.3.2 Synthesis of pyrimido[1,6-a]pyrimidine

3.2.1.4 Fused [6-6]systems: Four heteroatoms

3.2.1.4.1 Synthesis of pyrimido[4,5-d]pyrimidine

3.2.2 Synthesis of fused tricyclic systems

3.2.2.1 Fused [5-6-6]systems: Three heteroatoms

3.2.2.1.1 Synthesis of cyclopenta[5,6]pyrido[2,3- $d$ ]pyrimidine

3.2.2.2 Fused [5-6-6]systems: five heteroatoms

3.2.2.2.1 Synthesis of pyrazolo[ $\left.4^{\prime}, 3^{\prime}: 5,6\right]$ pyrido[2,3-d]pyrimidin-5-one

3.2.2.2.2 Synthesis of isoxazolo[ $\left.4^{\prime}, 5^{\prime}: 5,6\right]$ pyrido[2,3-d]pyrimidine

3.2.2.3 Fused [6-6-6]systems: three heteroatoms

3.2.2.3.1 Synthesis of pyrimido[4,5-b]quinolone

3.2.2.4 Fused [6-6-6]systems: Four heteroatoms

3.2.2.4.1 Synthesis of pyrimido[4,5- $h][1,6]$ naphthyridin-10(7H)-one

3.2.2.4.2 Synthesis of pyrimido[4,5- $b]-1,8$-naphthyridine

3.2.2.5 Fused [6-6-6]systems: Five heteroatoms

3.2.2.5.1 Synthesis of pyrimido[ $\left[5^{\prime}, 4^{\prime}: 5,6\right]$ pyrido[4,3-c]pyridazine

3.2.2.5.2 Synthesis of pyrido[2,3- $\left.d: 4,5-d^{\prime}\right]$ dipyrimidine

3.2.2.5.3 Synthesis of pyrido[2,3- $\left.d: 6,5 d^{\prime}\right]$ dipyrimidine

3.2.2.5.4 Synthesis of 2,5,7,9,11-pentaazaphenalenes

3.2.2.6 Fused [6-6-6]systems: (six heteroatoms)

3.2.2.6.1 Synthesis of pyrimido[4,5-g]pteridine

3.2.3 Synthesis of fused tetracyclic systems

3.2.3.1 Fused [6-5-6-6]systems: Three heteroatoms

3.2.3.1.1 Synthesis of indeno[ $\left.2^{`}, 1^{`}: 5,6\right]$ pyrido[2,3- $\left.d\right]$ pyrimidine

3.2.3.2 Fused [5-6-6-6]systems: Three heteroatoms 
3.2.3.2.1. Synthesis of furo[3,2-g]pyrimido[1,6-a]quinazolin-3-one

3.2.3.3. Fused [6-6-6-6]systems: Three heteroatoms

3.2.3.3.1. Synthesis of benzo[ $g]$ pyrimido[4,5- $b]$ quinolintrione

3.2.3.3.2. Synthesis of pyrido[3,2,1-ij]pyrimido[4,5-b]quinoline-7,5'-pyrrolo[2,3- $d$ ]pyrimidine

3.2.3.4. Fused [6-6-6-6]systems: Four heteroatoms

3.2.3.4. Synthesis of chromeno[ $\left[4^{\prime}, 3^{\prime}: 4,5\right]$ pyrido[2,3- $\left.d\right]$ pyrimidine

4. Conclusions

References

\section{Introduction}

Heterocyclic compounds are being used in several areas, including agrochemistry, medicine, polymer science, and various industries. They have gained significant interest in the design of biologically active molecules and are of great importance for the chemistry of life since their structural subunits occur in many natural products such as vitamins, hormones, and antibiotics. They play an active role in numerous medical applications as antiviral, anti-bacterial, anti-inflammatory, anti-fungal, and anti-tumor medications. Heterocyclic compounds are also used as sanitizers, developers, antioxidants, corrosion inhibitors, copolymers, and dyestuffs. In particular, nitrogen-containing heterocycles represent a highly important class of compounds that are widely used in materials science and medicinal chemistry. ${ }^{1-8}$ They generally show superior pharmaceutical effects compared to non-nitrogen analogues. N-Heterocyclic compounds are constituents of many biologically important molecules, including many vitamins, nucleic acids, pharmaceuticals, antibiotics, dyes, and agrochemicals. ${ }^{9-12}$ In addition, nitrogen-containing heterocycles play a significant role in coordination chemistry. ${ }^{13}$

Among various nitrogen-containing heterocycles, pyrimidine derivatives constitute an interesting subclass. They are present in many natural products, such as vitamin $B_{1}$ (thiamine), and many interesting synthetic compounds, such as barbituric acid and veronal, which are used as hypnotic agents. ${ }^{14,15}$ They demonstrated a wide variety of biological properties, including antibacterial ${ }^{15-17}$, antifungal ${ }^{15,18}$, antileishmanial ${ }^{19}$, antiinflammatory ${ }^{20}$, analgesic ${ }^{21}$, antihypertensive ${ }^{22,23}$, antipyretic ${ }^{24}$, antiviral ${ }^{25}$, antidiabetic ${ }^{26}$, antiallergic ${ }^{27}$, antioxidant ${ }^{28,29}$, antihistaminic ${ }^{30}$, herbicidal ${ }^{31}$, and anticancer activities ${ }^{32,33}$.

Uracil is a very important representative of the pyrimidines. It is one of the five nucleobases and constitutes a promising structure in widespread natural products ${ }^{34}$. Uracil derivatives are interesting molecules in the area of drug discovery ${ }^{35}$ since they exhibit significant pharmacological applications as antiviral ${ }^{36}$, anticancer, cytotoxic $^{37}$, antimycobacterial ${ }^{38}$, anti-inflammatory ${ }^{39}$, antitumor ${ }^{34,40}$, and antibacterial ${ }^{41}$. Moreover, some uracil derivatives showed antithrombotic ${ }^{42}$, antidotal ${ }^{43}$ and potent inhibitors of interleukin-8-induced neutrophil chemotaxis ${ }^{44}$. Some uracils, particularly 6-aminouracils and their corresponding thiouracil derivatives, have been widely used as starting materials for the synthesis of a huge number of biologically important nitrogen-containing heterocycles ${ }^{45-48}$.

In continuation of our interest in reviewing various synthetic approaches to heterocyclic systems, this review highlights various synthetic methods used for the preparation of different heterocyclic systems utilizing aminouracil and aminothiouracil as versatile precursors. Depending on the size of the heterocyclic ring as well as the location and number of heteroatoms, heterocyclic compounds mentioned are arranged in this review. The review will cover the literature in this field from 2015-2020. A few of the recent reviews ${ }^{49-56}$ on this subject appear not to have paid sufficient attention to fused uracil systems in an ordered manner with respect to the ring system. 


\section{Synthesis of Aminouracil and Aminothiouracil}

Two strategies have been described for the synthesis of 6-aminouracil 3. The first one includes the amination of 6 -chlorouracil $\mathbf{2 a}$ or 6 -bromouracil $\mathbf{2} \mathbf{b}$ upon treatment with aqueous ammonia. The second strategy depends mainly on the reduction of the corresponding 6-nitrouracil 1 with different reducing agents (Scheme 1). ${ }^{57-62}$

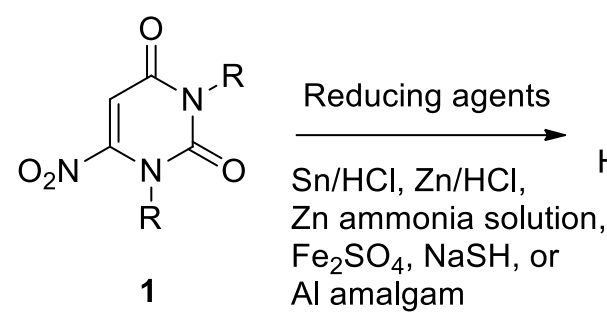<smiles>[R]n1c(N)cc(=O)n([R])c1=O</smiles>

$$
\begin{aligned}
\text { 3a; } R & =H \\
\text { b; } R & =M e \\
\text { c; } R & =P h
\end{aligned}
$$<smiles>[X]c1cc(=O)n([R])c(=O)n1[R]</smiles>

2a; $\mathrm{X}=\mathrm{Cl}$

b; $\mathrm{X}=\mathrm{Br}$

Scheme 1. Synthesis of 6-aminouracils 3a-c.

The most common method described for the synthesis of 6-aminothiouracil was the reaction of thiourea (4) with ethyl cyanoacetate (5) in the presence of sodium ethoxide in ethanol at reflux. ${ }^{63,64}$

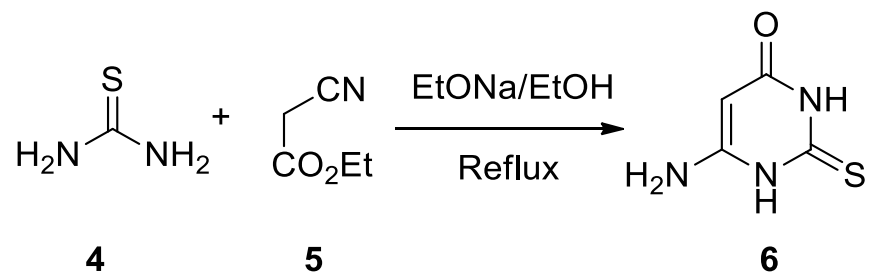

Scheme 2. Synthesis of 6-aminothiouracil 6.

\section{Synthesis of Heterocyclic Compounds using aminouracil and Aminothiouracil}

\subsection{Synthesis of substituted aminouracil (thiouracil) derivatives}

These uracil derivatives have been prepared by direct alkylation reactions.

3.1.1 $\mathrm{N}$-Alkylation reaction. 2,4-Dimethylbenzo[ $d][1,3,6]$ oxadiazepine (7) was reacted with 6-aminothiouracil (6) under acidic conditions through nucleophilic substitution reaction to give compound $\mathbf{8}$ in $80 \%$ yield. The biological cytotoxic activity of compound $\mathbf{8}$ was studied using an in vitro Ehrlich ascites assay ${ }^{65}$ which showed a moderate cytotoxic effect (Scheme 3). ${ }^{66}$

A nucleophilic amination of isothiochromeno[3,4- $d$ ]pyrimidin-1-one 9 with aminothiouracil (6) in dioxane at reflux afforded isothiochromeno[3,4-d]pyrimidin-1-yl)amino)-2-thioxo-2,3-dihydro pyrimidin-4(1H)-one 10 in $55 \%$ yield (Scheme 4). ${ }^{67}$ 


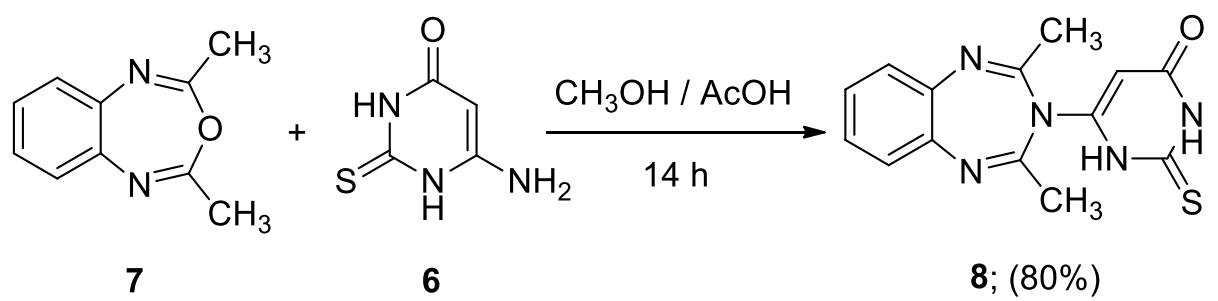

Scheme 3. Synthesis of 6-(2,4-dimethyl-3H-benzo[f][1,3,5]triazepin-3-yl)-2-thioxo-2,3-dihydropyrimidin-4(1H)one (8).<smiles>Cc1nc(Cl)c2c(n1)SC(c1ccncc1)C1=C2C(=Cc2ccncc2)CCC1</smiles>

9<smiles>Nc1cc(=O)[nH]c(=S)[nH]1</smiles><smiles>Cc1nc(Nc2cc(=O)[nH]c(=S)[nH]2)c2c(n1)SC(c1ccncc1)C1=C2C(=Cc2ccncc2)CCC1</smiles>

10; $(55 \%)$

Scheme 4. Synthesis of isothiochromeno[3,4-d]pyrimidin-1-yl)amino)-2-thioxo-2,3-dihydro pyrimidin-4(1H)one 10.

2-Thioxo(1,2,3,6-tetrahydropyrimidin-4-yl)benzo[1,2-b:5,4- $b$ ]difuran-2-carboxamide 12a and 12b were prepared in $88 \%$ and $85 \%$ yield, respectively, through reaction of 6-amino-2-thiouracil (6) with benzo[1,2$b: 5,4-b$ ] difuran-2-carboxylic acid 11a and 11b in DMF at reflux and in the presence of anhydrous potassium carbonate (Scheme 5). ${ }^{68}$<smiles>[R]c1c2occc2c(OC)c2c(C)c(C(=O)O)oc12</smiles>

11a; $\mathrm{R}=\mathrm{H}, \quad(88 \%)$

b; $\mathrm{R}=\mathrm{OCH}_{3},(85 \%)$

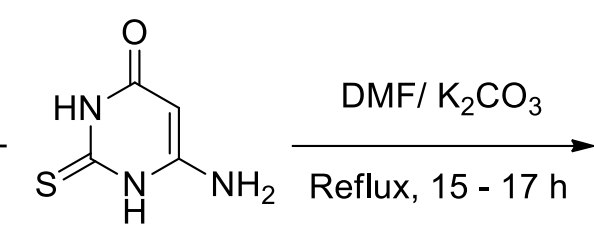

6<smiles>[R]c1c2occc2c(OC)c2c(C)c(C(=O)Nc3cc(=O)[nH]c(=S)[nH]3)oc12</smiles>

12a; $\mathrm{R}=\mathrm{H},(88 \%)$

b; $\mathrm{R}=\mathrm{OCH}_{3},(85 \%)$

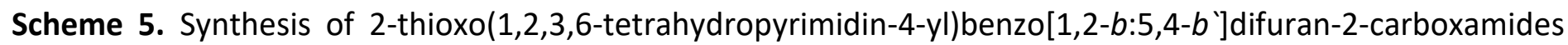
$12 \mathrm{a}$ and $12 \mathrm{~b}$.

3.1.2 S-Alkylation reaction. Gao et al. 69 reported the synthesis of 6-amino-2-(benzylthio)-5thiocyanatopyrimidin-4-ol 14 in 83\% yield upon the reaction of 6-aminothiouracil (6) with benzyl bromide (13) in the presence of sodium hydroxide followed by treatment with potassium thiocyanate in a mixture of pyridine and bromine in DMF (Scheme 6). 
<smiles>Cc1ccccc1</smiles>

Scheme 6. Synthesis of 6-amino-2-(benzylthio)-5-thiocyanatopyrimidin-4-ol (14).

$\mathrm{N}$-(4-Acetylphenyl)-2-((4-amino-6-hydroxypyrimidin-2-yl)thio)acetamide (16) was synthesized in 81\% yield by the reaction of 6-aminothiouracil (6) with $\mathrm{N}$-(4-acetylphenyl)-2-chloroacetamide (15) in acetone in the presence of potassium carbonate as a catalyst (Scheme 7$).{ }^{70}$<smiles>CCC(=O)Nc1ccc(C(C)=O)cc1</smiles>

15

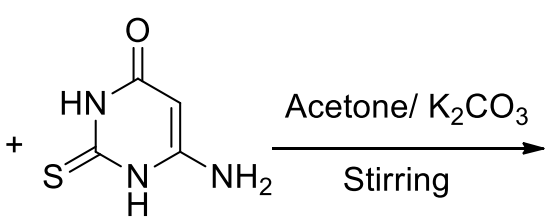

6<smiles>CC(=O)c1ccc(NC(=O)CSc2nc(N)cc(O)n2)cc1</smiles>

16; $(81 \%)$

Scheme 7. Synthesis of N-(4-acetylphenyl)-2-((4-amino-6-hydroxypyrimidin-2-yl)thio) acetamide (16).

Yan et al. $^{71}$ reported the synthesis of 2-((4-amino-6-oxo-1,6-dihydropyrimidin-2-yl)thio)- $N$-(4phenylthiazol-2-yl)acetamide (18) in $86 \%$ yield through the direct alkylation reaction of $N$-(4-acetyl phenyl)-2chloroacetamide (17) with 6-aminothiouracil (16) under basic condition (Scheme 8).

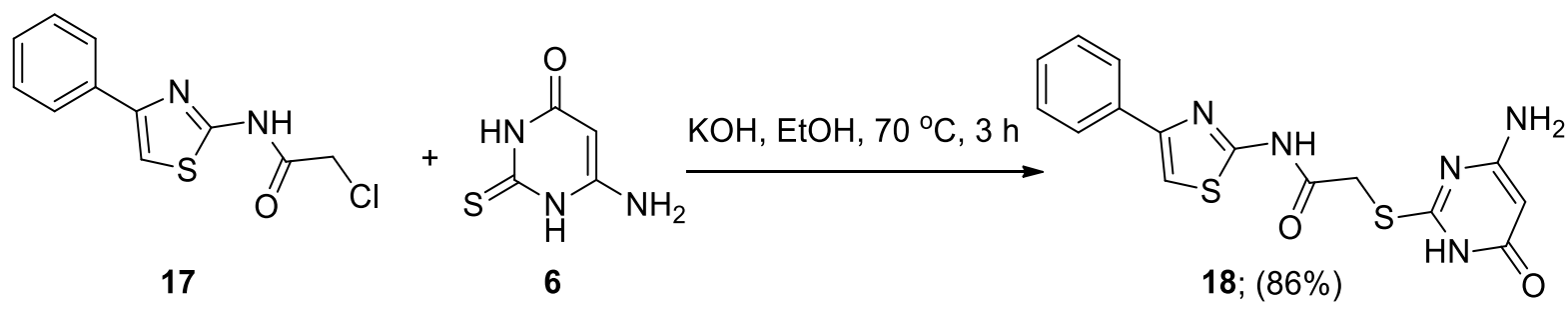

Scheme 8. Synthesis of 2-((4-amino-6-oxo-1,6-dihydropyrimidin-2-yl)thio)-N-(4-phenylthiazol-2-yl)acetamide (18) .

Ibrahim et al. ${ }^{72}$ reported the synthesis of 2-[(4-amino-6-oxo-1,6-dihydropyrimidin-2-yl)thio]- $N$-[6(aminosulfonyl)-1,3-benzothiazol-2-yl]acetamide (20) in 53\% yield through S-alkylation of 2-chloro- $N$-(6sulfamoylbenzo[d] thiazol-2-yl)acetamide (19) with 6-aminothiouracil (6) in DMF and in the presence of $\mathrm{K}_{2} \mathrm{CO}_{3}$. The biological activity of compound $\mathbf{2 0}$ was investigated as an inhibitor of different metalloenzymes of carbonic anhydrase CA I and II, IX, and XII. Compound $\mathbf{2 0}$ was found to exhibit a moderate inhibition effect towards CAll and CA XII compared to the other isoforms (Scheme 9). 
<smiles>Nc1cc(=O)[nH]c(SCC(=O)Nc2nc3ccc(S(N)(=O)=O)cc3s2)n1</smiles>

Scheme 9. Synthesis of 2-[(4-amino-6-oxo-1,6-dihydropyrimidin-2-yl)thio]-N-[6-(aminosulfonyl)-1,3benzothiazol-2-yl]acetamide (20) .

3.1.3 C-Alkylation reaction. Zhang et al. ${ }^{73}$ reported that the reaction of aminouracil derivatives $3 a$ and 6 with 4-methylbenzaldehyde (21) and 1-methyl-4-(2-nitrovinyl)benzene (22) using a recoverable carbonaceous acid $\left(\mathrm{C}-\mathrm{SO}_{3} \mathrm{H}\right)$ as a green catalyst afforded the substituted aminopyrimidin-2,4 diones 23a and 23b rather than the expected pyrido[2,3- $d$ ] pyrimidine $\mathbf{2 4}$ (Scheme 10).

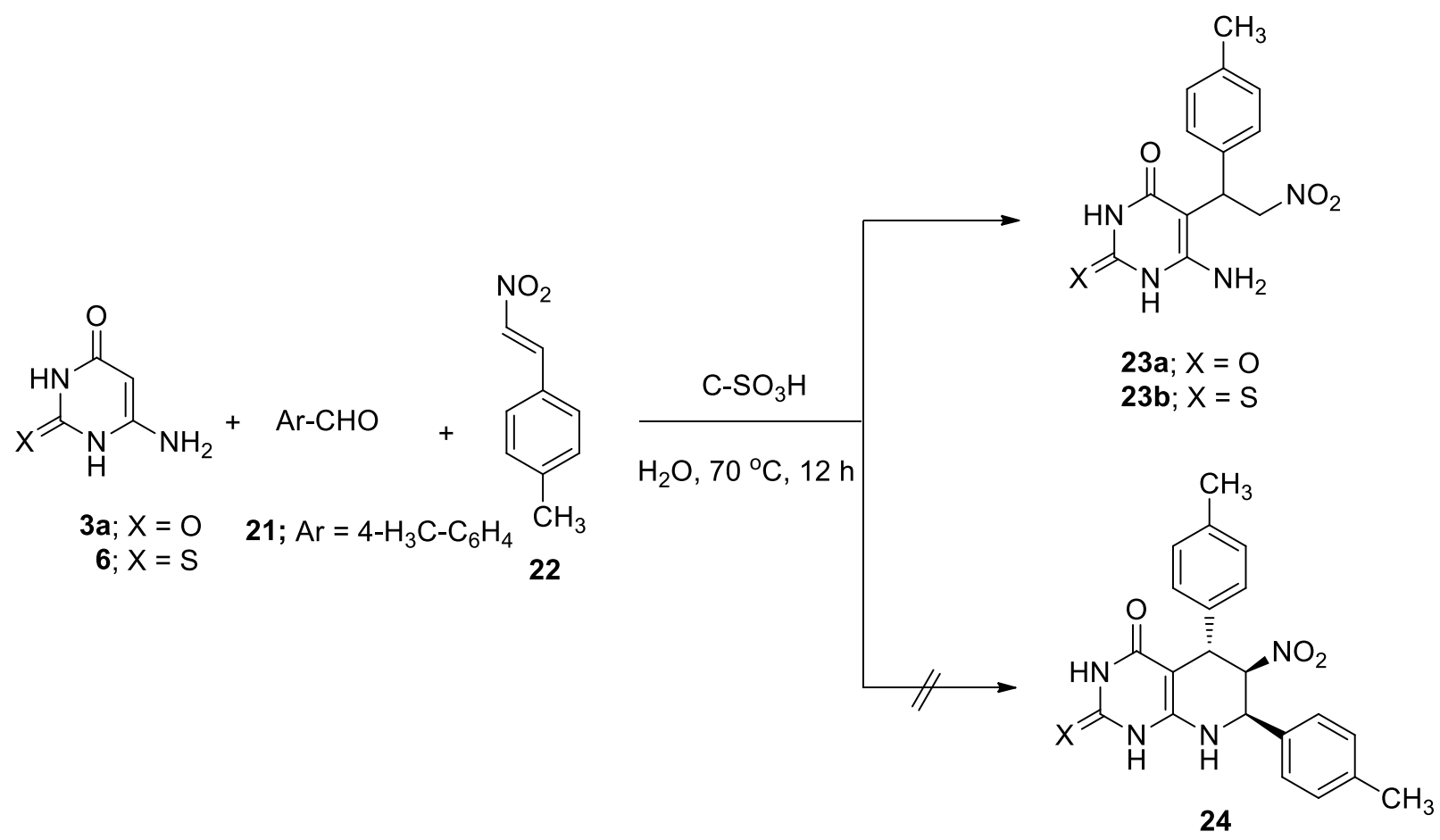

Scheme 10. Synthesis of 6-amino-5-(2-nitro-1-( $p$-tolyl)ethyl)-2,3-dihydropyrimidin-4(1H)-one derivatives 23 a and 23b.

Brahmachari et al. ${ }^{74}$ developed a convenient green method for the preparation of 5-((indol-3-yl) (aryl)methyl)-6-aminopyrimidinediones 24a-w through a multi-component reaction of aryl aldehydes 21 with 6-aminouracil derivatives $\mathbf{3}$ and $\mathbf{6}$ and indoles 25 under acidic condition (Scheme 11, Table 1). 


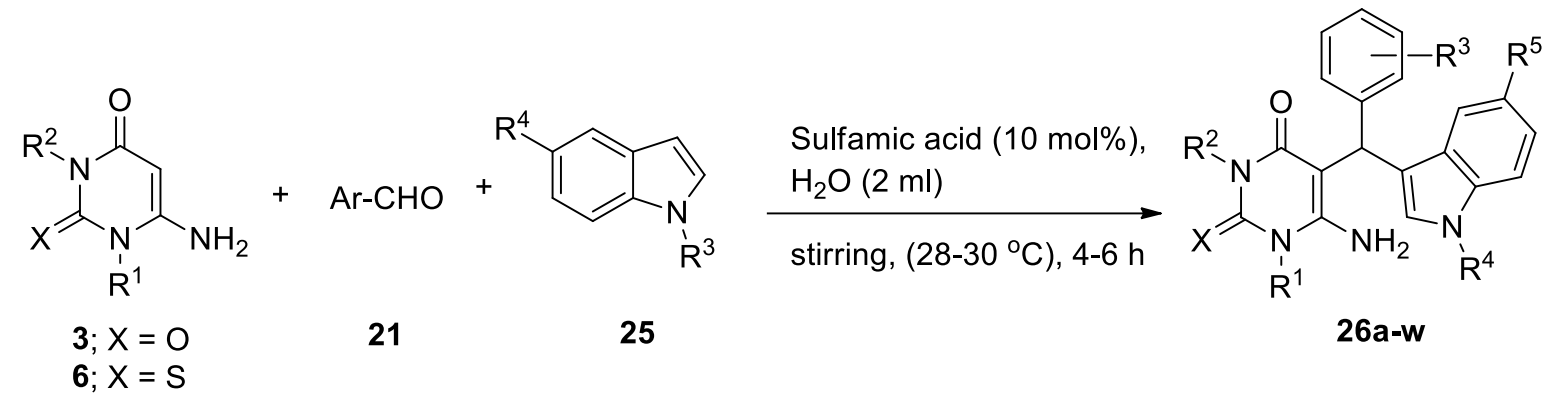

Scheme 11. Synthesis of 5-((1H-indol-3-yl)(aryl)methyl)-6-aminopyrimidinediones and 6-amino-2-mercapto-5((1-methyl-1H-indol-3-yl)(aryl)methyl)pyrimidinediones 26a-w.

Table 1. \% Yields of compounds 26a-w

\begin{tabular}{|c|c|c|c|c|c|c|c|}
\hline Products & $\mathrm{R}^{1}$ & $R^{2}$ & $\mathrm{R}^{3}$ & $\mathrm{R}^{4}$ & $\mathrm{Ar}$ & $x$ & Yield\% \\
\hline a & $\mathrm{H}$ & $\mathrm{H}$ & $\mathrm{H}$ & $\mathrm{H}$ & $\mathrm{C}_{6} \mathrm{H}_{5}$ & 0 & 89 \\
\hline b & $\mathrm{H}$ & $\mathrm{H}$ & $\mathrm{H}$ & $\mathrm{NO}_{2}$ & $\mathrm{C}_{6} \mathrm{H}_{5}$ & 0 & 97 \\
\hline c & $\mathrm{CH}_{3}$ & $\mathrm{H}$ & $\mathrm{H}$ & $\mathrm{NO}_{2}$ & $\mathrm{C}_{6} \mathrm{H}_{5}$ & 0 & 80 \\
\hline d & $\mathrm{CH}_{3}$ & $\mathrm{H}$ & $\mathrm{H}$ & $\mathrm{OCH}_{3}$ & $\mathrm{C}_{6} \mathrm{H}_{5}$ & 0 & 89 \\
\hline e & $\mathrm{H}$ & $\mathrm{H}$ & $\mathrm{H}$ & $\mathrm{OCH}_{3}$ & $4-\mathrm{H}_{3} \mathrm{C}-\mathrm{C}_{6} \mathrm{H}_{4}$ & 0 & 97 \\
\hline$f$ & $\mathrm{CH}_{3}$ & $\mathrm{H}$ & $\mathrm{H}$ & $\mathrm{OCH}_{3}$ & $4-\mathrm{H}_{3} \mathrm{C}-\mathrm{C}_{6} \mathrm{H}_{4}$ & $\mathrm{O}$ & 95 \\
\hline g & $\mathrm{H}$ & $\mathrm{H}$ & $\mathrm{H}$ & $\mathrm{H}$ & $4-\mathrm{H}_{3} \mathrm{CO}-\mathrm{C}_{6} \mathrm{H}_{4}$ & $\mathrm{O}$ & 82 \\
\hline h & $\mathrm{H}$ & $\mathrm{H}$ & $\mathrm{H}$ & $\mathrm{OCH}_{3}$ & $4-\mathrm{H}_{3} \mathrm{CO}-\mathrm{C}_{6} \mathrm{H}_{4}$ & 0 & 96 \\
\hline $\mathbf{i}$ & $\mathrm{H}$ & $\mathrm{H}$ & $\mathrm{H}$ & $\mathrm{NO}_{2}$ & $4-\mathrm{H}_{3} \mathrm{CO}-\mathrm{C}_{6} \mathrm{H}_{4}$ & 0 & 92 \\
\hline $\mathrm{j}$ & $\mathrm{H}$ & $\mathrm{H}$ & $\mathrm{H}$ & $\mathrm{H}$ & $4-\mathrm{O}_{2} \mathrm{~N}-\mathrm{C}_{6} \mathrm{H}_{4}$ & 0 & 91 \\
\hline k & $\mathrm{CH}_{3}$ & $\mathrm{H}$ & $\mathrm{H}$ & $\mathrm{H}$ & $4-\mathrm{O}_{2} \mathrm{~N}-\mathrm{C}_{6} \mathrm{H}_{4}$ & 0 & 97 \\
\hline 1 & $\mathrm{CH}_{3}$ & $\mathrm{CH}_{3}$ & $\mathrm{H}$ & $\mathrm{H}$ & $4-\mathrm{O}_{2} \mathrm{~N}-\mathrm{C}_{6} \mathrm{H}_{4}$ & 0 & 96 \\
\hline m & $\mathrm{H}$ & $\mathrm{H}$ & $\mathrm{H}$ & $\mathrm{NO}_{2}$ & $4-\mathrm{O}_{2} \mathrm{~N}-\mathrm{C}_{6} \mathrm{H}_{4}$ & $\mathrm{O}$ & 94 \\
\hline $\mathbf{n}$ & $\mathrm{H}$ & $\mathrm{H}$ & $\mathrm{H}$ & $\mathrm{NO}_{2}$ & $4-\mathrm{F}-\mathrm{C}_{6} \mathrm{H}_{4}$ & $\mathrm{O}$ & 60 \\
\hline $\mathbf{0}$ & $\mathrm{CH}_{3}$ & $\mathrm{H}$ & $\mathrm{H}$ & $\mathrm{F}$ & $2-\mathrm{F}-\mathrm{C}_{6} \mathrm{H}_{4}$ & $\mathrm{O}$ & 95 \\
\hline p & $\mathrm{H}$ & $\mathrm{H}$ & $\mathrm{CH}_{3}$ & $\mathrm{H}$ & $3-\mathrm{Cl}-\mathrm{C}_{6} \mathrm{H}_{4}$ & 0 & 91 \\
\hline$q$ & H & $\mathrm{H}$ & $\mathrm{H}$ & $\mathrm{H}$ & $3-\mathrm{Br}-\mathrm{C}_{6} \mathrm{H}_{4}$ & 0 & 90 \\
\hline$r$ & $\mathrm{H}$ & $\mathrm{H}$ & $\mathrm{H}$ & $\mathrm{OCH}_{3}$ & $3-\mathrm{Br}-\mathrm{C}_{6} \mathrm{H}_{4}$ & 0 & 96 \\
\hline$s$ & $\mathrm{H}$ & $\mathrm{H}$ & $\mathrm{H}$ & $\mathrm{H}$ & 4-NC- $\mathrm{C}_{6} \mathrm{H}_{4}$ & $\mathrm{O}$ & 95 \\
\hline $\mathbf{t}$ & $\mathrm{H}$ & $\mathrm{H}$ & $\mathrm{H}$ & $\mathrm{H}$ & $4-\left(\mathrm{CH}_{3}\right)_{2} \mathrm{~N}-\mathrm{C}_{6} \mathrm{H}_{4}$ & 0 & 96 \\
\hline $\mathbf{u}$ & $\mathrm{H}$ & $\mathrm{H}$ & $\mathrm{H}$ & $\mathrm{Br}$ & $2-\mathrm{HOOC}-\mathrm{C}_{6} \mathrm{H}_{4}$ & 0 & 51 \\
\hline $\mathbf{v}$ & $\mathrm{H}$ & $\mathrm{H}$ & $\mathrm{H}$ & $\mathrm{H}$ & $\mathrm{C}_{6} \mathrm{H}_{5}$ & $\mathrm{~S}$ & 96 \\
\hline w & $\mathrm{H}$ & $\mathrm{H}$ & $\mathrm{H}$ & $\mathrm{H}$ & $4-\mathrm{F}_{3} \mathrm{C}-\mathrm{C}_{6} \mathrm{H}_{4}$ & $\mathrm{~S}$ & 95 \\
\hline
\end{tabular}

A series of substituted 6-amino-5-((4-hydroxy-2-oxo-2H-chromen-3-yl)(aryl)methyl)pyrimidine-2,4$(1 \mathrm{H}, 3 \mathrm{H})$-diones 28a-t was synthesized via a one-pot reaction of aryl aldehydes 21, 4-hydroxycoumarin (27), and 6-aminouracil derivatives $\mathbf{3}$ using sulfamic acid as an eco-friendly solid acid-catalyst in aqueous ethanol and under ultrasound irradiation as a green synthetic protocol (Scheme 12, Table 2). ${ }^{75}$ 


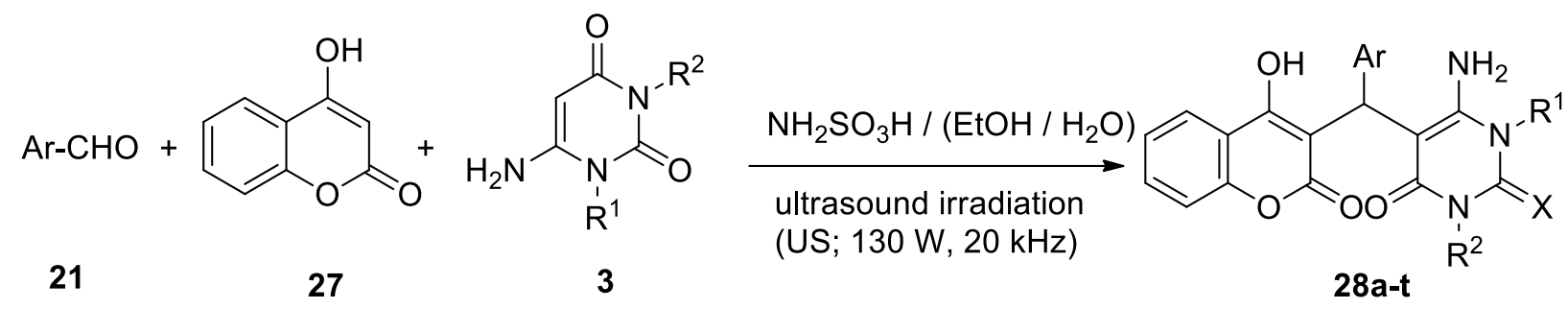

Scheme 12. Synthesis of 6-amino-5-((4- hydroxy-2-oxo-2H-chromen-3- yl)(aryl)methyl) pyrimidine-2,4-(1H,3H)diones 28a-t.

Table 2. \% Yields of compounds 28a-t

\begin{tabular}{|c|c|c|c|c|}
\hline Products & $\mathrm{R}^{1}$ & $\mathrm{R}^{2}$ & $\mathrm{Ar}$ & Yield\% \\
\hline a & $\mathrm{H}$ & $\mathrm{H}$ & $\mathrm{C}_{6} \mathrm{H}_{5}$ & 83 \\
\hline b & $\mathrm{H}$ & $\mathrm{H}$ & $3-\mathrm{Br}-\mathrm{C}_{6} \mathrm{H}_{4}$ & 86 \\
\hline c & $\mathrm{H}$ & $\mathrm{H}$ & $4-\mathrm{F}-\mathrm{C}_{6} \mathrm{H}_{4}$ & 95 \\
\hline d & $\mathrm{H}$ & $\mathrm{H}$ & 4-NC- $\mathrm{C}_{6} \mathrm{H}_{4}$ & 93 \\
\hline e & $\mathrm{H}$ & $\mathrm{H}$ & $4-\mathrm{F}_{3} \mathrm{C}-\mathrm{C}_{6} \mathrm{H}_{4}$ & 91 \\
\hline$f$ & $\mathrm{H}$ & $\mathrm{H}$ & $4-\mathrm{OHC}-\mathrm{C}_{6} \mathrm{H}_{4}$ & 92 \\
\hline g & $\mathrm{H}$ & $\mathrm{H}$ & $4-\mathrm{H}_{3} \mathrm{C}-\mathrm{C}_{6} \mathrm{H}_{4}$ & 98 \\
\hline h & $\mathrm{H}$ & $\mathrm{H}$ & $4-\mathrm{H}_{3} \mathrm{CO}-\mathrm{C}_{6} \mathrm{H}_{4}$ & 98 \\
\hline $\mathbf{i}$ & $\mathrm{H}$ & $\mathrm{H}$ & $3-\mathrm{CH}_{3} \mathrm{O}-4-\mathrm{HO}-\mathrm{C}_{6} \mathrm{H}_{3}$ & 87 \\
\hline $\mathbf{j}$ & $\mathrm{H}$ & $\mathrm{H}$ & $3,4-\left(\mathrm{O}-\mathrm{CH}_{2}-\mathrm{O}\right)-\mathrm{C}_{6} \mathrm{H}_{3}$ & 93 \\
\hline k & $\mathrm{CH}_{3}$ & $\mathrm{H}$ & $\mathrm{C}_{6} \mathrm{H}_{5}$ & 98 \\
\hline I & $\mathrm{CH}_{3}$ & $\mathrm{H}$ & $3-\mathrm{H}_{3} \mathrm{C}-\mathrm{C}_{6} \mathrm{H}_{4}$ & 96 \\
\hline m & $\mathrm{CH}_{3}$ & $\mathrm{H}$ & $4-\mathrm{H}_{3} \mathrm{CO}-\mathrm{C}_{6} \mathrm{H}_{4}$ & 98 \\
\hline $\mathbf{n}$ & $\mathrm{CH}_{3}$ & $\mathrm{H}$ & $3,4-\left(\mathrm{H}_{3} \mathrm{CO}\right)_{2}-\mathrm{C}_{6} \mathrm{H}_{3}$ & 81 \\
\hline $\mathbf{0}$ & $\mathrm{CH}_{3}$ & $\mathrm{H}$ & $3,4,5-\left(\mathrm{H}_{3} \mathrm{CO}\right)_{3}-\mathrm{C}_{6} \mathrm{H}_{3}$ & 95 \\
\hline $\mathbf{p}$ & $\mathrm{CH}_{3}$ & $\mathrm{CH}_{3}$ & $\mathrm{C}_{6} \mathrm{H}_{5}$ & 94 \\
\hline $\mathbf{q}$ & $\mathrm{CH}_{3}$ & $\mathrm{CH}_{3}$ & $4-\mathrm{H}_{3} \mathrm{C}-\mathrm{C}_{6} \mathrm{H}_{4}$ & 97 \\
\hline$r$ & $\mathrm{CH}_{3}$ & $\mathrm{CH}_{3}$ & $4-\mathrm{H}_{3} \mathrm{CO}-3-\mathrm{HO}-\mathrm{C}_{6} \mathrm{H}_{3}$ & 91 \\
\hline $\mathbf{s}$ & $\mathrm{CH}_{3}$ & $\mathrm{CH}_{3}$ & $3-\mathrm{H}_{3} \mathrm{CO}-4-\mathrm{HO}-\mathrm{C}_{6} \mathrm{H}_{3}$ & 97 \\
\hline $\mathbf{t}$ & $\mathrm{CH}_{3}$ & $\mathrm{CH}_{3}$ & $3,4-\left(\mathrm{H}_{3} \mathrm{CO}\right)_{2}-\mathrm{C}_{6} \mathrm{H}_{3}$ & 80 \\
\hline
\end{tabular}

Abdelmoniem et $a l .{ }^{76}$ reported that the reaction of the appropriate bis(aldehydes) 29a-h with 4 equivalents of 6-aminouracil (3) in acetic acid at reflux gave the tetrakis(6-aminopyrimidine-2,4(1H,3H)-dione) derivatives 30a-h in a good yields (Scheme 13). 


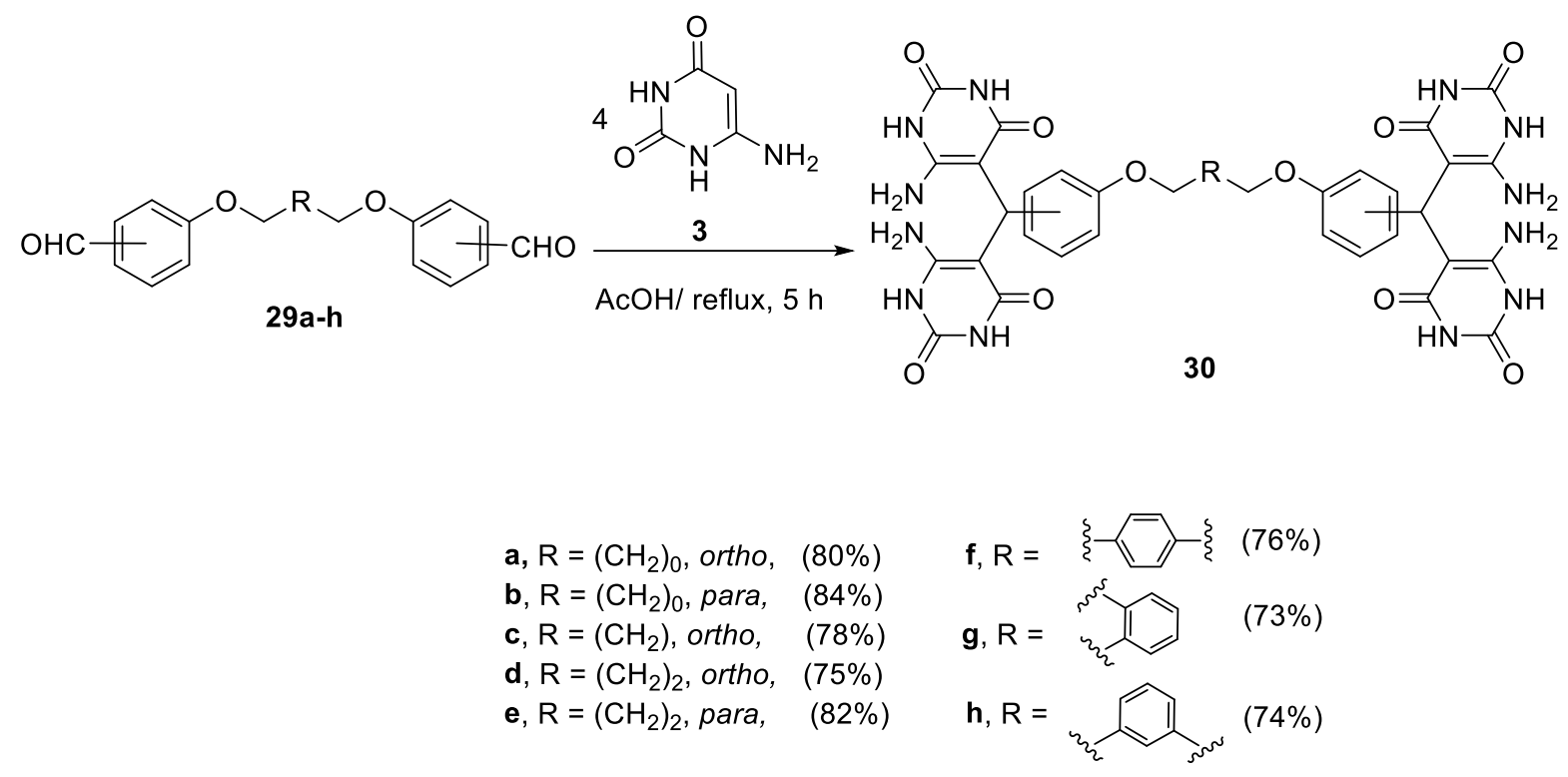

Scheme 13. Synthesis of tetrakis(6-aminopyrimidine-2,4(1H,3H)-dione) derivatives 30a-h.

\subsection{Synthesis of uracil-fused heterocycles}

3.2.1 Synthesis of fused bicyclic systems. 3.2.1.1 Fused [5-6]systems: Three heteroatoms. 3.2.1.1.1 Synthesis of pyrrolo[2,3- $d$ ]pyrimidines. Li et al. ${ }^{77}$ revealed the synthesis of pyrrolo[2,3- $d$ ]pyrimidin-4-ones 32a-f via reaction of nitroolefins $\mathbf{3 1}$ with 6-aminopyrimidinedione derivatives $\mathbf{3}$ or $\mathbf{6}$ using L-proline as an acid catalyst (Scheme 14, Table 3).<smiles></smiles>

$$
\begin{aligned}
& 3 ; X=0 \\
& 6 ; X=S
\end{aligned}
$$<smiles>C/C(=C/Br)[N+](=O)[O-]</smiles><smiles></smiles>

32a-f

Scheme 14. Synthesis of pyrrolo[2,3-d]pyrimidin-4-ones 32a-f.

Table 3. \% Yields of compounds 32a-f

\begin{tabular}{cccc}
\hline Products & $\mathrm{Ar}$ & $\mathrm{X}$ & Yield\% \\
\hline $\mathbf{a}$ & $4-\mathrm{F}-\mathrm{C}_{6} \mathrm{H}_{4}$ & $\mathrm{O}$ & $71 \%$ \\
b & $4-\mathrm{Cl}-\mathrm{C}_{6} \mathrm{H}_{4}$ & $\mathrm{O}$ & $65 \%$ \\
c & $4-\mathrm{Br}_{-} \mathrm{C}_{6} \mathrm{H}_{4}$ & $\mathrm{O}$ & $61 \%$ \\
d & $\mathrm{C}_{6} \mathrm{H}_{5}$ & $\mathrm{~S}$ & $71 \%$ \\
e & $4-\mathrm{F}-\mathrm{C}_{6} \mathrm{H}_{4}$ & $\mathrm{~S}$ & $73 \%$ \\
$\mathbf{f}$ & $4-\mathrm{H}_{3} \mathrm{C}-\mathrm{C}_{6} \mathrm{H}_{4}$ & $\mathrm{~S}$ & $54 \%$ \\
\hline
\end{tabular}

Bayat et $a .^{78}$ reported a free catalytic approach for regioselective synthesis of pyrrolo[2,3-d]pyrimidine derivatives 35a-k instead of the expected pentaaza-cyclopenta[b]naphthalen-5-ones $\mathbf{3 6}$ through a three 
component reaction of 3-methyl-2-pyrazoline-5-one derivatives 33a-c, arylglyoxal 34, and 6-aminouracil derivatives 3 or 6 in ethanol at reflux (Scheme 15, Table 4).

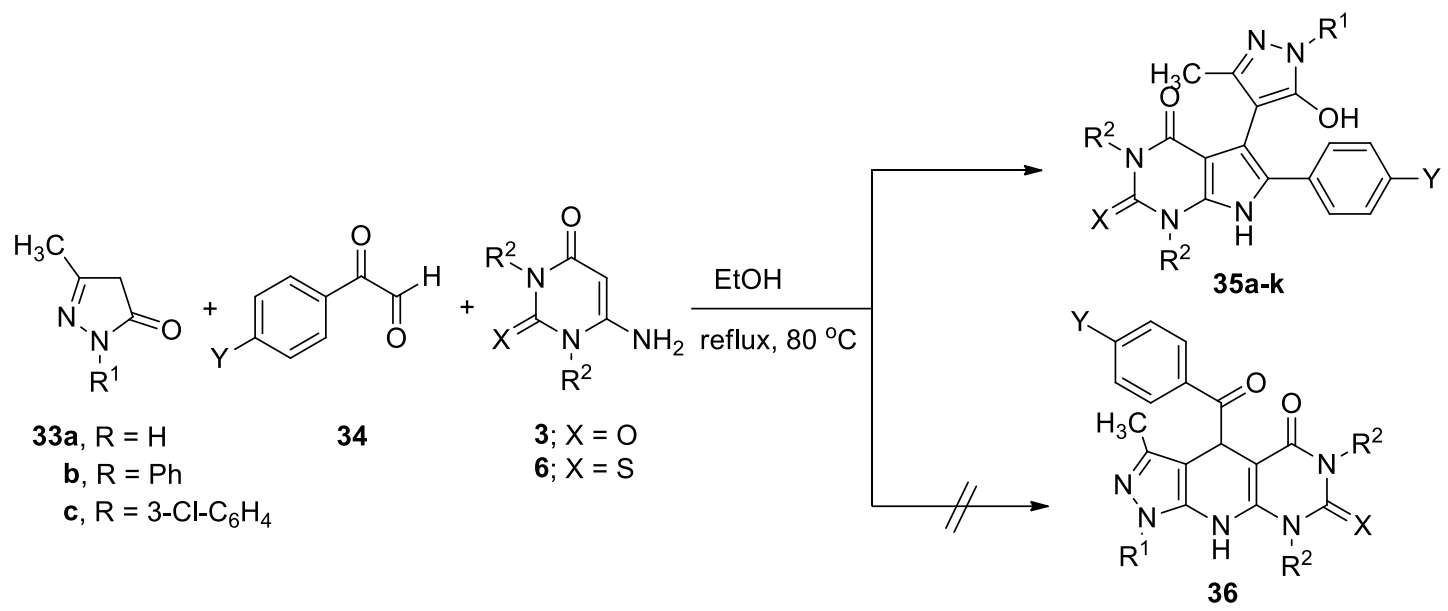

Scheme 15. Synthesis of pyrrolo[2,3-d]pyrimidine derivatives 35a-k.

Table 4. \% Yields of compounds 35a-k

\begin{tabular}{cccccc}
\hline Products & $\mathrm{R}^{1}$ & $\mathrm{R}^{2}$ & $\mathrm{Y}$ & $\mathrm{X}$ & Yield\% \\
\hline $\mathbf{a}$ & $\mathrm{C}_{6} \mathrm{H}_{5}$ & $\mathrm{H}$ & $\mathrm{H}$ & $\mathrm{S}$ & 95 \\
$\mathbf{b}$ & $\mathrm{C}_{6} \mathrm{H}_{5}$ & $\mathrm{H}$ & $\mathrm{F}$ & $\mathrm{S}$ & 80 \\
$\mathbf{c}$ & $3-\mathrm{Cl}_{-} \mathrm{C}_{6} \mathrm{H}_{4}$ & $\mathrm{H}$ & $\mathrm{H}$ & $\mathrm{S}$ & 98 \\
$\mathbf{d}$ & $3-\mathrm{Cl}-\mathrm{C}_{6} \mathrm{H}_{4}$ & $\mathrm{H}$ & $\mathrm{F}$ & $\mathrm{S}$ & 83 \\
$\mathbf{e}$ & $2-\mathrm{Cl}-\mathrm{C}_{6} \mathrm{H}_{4}$ & $\mathrm{H}$ & $\mathrm{F}$ & $\mathrm{S}$ & 85 \\
$\mathbf{f}$ & $\mathrm{H}$ & $\mathrm{H}$ & $\mathrm{H}$ & $\mathrm{S}$ & 82 \\
$\mathbf{g}$ & $\mathrm{C}_{6} \mathrm{H}_{5}$ & $\mathrm{CH}_{3}$ & $\mathrm{H}$ & $\mathrm{O}$ & 92 \\
$\mathbf{h}$ & $\mathrm{C}_{6} \mathrm{H}_{5}$ & $\mathrm{CH}_{3}$ & $\mathrm{~F}$ & $\mathrm{O}$ & 85 \\
$\mathbf{i}$ & $3-\mathrm{Cl}_{6}-\mathrm{C}_{6} \mathrm{H}_{4}$ & $\mathrm{CH}_{3}$ & $\mathrm{H}$ & $\mathrm{O}$ & 98 \\
$\mathbf{j}$ & $3-\mathrm{Cl}-\mathrm{C}_{6} \mathrm{H}_{4}$ & $\mathrm{CH}_{3}$ & $\mathrm{~F}$ & $\mathrm{O}$ & 89 \\
$\mathbf{k}$ & $\mathrm{H}$ & $\mathrm{CH}_{3}$ & $\mathrm{H}$ & 0 & 80 \\
\hline
\end{tabular}

A series of pyrrolo[2,3- $d$ ] pyrimidine derivatives 39a-g were prepared in good yields through a one-pot reaction of arylglyoxal hydrate $\mathbf{3 8}$ with aminouracil derivatives $\mathbf{3}$ or $\mathbf{6}$ and barbituric acid $\mathbf{3 7}$. However, the reaction was carried out using different conditions, the best result was achieved using used ethanol as solvent at reflux (Scheme 16, Table 5). ${ }^{79}$ 
<smiles></smiles>
3; $X=0$
6; $X=S$
37
38
39a-g

Scheme 16. Synthesis of pyrrolo[2,3-d]pyrimidine derivatives 39a-g.

Table 5. \% Yields of compounds 39a-g

\begin{tabular}{cccccc}
\hline Products & $\mathrm{R}^{1}$ & $\mathrm{R}^{2}$ & $\mathrm{R}^{3}$ & $\mathrm{X}$ & Yield\% \\
\hline $\mathbf{a}$ & $\mathrm{CH}_{3}$ & $\mathrm{H}$ & $\mathrm{CH}_{3}$ & $\mathrm{O}$ & 88 \\
$\mathbf{b}$ & $\mathrm{H}$ & $\mathrm{H}$ & $\mathrm{CH}_{3}$ & $\mathrm{O}$ & 86 \\
$\mathbf{c}$ & $\mathrm{CH}_{3}$ & $\mathrm{OCH}_{3}$ & $\mathrm{H}$ & $\mathrm{O}$ & 79 \\
$\mathbf{d}$ & $\mathrm{H}$ & $\mathrm{OCH}_{3}$ & $\mathrm{CH}_{3}$ & $\mathrm{O}$ & 84 \\
$\mathbf{e}$ & $\mathrm{CH}_{3}$ & $\mathrm{H}$ & $\mathrm{H}$ & $\mathrm{S}$ & 76 \\
$\mathbf{f}$ & $\mathrm{CH}_{3}$ & $\mathrm{Br}$ & $\mathrm{H}$ & $\mathrm{S}$ & 82 \\
$\mathbf{g}$ & $\mathrm{H}$ & $\mathrm{Br}$ & $\mathrm{H}$ & $\mathrm{S}$ & 74 \\
\hline
\end{tabular}

Sabegh et al. ${ }^{80}$ reported the synthesis of bis-pyrrolo[2,3-d]pyrimidine derivatives $41 \mathrm{a}-\mathrm{g}$ and $43 \mathrm{3a-e}$ through a multicomponent reaction of 1,4-phenylene-bis-glyoxal (40) with 6-aminouracil derivatives $\mathbf{3}$ or $\mathbf{6}$ and either barbituric acid $\mathbf{3 7}$ or dimedone (42) (Scheme 17, Table 6).

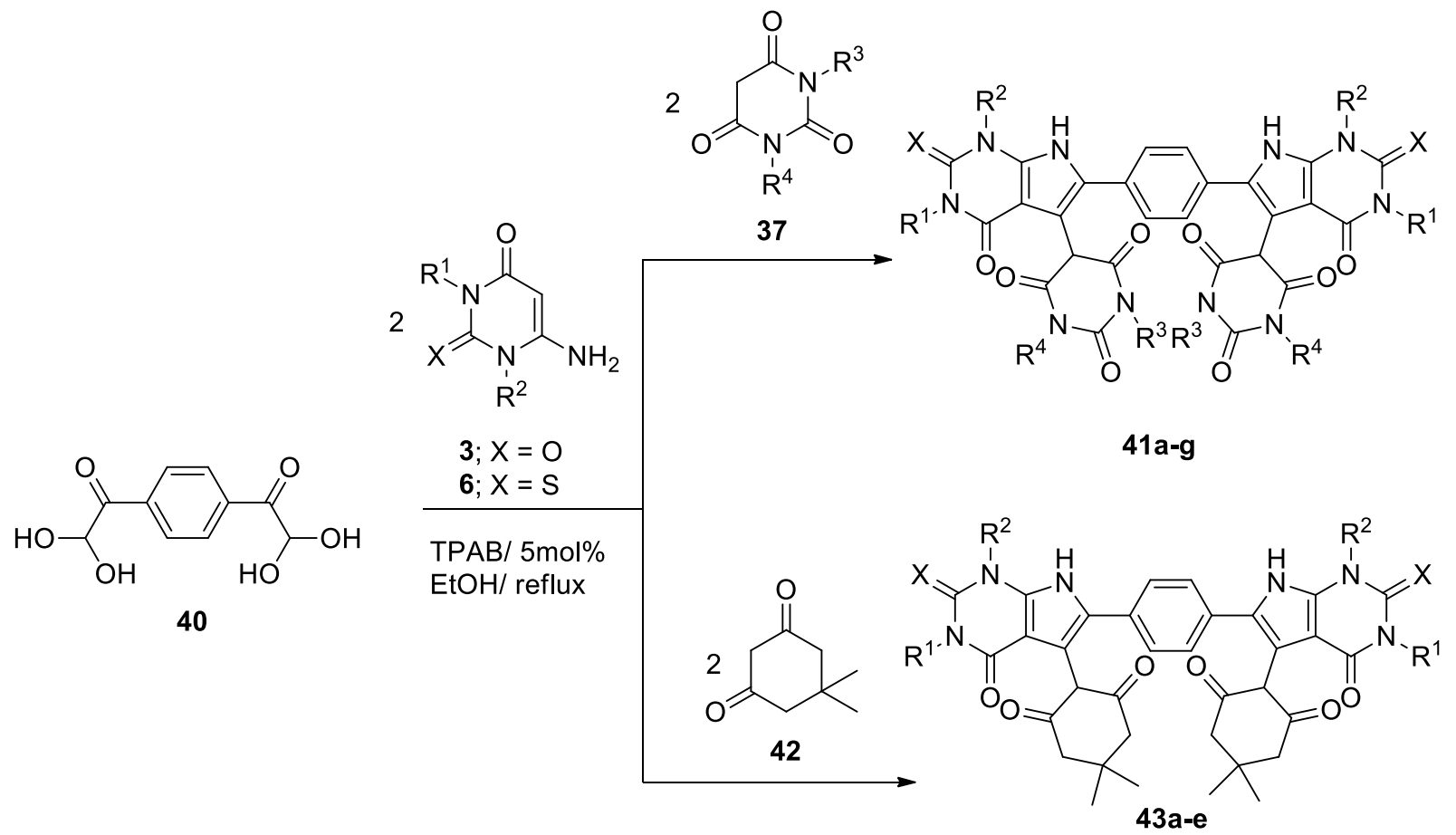

Scheme 17. Synthesis of bis-pyrrolo[2,3-d]pyrimidine derivatives 41a-g and 43a-e. 
Table 6. \% Yields of compounds 41a-g and 43a-e

\begin{tabular}{ccccccc}
\hline Products & $\mathrm{R}^{1}$ & $\mathrm{R}^{2}$ & $\mathrm{R}^{3}$ & $\mathrm{R}^{4}$ & $\mathrm{X}$ & Yield\% \\
\hline 41a & $\mathrm{H}$ & $\mathrm{H}$ & $\mathrm{H}$ & $\mathrm{H}$ & $\mathrm{O}$ & 95 \\
41b & $\mathrm{H}$ & $\mathrm{H}$ & $\mathrm{CH}_{3}$ & $\mathrm{CH}_{3}$ & $\mathrm{O}$ & 96 \\
41c & $\mathrm{H}$ & $\mathrm{CH}_{3}$ & $\mathrm{H}$ & $\mathrm{H}$ & $\mathrm{O}$ & 96 \\
41d & $\mathrm{H}$ & $\mathrm{CH}_{3}$ & $\mathrm{CH}_{3}$ & $\mathrm{CH}_{3}$ & $\mathrm{O}$ & 94 \\
41e & $\mathrm{CH}_{3}$ & $\mathrm{CH}_{3}$ & $\mathrm{CH}_{3}$ & $\mathrm{CH}_{3}$ & $\mathrm{O}$ & 95 \\
41f & $\mathrm{CH}_{2} \mathrm{CH}_{3}$ & $\mathrm{CH}_{2} \mathrm{CH}_{3}$ & $\mathrm{CH}_{3}$ & $\mathrm{CH}_{3}$ & $\mathrm{O}$ & 92 \\
41g & $\mathrm{H}$ & $\mathrm{H}$ & $\mathrm{CH}_{3}$ & $\mathrm{CH}_{3}$ & $\mathrm{~S}$ & 93 \\
43a & $\mathrm{H}$ & $\mathrm{H}$ & - & - & $\mathrm{O}$ & 93 \\
43b & $\mathrm{H}$ & $\mathrm{CH}_{3}$ & - & - & $\mathrm{O}$ & 95 \\
43c & $\mathrm{CH}$ & $\mathrm{CH}_{3}$ & - & - & $\mathrm{O}$ & 92 \\
43d & $\mathrm{CH}_{2} \mathrm{CH}_{3}$ & $\mathrm{CH}_{2} \mathrm{CH}_{3}$ & - & - & 0 & 90 \\
43e & $\mathrm{H}$ & $\mathrm{H}$ & - & - & $\mathrm{S}$ & 94 \\
\hline
\end{tabular}

3.2.1.1.2 Synthesis of thiazolo[3,2-a]pyrimidine. The reaction of 6-amino-2-thiouracil (6) with 3-bromoprop-1ene (44) in the presence of $\mathrm{KOH}$ in aqueous ethanol gave firstly, the corresponding $S$-alkyl derivatives. Subsequent treatment of the latter compound with either iodine or bromine in acetic acid afforded thiazolo[3,2-a]pyrimidin-4-ium halides 45 and 46 in $45 \%$ and 30\% yield, respectively (Scheme 18). ${ }^{81}$<smiles>Nc1cc(=O)[nH]c(=S)[nH]1</smiles>

1) $\mathrm{CH}_{2}=\mathrm{CHCH}_{2} \mathrm{Br}, \mathrm{KOH}, \mathrm{EtOH}$

2) $\mathrm{Br}_{2}$ or $\left(\mathrm{I}_{2} / \mathrm{Nal}\right)$, acetone, $\mathrm{AcOH}$<smiles>[X]CC1CSc2[nH]c(=O)c([Y])c(N)[n+]21</smiles>

45; $X=\mathrm{I} ; \quad \mathrm{Y}=\mathrm{H} ; \quad(45 \%)$ 46; $X=\mathrm{Br} ; \mathrm{Y}=\mathrm{Br} ;(30 \%)$

Scheme 18. Synthesis of thiazolo[3,2-a]pyrimidin-4-ium halides 45 and 46.

Thiazolo[3,2-a]pyrimidin-5-ones 51a-f were obtained in good yields via reaction of the appropriately substituted phenacyl halides $\mathbf{5 0}$ with 6-substituted anilino-2-thiouracil $\mathbf{4 9}$ (prepared from the reaction of 6amino-2-thiouracil (6) with substituted anilines 47 in the presence of aniline hydrochloride 48 at high temperature) in the presence of anhydrous potassium carbonate followed by cyclization upon heating with conc. $\mathrm{H}_{2} \mathrm{SO}_{4}$. Compounds $\mathbf{5 1 a - f}$ were reported to display significant antibacterial inhibitory activities against Mycobacterium smegmatis (Scheme 19, Table 7). ${ }^{82}$ 
<smiles>[R]c1ccc(N)cc1</smiles>

47

48

6

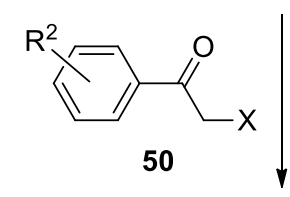

1) $\mathrm{DMF} / \mathrm{K}_{2} \mathrm{CO}_{3}$

2) Conc. $\mathrm{H}_{2} \mathrm{SO}_{4}$ $20^{\circ} \mathrm{C}$ or $80^{\circ} \mathrm{C}$

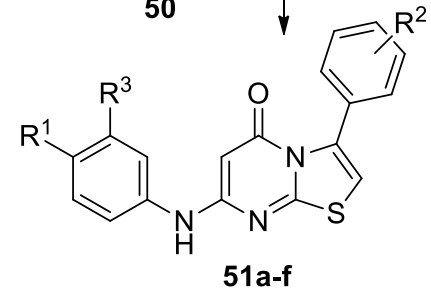

Scheme 19. Synthesis of thiazolo[3,2-a]pyrimidin-5-ones 51a-f.

Table 7. \% Yields of compounds 51a-f

\begin{tabular}{ccccc}
\hline Products & $\mathrm{R}^{1}$ & $\mathrm{R}^{2}$ & $\mathrm{R}^{3}$ & Yield\% \\
\hline $\mathbf{a}$ & $\mathrm{SO}_{3} \mathrm{H}$ & $3-\mathrm{NO}_{2}$ & $\mathrm{H}$ & 92 \\
b & $\mathrm{SO}_{3} \mathrm{H}$ & $4-\mathrm{NO}_{2}$ & $\mathrm{H}$ & 92 \\
c & $\mathrm{CH}_{3}$ & $3-\mathrm{NO}_{2}$ & $\mathrm{SO}_{3} \mathrm{H}$ & 91 \\
d & $\mathrm{CH}_{3}$ & $4-\mathrm{NO}_{2}$ & $\mathrm{SO}_{3} \mathrm{H}$ & 89 \\
e & $\mathrm{OCH}_{3}$ & $3-\mathrm{NO}_{2}$ & $\mathrm{SO}_{3} \mathrm{H}$ & 79 \\
f & $\mathrm{OCH}_{3}$ & $4-\mathrm{NO}_{2}$ & $\mathrm{SO}_{3} \mathrm{H}$ & 80 \\
\hline
\end{tabular}

Thiazolo[3,2-a]pyrimidin-7-ylbenzo[1,2-b:5,4- $b^{\prime}$ ]difuran-2-carboxamides 53a and 53b were synthesized in $84 \%$ and $85 \%$ yields, respectively, upon reaction of 2-thioxo-1,2,3,6-tetrahydro pyrimidin-4-yl)benzo[1,2- $b: 5,4-$ $b^{\prime}$ ]difuran-2-carboxamide $\mathbf{1 2 a}$ and $\mathbf{1 2 b}$, respectively, with chloroacetic acid $\mathbf{5 2}$ in a mixture of glacial acetic acid/acetic anhydride and anhydrous sodium acetate. Thiazolopyrimidines $\mathbf{5 3 a}$ and $\mathbf{5 3 \mathbf { b }}$ were found to display a high inhibition effect on cyclooxygenase enzyme (COX). Besides, the same compounds were reported to possess high anti-inflammatory activities expressed in a significant reduction in interleukin-1 beta (IL-1 $\beta$ ) concentration (Scheme 20). ${ }^{68}$<smiles>[R]c1c2occc2c(OC)c2c(C)c(C(=O)Nc3cc(=O)[nH]c(=S)[nH]3)oc12</smiles>

12a; $\mathrm{R}=\mathrm{H}$

b; $\mathrm{R}=\mathrm{OCH}_{3}$

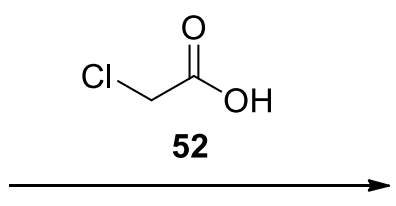

$\mathrm{AcOH}, \mathrm{Ac}_{2} \mathrm{O}, \mathrm{AcONa}$ $14-16 \mathrm{~h}, 80-90^{\circ} \mathrm{C}$<smiles>[R]c1c2occc2c(OC)c2c(C)c(C(=O)Nc3cc(=O)n4c(n3)SCC4=O)oc12</smiles>

53a; $\mathrm{R}=\mathrm{H}, \quad(84 \%)$

b; $\mathrm{R}=\mathrm{OCH}_{3},(85 \%)$

Scheme 20. Synthesis of thiazolo[3,2-a]pyrimidin-7-ylbenzo[1,2-b:5,4- $b$ `] difuran-2-carboxamides 53a and 53b. 
3.2.1.2. Fused [5-6]systems: Four heteroatoms. 3.2.1.2.1. Synthesis of thiazolo[4,5-d]pyrimidine. A series of thiazolo[4,5-d]pyrimidine derivatives 54a-I were synthesized in 38-51\% yield, via a cyclocondensation of 6amino-2-(benzylthio)-5-thiocyanatopyrimidin-4-ol (14) in DMF at reflux followed by treatment with $\mathrm{POCl}_{3}$ in $N, N$-dimethylaniline, and subsequent reaction with the appropriate secondary amine (Scheme 21, Table 8).

The anti-cancer activity of thiazolo[4,5-d]pyrimidine derivatives 54a-I was studied against colorectal cancer by testing its inhibitory effect on PAK4 (p21-activated kinase 4). It was found that all compounds have a potential PAK4 (p21-activated kinase 4) inhibitory effect. In particular, compound 54j revealed the highest inhibitory effect among the tested compounds. ${ }^{83}$<smiles>Nc1nc(SCc2ccccc2)nc(O)c1S(N)(=O)=O</smiles>

14
1) DMF, $\mathrm{H}_{2} \mathrm{O}, 110^{\circ} \mathrm{C}, 10 \mathrm{~h}$

2) $\mathrm{POCl}_{3}, N, N$-Dimethylaniline, $100^{\circ} \mathrm{C}$

3) DIPEA, NMP, $\mathrm{R}^{1} \mathrm{R}^{2} \mathrm{NH}, 110^{\circ} \mathrm{C}, 6 \mathrm{~h}$<smiles>[R14]N([R])c1nc(SCc2ccccc2)nc2nc(N)sc12</smiles>

Scheme 21. Synthesis of 2-amino-5-(benzylthio)thiazolo[4,5-d]pyrimidin-7-ols.

Table 8. Synthesis of compounds 54a-I

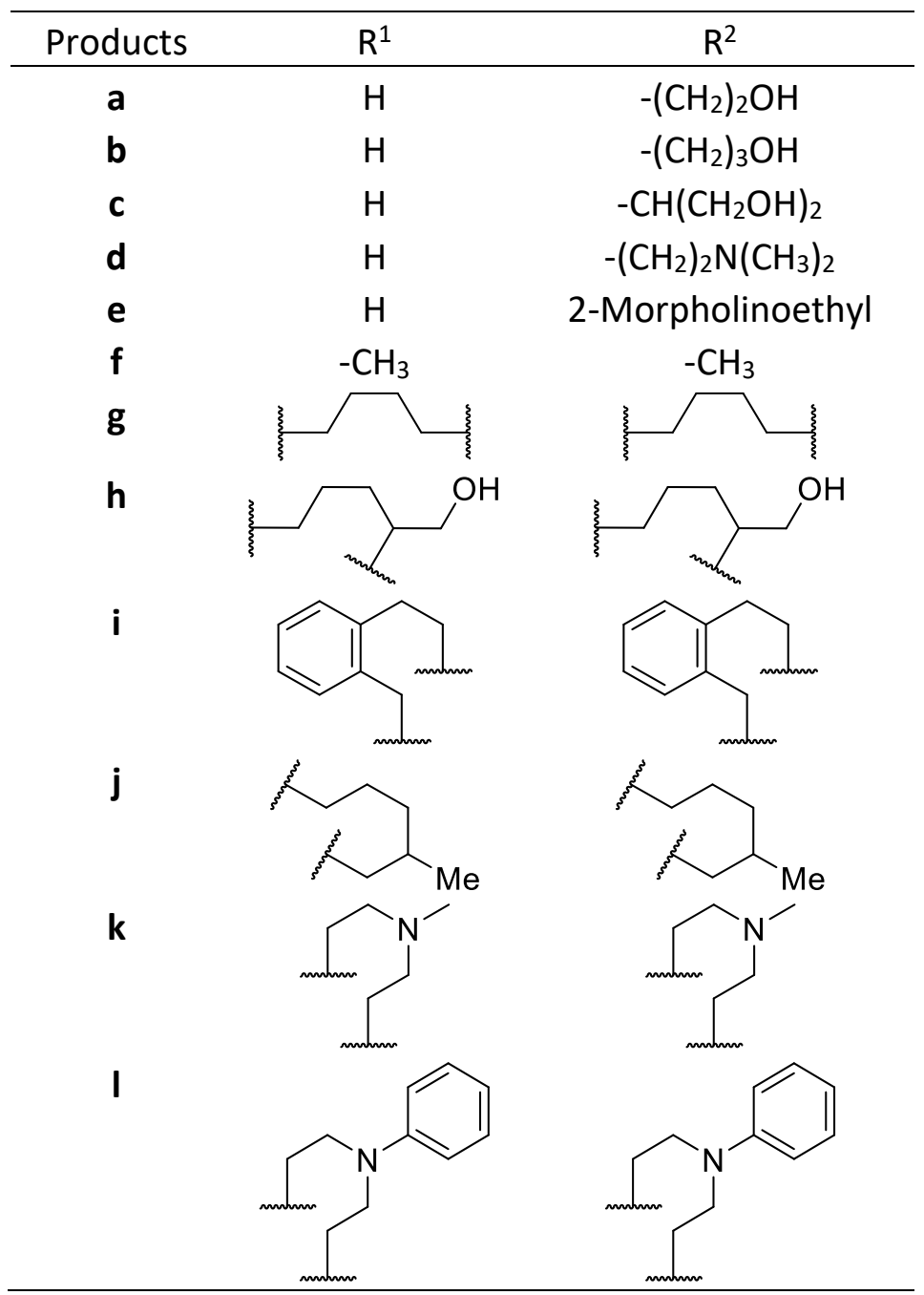


3.2.1.2.2. Synthesis of triazolo[4,3-a]pyrimidine. 7-Amino-3-phenyl[1,2,4]triazolo[4,3-a]pyrimidin-5(1H)-one (57) was prepared through two distinct paths, using either 6-aminothiouracil (6) or 6-amino-2(methylthio)pyrimidin-4(3H)-one (55) (prepared by the action of methyl iodide on 6 in ethanolic potassium hydroxide solution). Upon reacting one of the latter compounds with benzohydrazide (56) in DMF/ EtOH mixture followed by stirring at reflux in sodium ethoxide, compound $\mathbf{5 7}$ was obtained in $\mathbf{7 5 \%}$ yield (Scheme 22). ${ }^{84}$

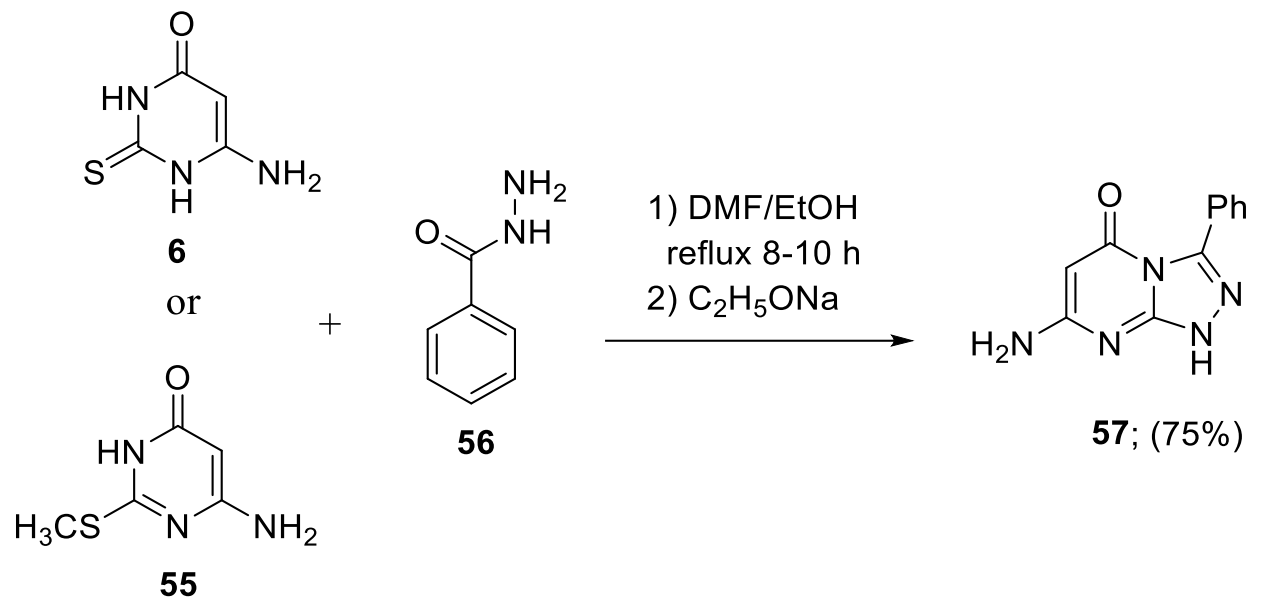

Scheme 22. Synthesis of 7-Amino-3-phenyl[1,2,4]triazolo[4,3-a]pyrimidin-5(1H)-one (57).

3.2.1.3. Fused [6-6]systems: Three heteroatoms. 3.2.1.3.1. Synthesis of pyrido[2,3-d]pyrimidine. Reaction of 6-aminothiouracil (6) with acetylacetone (58) in triflouroacetic acid gave 5,7-dimethyl-2-thioxo-2,3dihydropyrido[2,3-d]pyrimidin-4(1H)-one (59) in 96\% yield (Scheme 23). ${ }^{85}$<smiles>CC(=O)CC(C)(C)C(=O)O</smiles>

Scheme 23. Synthesis of 5,7-dimethyl-2-thioxo-2,3-dihydropyrido[2,3-d]pyrimidin-4(1H)-one (59).

Mamaghani et al. ${ }^{86}$ reported the synthesis of hexahydropyrido[2,3-d]pyrimidine derivatives 61a-i through the reaction of 3-(6-amino-4-oxo-2-thioxo-1,2,3,4-tetrahydropyrimidin-5-yl)-3-oxopropanenitrile (60) with aromatic aldehydes $\mathbf{2 1}$ at reflux in DMF using heterogeneous nanocatalyst. Compound $\mathbf{6 0}$ was obtained upon the reaction of 6-aminouracil (6) with cyanoacetic acid in acetic anhydride (Scheme 24, Table 9).<smiles>N#CCC(=O)OCC(=O)OCC(=O)O</smiles>

6<smiles>N#CCC(=O)c1c(N)[nH]c(=S)[nH]c1=O</smiles>

60<smiles>N#Cc1c(Br)[nH]c2[nH]c(=S)[nH]c(=O)c2c1=O</smiles>

$61 a-i$

Scheme 24. Synthesis of hexahydropyrido[2,3-d]pyrimidine derivatives 61a-i. 
Table 9. \% Yields of compounds 61a-i

\begin{tabular}{|c|c|c|}
\hline Products & $\mathrm{Ar}=$ & Yield\% \\
\hline a & 4-Cl- $\mathrm{C}_{6} \mathrm{H}_{4}$ & 96 \\
\hline b & $4-\mathrm{F}-\mathrm{C}_{6} \mathrm{H}_{4}$ & 96 \\
\hline c & 2-Thienyl & 87 \\
\hline d & 3-Pyridyl & 84 \\
\hline e & $2-\mathrm{HO}-\mathrm{C}_{6} \mathrm{H}_{4}$ & 84 \\
\hline$f$ & 2-Naphthyl & 85 \\
\hline g & $-\left(\mathrm{CH}_{2}\right)_{2}-\mathrm{C}_{6} \mathrm{H}_{5}$ & 87 \\
\hline h & 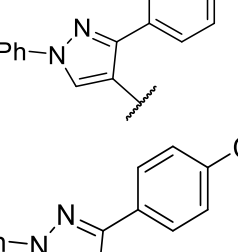 & $\begin{array}{l}84 \\
86\end{array}$ \\
\hline
\end{tabular}

Some aminouracil derivatives 3 and 6 reacted with a variety of chalcones 62 under different conditions to give pyrido[2,3-d]pyrimidines 63 successfully in good yields. It is worth mentioning that some of the reported compounds in (Table 10) have shown various bioactivities.

Fares et al. ${ }^{87}$ reported that some of the synthesized pyrido[2,3- $d$ ]pyrimidine derivatives displayed antimicrobial and anti-fungal activities. Among the tested derivatives, compound $63\left(\mathrm{R}^{1}=4-\mathrm{Cl}_{-}-\mathrm{C}_{6} \mathrm{H}_{4}, \mathrm{R}^{2}=\mathrm{C}_{6} \mathrm{H}_{5}\right)$ was found to exhibit the most potent effect against Streptococcus pneumoniae and Escherichia coli. On the other hand, compounds $63\left(\mathrm{R}^{1}=4-\mathrm{Cl}-\mathrm{C}_{6} \mathrm{H}_{4}, \mathrm{R}^{2}=4-\mathrm{H}_{3} \mathrm{CO}-\mathrm{C}_{6} \mathrm{H}_{4}\right),\left(\mathrm{R}^{1}=2\right.$-Thienyl, $\left.\mathrm{R}^{2}=4-\mathrm{F}-\mathrm{C}_{6} \mathrm{H}_{4}\right)$ and $\left(\mathrm{R}^{1}=2-\mathrm{Thienyl}, \mathrm{R}^{2}=\right.$ $4-\mathrm{H}_{3} \mathrm{CO}-\mathrm{C}_{6} \mathrm{H}_{4}$ ) were reported to have the most active anti-fungal agents against Aspergillus fumigatus. Otherwise, Nassar et al. ${ }^{88}$ reported that pyrido[2,3-d]pyrimidine $63\left(\mathrm{R}^{1}=2\right.$-Thienyl, $\left.\mathrm{R}^{2}=4-\mathrm{H}_{3} \mathrm{CO}-\mathrm{C}_{6} \mathrm{H}_{4}\right)$ showed the most anti-microbial effect against Gram-negative Pseudomonas aeruginosa (Scheme 25, Table 10).<smiles>[R]C=CC([R])=O</smiles>

62

$$
\begin{aligned}
& \text { 3: } X=0 \\
& \text { 6: } X=S
\end{aligned}
$$

63

Method A: Dry DMF, reflux

Method B: $\mathrm{AcOH} /$ grinding, r.t

Method C: $\mathrm{AcOH} /$ reflux

Method D: EtOH/reflux

Scheme 25. Synthesis of pyrido[2,3-d]pyrimidine derivatives 63. 
Table 10. \% Yields of compounds

\begin{tabular}{|c|c|c|c|c|c|}
\hline Method & $\mathrm{R}^{1}$ & $R^{2}$ & $x$ & Yield\% & Ref. \\
\hline A & $\begin{array}{l}\text { 4-Cl- } \mathrm{C}_{6} \mathrm{H}_{4} \\
\text { 2-Thienyl }\end{array}$ & $\begin{array}{c}\left(\mathrm{C}_{6} \mathrm{H}_{5}, 4-\mathrm{F}-\mathrm{C}_{6} \mathrm{H}_{4}, 4-\mathrm{Cl}-\mathrm{C}_{6} \mathrm{H}_{4}\right. \\
4-\mathrm{H}_{3} \mathrm{CO}-\mathrm{C}_{6} \mathrm{H}_{4} \\
\left.4-\mathrm{O}_{2} \mathrm{~N}-\mathrm{C}_{6} \mathrm{H}_{4}\right)\end{array}$ & $S$ & $40-65$ & 87 \\
\hline A & 2-Benzofuranyl & 4-(Piperidin-1-yl)phenyl & $0, \mathrm{~S}$ & $72-75$ & 88 \\
\hline C & 2-Thienyl & 2-Thienyl & $S$ & 76 & 89 \\
\hline C & & $\begin{array}{c}4-\mathrm{F}-\mathrm{C}_{6} \mathrm{H}_{5} \\
2,4-\mathrm{Cl}_{2}-\mathrm{C}_{6} \mathrm{H}_{5}\end{array}$ & $S$ & $75-78$ & 90 \\
\hline B & $\mathrm{Ph}^{\prime}$ & $\mathrm{C}_{6} \mathrm{H}_{5}$ & $S$ & 79 & 91 \\
\hline C & $\mathrm{Ph}$ & $\mathrm{C}_{6} \mathrm{H}_{5}$ & $S$ & 79 & 92 \\
\hline C & $\begin{array}{c}\left(\mathrm{R}^{3}=\mathrm{C}_{6} \mathrm{H}_{5}\right. \\
\left.3,5-(\mathrm{Me})_{2} \mathrm{C}_{6} \mathrm{H}_{3}\right)\end{array}$ & $\mathrm{C}_{6} \mathrm{H}_{5}$ & $S$ & $75-80$ & 93 \\
\hline D & $-\mathrm{NH}^{\prime} \mathrm{H}$ & $\mathrm{C}_{6} \mathrm{H}_{5}$ & $S$ & 70 & 94 \\
\hline A & 3-Pyridyl & $\begin{array}{c}\left(\mathrm{C}_{6} \mathrm{H}_{5}, 3-\mathrm{H}_{3} \mathrm{CO}-\mathrm{C}_{6} \mathrm{H}_{4}\right. \\
\left.2-\mathrm{Br}-\mathrm{C}_{6} \mathrm{H}_{4}\right)\end{array}$ & $S$ & $61-67$ & $95-97$ \\
\hline C & 2-Benzofuranyl & 3-Indolyl & $S$ & 80 & 98 \\
\hline C & 3-Indolyl & $\left(4-\mathrm{H}_{3} \mathrm{C}-\mathrm{C}_{6} \mathrm{H}_{5}, 4-\mathrm{Cl}-\mathrm{C}_{6} \mathrm{H}_{4}\right)$ & $S$ & $72-76$ & 99 \\
\hline
\end{tabular}

Popova et al. ${ }^{100}$ reported that the reaction of benzopyran derivatives $64 a-\mathbf{d}$ with an equimolar ratio of 6amino thiouracil derivatives $\mathbf{3}$ or $\mathbf{6}$ in DMF at reflux gave the corresponding 1,3-dimethyl-7(trifluoromethyl)pyrido[2,3-d]pyrimidine-2,4(1H,3H)-diones 65a-d in moderate yields (Scheme 26, Table 11). 


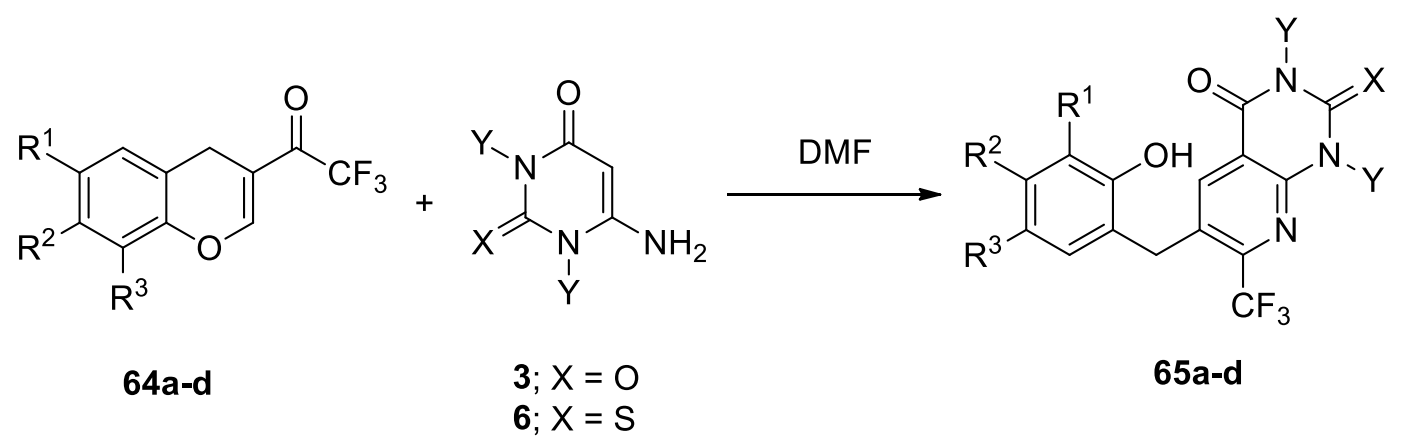

Scheme 26. Synthesis of pyrido[2,3-d] pyrimidine derivatives $65 a-d$.

Table 11. \% Yields of compounds 65a-d

\begin{tabular}{ccccccc}
\hline Products & $\mathrm{R}^{1}$ & $\mathrm{R}^{2}$ & $\mathrm{R}^{3}$ & $\mathrm{X}$ & $\mathrm{Y}$ & Yield\% \\
\hline a & $\begin{array}{c}\text { 1- } \\
\text { Adamantyl }\end{array}$ & $\mathrm{H}$ & $\mathrm{CH}_{3}$ & $\mathrm{O}$ & $\mathrm{CH}_{3}$ & 64 \\
b & $\mathrm{H}$ & $\mathrm{CH}_{3}$ & $\mathrm{CH}_{3}$ & $\mathrm{O}$ & $\mathrm{CH}_{3}$ & 61 \\
c & $\mathrm{H}$ & $\mathrm{H}$ & $\mathrm{NO}_{2}$ & $\mathrm{O}$ & $\mathrm{CH}_{3}$ & 73 \\
d & $\mathrm{H}$ & $\mathrm{CH}_{3}$ & $\mathrm{CH}_{3}$ & $\mathrm{~S}$ & $\mathrm{H}$ & 62 \\
\hline
\end{tabular}

In a similar manner, 2-(hydroxynaphthalen-1-yl)7-(trifluoromethyl)-2,3-dihydropyrido[2,3- $d$ ] pyrimidine$4(1 H)$-one derivatives $67 a-c$ were synthesized in 68,72 and $59 \%$ yields, respectively, by the reaction of aminouracil derivatives 3 or $\mathbf{6}$ with 2-trifluoroacetyl-1H-benzo[f]chromenes 66 (Scheme 27, Table 12). ${ }^{100}$<smiles>[Y][Y4](=O)O[Na]</smiles>

Scheme 27. Synthesis of pyrido[2,3-d]pyrimidine derivatives 67a-c.

Table 12. \% Yields of compounds 67a-c

\begin{tabular}{|c|c|c|c|c|}
\hline Products & $\mathrm{R}^{4}$ & $\mathrm{x}$ & $Y$ & Yield\% \\
\hline$a$ & $\mathrm{H}$ & 0 & $\mathrm{CH}_{3}$ & 68 \\
\hline b & $\begin{array}{c}1- \\
\text { Adamantyl }\end{array}$ & 0 & $\mathrm{CH}_{3}$ & 72 \\
\hline c & $\mathrm{H}$ & $S$ & $\mathrm{H}$ & 59 \\
\hline
\end{tabular}

Treatment of furo[3,2-g]chromene-6-carbaldehyde $\mathbf{6 8}$ with 6-aminouracil derivatives $\mathbf{3}$ or $\mathbf{6}$ led to the formation of pyrido[2,3-d]pyrimidine derivatives $69 \mathrm{a}$ and $69 \mathrm{~b}$, respectively, via ring-opening / ring closure 
reaction in good yield. The synthesized compounds showed high antimicrobial activities against two types of Gram-positive bacteria (Scheme 28). ${ }^{101}$<smiles>COc1c2occc2c(OC)c2c(=O)c(C=O)coc12</smiles>

68<smiles></smiles>

$3 ; X=0$

$6 ; X=S$<smiles></smiles>

69a; $\mathrm{R}^{1}=\mathrm{H}, \mathrm{X}=\mathrm{S} ;(71 \%)$

b; $R^{1}=M e, X=0 ;(67 \%)$

Scheme 28. Synthesis of pyrido[2,3-d]pyrimidine derivatives $69 \mathrm{a}$ and 69b.

Enamine 70 reacted with aminouracils 3 and 6 mostly under acidic conditions to give different derivatives of pyrido[2,3- $d$ ]pyrimidines 71a-c. Compound 71c showed a potent tyrosine kinase inhibition effect when studied as an anti-cancer agent (Scheme 29, Table 13).<smiles></smiles>

70

3; $X=0$

6; $X=S$

71a-c

Scheme 29. Synthesis of pyrido[2,3-d]pyrimidine 71a-c.

Table 13. \% Yields of compounds 71a-c

\begin{tabular}{|c|c|c|c|c|}
\hline Products & $\mathrm{R}$ & $x$ & Yield\% & Ref. \\
\hline a & & $S$ & 90 & 102 \\
\hline b & & $S$ & 83 & 103 \\
\hline C & & $b ; x=S$ & 57-61 & 104 \\
\hline
\end{tabular}

The synthesis of bis(2-thioxo-2,3-dihydropyrido[2,3-d]pyrimidin-4(1H)-one) derivatives 73a-f was performed via a direct reaction of 6-aminothiouracil (6) with bis(enaminones) 72 . The reactions were carried 
out in acetic acid at reflux in the presence of $p$-TSA using conventional heating or microwave irradiation (Scheme 30, Table 14). ${ }^{105}$<smiles>COc1ccccc1C(=O)/C=C/N(C)C</smiles>

72<smiles>C/C=C\Oc1ccccc1-c1ccnc2[nH]c(=S)[nH]c(=O)c12</smiles>

73a-f

Method A; reflux $3 \mathrm{~h}$

Method B; Mw (15 min)

Scheme 30. Synthesis of bis pyrido[2,3-d]pyrimidines 73a-f.

Table 14. \% Yields of compounds 73a-f

\begin{tabular}{ccccc}
\hline \multirow{2}{*}{ Products } & & & \multicolumn{2}{c}{ Yield\% } \\
\cline { 4 - 6 } & & Isomer & A & B \\
\hline a & $-\left(\mathrm{CH}_{2}\right)_{2^{-}}$ & o-isomer & 78 & 81 \\
b & $-\left(\mathrm{CH}_{2}\right)_{2^{-}}$ & $p$-isomer & 82 & 85 \\
d & $-\left(\mathrm{CH}_{2}\right)_{3^{-}}$ & $p$-isomer & 92 & 94 \\
e & $-\left(\mathrm{CH}_{2}\right)_{4^{-}}$ & o-isomer & 73 & 77 \\
$\mathbf{f}$ & $-\left(\mathrm{CH}_{2}\right)_{4^{-}}$ & $p$-isomer & 75 & 80 \\
\hline
\end{tabular}

Fadda et al. ${ }^{106}$ reported the regioselective synthesis of 7-amino-5-(benzo[d]thiazol-2-yl)-2-thioxo-2,3dihydropyrido[2,3-d]pyrimidin-4(1H)-one (75) in 78\% yield by the reaction of 2-(benzo[d]thiazol-2-yl)-3(dimethylamino)acrylonitrile (74) with 6-aminothiouracil (6) in ethanol at reflux in the presence of TEA as a catalyst. The reaction proceeds by the Michael type addition of the most nucleophilic ring carbon, C-5 of uracil, to the activated double bond of the vinyl ketone forming a Michael adduct as an intermediate which underwent a cycloaddition reaction. The authors have not commented on the regioselective formation of compound 75 (Scheme 31).

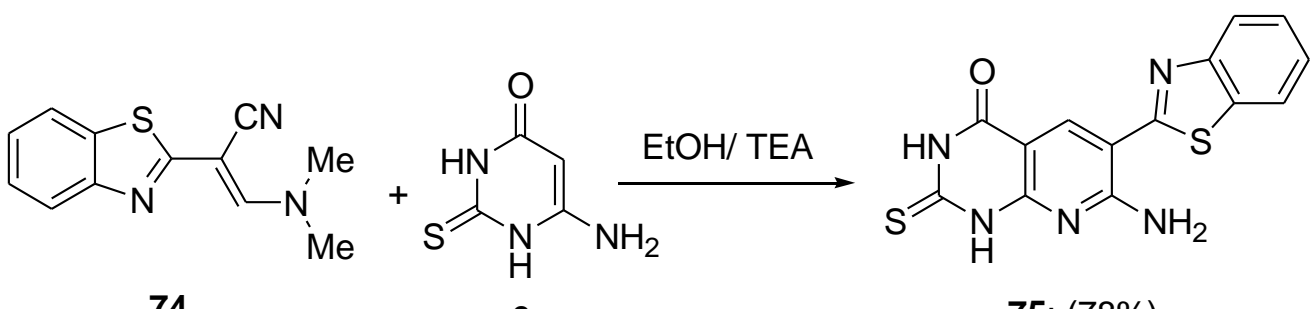

74

6

$75 ;(78 \%)$

Scheme 31. Synthesis of 7-amino-5-(benzo[d]thiazol-2-yl)-2-thioxo-2,3-dihydropyrido[2,3- $d]$ pyrimidin-4(1H)one (75). 
On the other hand, the same authors reported the synthesis of pyrido[2,3-d]pyrimidinone 77 in $62 \%$ yield through the reaction of 6-aminothiouracil (6) with 2-(benzo[d]thiazol-2-yl)-3,3-bis-(methylthio)acrylonitrile (76) in ethanol at reflux and in the presence of piperidine as a basic catalyst. Compound 77 exhibited potent anti-microbial activity against the Gram-positive Bacillus subtilis (Scheme 32). ${ }^{106}$

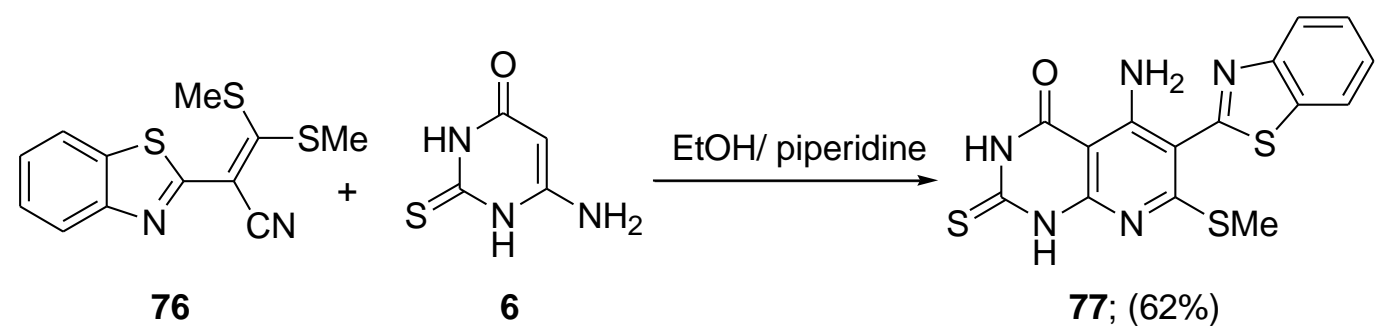

Scheme 32. Synthesis of pyrido[2,3-d]pyrimidine-4-one 77.

The reaction of 3,3-bis(methylthio)-2-(10H-phenothiazine-10-carbonyl)acrylonitrile (78) with 6aminothiouracil (6) in DMF at reflux and in the presence of TEA as a catalyst afforded pyrido[2,3-d] pyrimidin$4(1 H)$-one 79 in $78 \%$ yield (Scheme 33). ${ }^{107}$<smiles>CSC(SC)=C(C#N)C(=O)N1c2ccccc2Sc2ccccc21</smiles>

78<smiles>Nc1cc(=O)[nH]c(=S)[nH]1</smiles>

6

Scheme 33. Synthesis of pyrido[2,3-d] pyrimidin-4(1H)-one 79.

Ohanjanyan et al. ${ }^{108}$ reported the synthesis of dihydropyrido[2,3-d]pyrimidin-4(3H)-ones $80 \mathrm{a}$ and $80 \mathrm{~b}$ in $52 \%$ and $58 \%$ yields, respectively, via a multi-component reaction of 6 -aminothiouracil 3 or 6 with aryl aldehydes 21 and pentane-2,4-dione 58 (Scheme 34, Table 15).

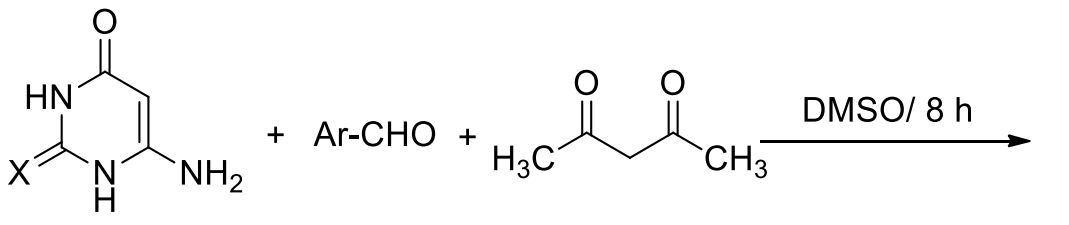

$$
3 ; X=O
$$$$
\text { 6; } X=S
$$

21 58<smiles></smiles>

$80 a, b$

Scheme 34. Synthesis of dihydropyrido[2,3-d]pyrimidin-4(3H)-ones $80 \mathrm{a}$ and $80 \mathrm{~b}$. 
Table 15. \% Yields of compounds $80 \mathrm{a}$ and $80 \mathrm{~b}$

\begin{tabular}{cccc}
\hline Products & Ar & X & Yeild\% \\
\hline a & 1,3- Benzodioxol-5-yl & O & 52 \\
b & 3-Pyridinyl & S & 58 \\
\hline
\end{tabular}

The reaction of 6 -aminouracil derivatives $\mathbf{3}$ or $\mathbf{6}$ with different aldehydes $\mathbf{2 1}$ and malononitrile (81) under different reaction conditions was reported to give a series of pyrido[2,3-d]pyrimidines $\mathbf{8 2}$ as shown in (Scheme 35). Abdelgawad et al. ${ }^{109}$ reported that pyrido[2,3-d]pyrimidine derivatives (prepared by method A) revealed anti-inflammatory activity by inhibiting cyclooxygenase-2 (COX-2) enzymes (Scheme 35, Table 16).

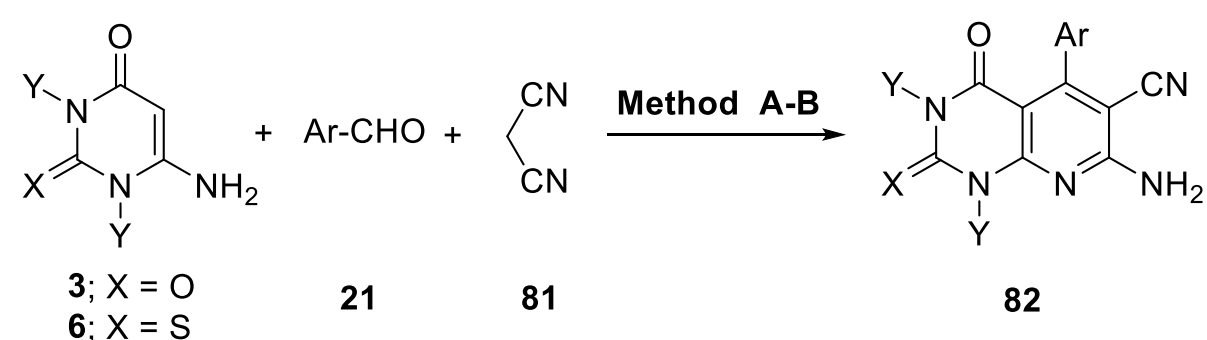
Method A: $\mathrm{EtOH} / \mathrm{Et}_{3} \mathrm{~N}$, reflux, $4 \mathrm{~h}$
Method B: Nano $\mathrm{MgO} / \mathrm{H}_{2} \mathrm{O} / 80^{\circ} \mathrm{C}$
Method C: $\mathrm{Fe}_{3} \mathrm{O}_{4} @ \mathrm{TiO}_{2} @ \mathrm{NH}_{2} @ \mathrm{PMo}_{12} \mathrm{O}_{40} / \mathrm{MNPs} \mathrm{H}_{2} \mathrm{O} / 80^{\circ} \mathrm{C}$
Method D: Electrolysis $50 \mathrm{~mA}, \mathrm{ROH}$ or $\mathrm{MeCN}, \mathrm{NaBr}=\mathrm{Et}, \mathrm{Me}, n-\mathrm{Pr}$

Scheme 35. Synthesis of pyrido[2,3-d]pyrimidines 82.

Table 16. \% Yields of compounds 82

\begin{tabular}{|c|c|c|c|c|c|}
\hline Method & $\mathrm{Ar}$ & $x$ & $\mathrm{Y}$ & Yield\% & Ref. \\
\hline A & $\begin{array}{l}\left(3-\mathrm{H}_{3} \mathrm{CO}-\mathrm{C}_{6} \mathrm{H}_{4}, 2,3-\mathrm{H}_{3} \mathrm{CO}-\mathrm{C}_{6} \mathrm{H}_{4}, 3,4,5-\mathrm{H}_{3} \mathrm{CO}-\right. \\
\left.\mathrm{C}_{6} \mathrm{H}_{4}\right)\end{array}$ & $\mathrm{S}$ & $\mathrm{H}$ & $79-87$ & 109 \\
\hline & $\begin{array}{l}\left(\mathrm{C}_{6} \mathrm{H}_{5}, 2-\mathrm{Cl}-\mathrm{C}_{6} \mathrm{H}_{4}, 4-\mathrm{Cl}-\mathrm{C}_{6} \mathrm{H}_{4}, 4-\mathrm{H}_{3} \mathrm{CO}-\mathrm{C}_{6} \mathrm{H}_{4}, 4-\right. \\
\mathrm{H}_{3} \mathrm{C}-\mathrm{C}_{6} \mathrm{H}_{4}, 3-\mathrm{O}_{2} \mathrm{~N}-\mathrm{C}_{6} \mathrm{H}_{4}, 4-\mathrm{O}_{2} \mathrm{~N}-\mathrm{C}_{6} \mathrm{H}_{4}, 4-\mathrm{Cl}-\end{array}$ & $\mathrm{O}, \mathrm{S}$ & $\mathrm{H}, \mathrm{Me}$ & $84-96$ & 110 \\
\hline B & $\begin{array}{l}\mathrm{C}_{6} \mathrm{H}_{4} ; 3-\mathrm{Cl}-\mathrm{C}_{6} \mathrm{H}_{4}, 2-\mathrm{Cl}-\mathrm{C}_{6} \mathrm{H}_{4}, 3-\mathrm{Br}-\mathrm{C}_{6} \mathrm{H}_{4}, 4-\mathrm{F}- \\
\left.\mathrm{C}_{6} \mathrm{H}_{4}, \mathrm{C}_{6} \mathrm{H}_{5}, 4-\mathrm{Cl}-\mathrm{C}_{6} \mathrm{H}_{4}, 4-\mathrm{Br}-\mathrm{C}_{6} \mathrm{H}_{4}, 4-\mathrm{F}-\mathrm{C}_{6} \mathrm{H}_{4}\right)\end{array}$ & & & & \\
\hline & $\left(4-\mathrm{Cl}-\mathrm{C}_{6} \mathrm{H}_{4}, 3-\mathrm{O}_{2} \mathrm{~N}-\mathrm{C}_{6} \mathrm{H}_{4}, 4-\left(\mathrm{H}_{3} \mathrm{C}\right)_{2} \mathrm{~N}-\mathrm{C}_{6} \mathrm{H}_{3}, 3-\right.$ & & & & \\
\hline & $\mathrm{Cl}-\mathrm{C}_{6} \mathrm{H}_{4}, 4-\mathrm{F}-\mathrm{C}_{6} \mathrm{H}_{4}, 2,4-\mathrm{Cl}_{2}-\mathrm{C}_{6} \mathrm{H}_{4}, 4-\mathrm{Br}-\mathrm{C}_{6} \mathrm{H}_{4}, 2-$ & & & & \\
\hline $\mathbf{C}$ & $\begin{array}{l}\mathrm{Cl}-\mathrm{C}_{6} \mathrm{H}_{4}, 2,6-\mathrm{Cl}_{2}-\mathrm{C}_{6} \mathrm{H}_{3}, 4-\mathrm{O}_{2} \mathrm{~N}-\mathrm{C}_{6} \mathrm{H}_{4}, 3-\mathrm{H}_{3} \mathrm{CO}- \\
\left.\mathrm{C}_{6} \mathrm{H}_{4}, 2-\mathrm{O}_{2} \mathrm{~N}-\mathrm{C}_{6} \mathrm{H}_{4}\right)\end{array}$ & $\mathrm{S}$ & $\mathrm{H}$ & $92-98$ & 111 \\
\hline & $\left(\mathrm{C}_{6} \mathrm{H}_{5}, 4-\mathrm{H}_{3} \mathrm{CO}-\mathrm{C}_{6} \mathrm{H}_{4}, 4-\mathrm{O}_{2} \mathrm{~N}-\mathrm{C}_{6} \mathrm{H}_{4}, 3-\mathrm{O}_{2} \mathrm{~N}-\right.$ & & & & \\
\hline D & $\begin{array}{l}\mathrm{C}_{6} \mathrm{H}_{4}, 2,4-\mathrm{Cl}_{2}-\mathrm{C}_{6} \mathrm{H}_{3}, 3-\mathrm{HO}-\mathrm{C}_{6} \mathrm{H}_{4}, 4-\mathrm{Cl}-\mathrm{C}_{6} \mathrm{H}_{4}, 4- \\
\left.\mathrm{O}_{2} \mathrm{~N}-\mathrm{C}_{6} \mathrm{H}_{4}\right)\end{array}$ & $\mathrm{O}$ & $\mathrm{H}, \mathrm{Me}$ & $90-93$ & 112 \\
\hline
\end{tabular}

A series of tetrahydropyrido[2,3-d]pyrimidines $\mathbf{8 4}$ were prepared in excellent yields via a three component reaction of compound $\mathbf{8 3}$ with the appropriate aryl aldehydes $\mathbf{2 1}$ and malononitrile $\mathbf{8 1}$ using magnetic 
nanoparticles $\mathrm{Fe}_{3} \mathrm{O}_{4} @ \mathrm{TiO}_{2} @ \mathrm{NH}_{2} @ \mathrm{PMo}_{12} \mathrm{O}_{40}$ as a recoverable catalyst. Compounds 83 were synthesized upon alkylation of 6-aminothiouracil (6) with the appropriate alkyl halides under basic condition (Scheme 36, Table 17). ${ }^{111}$

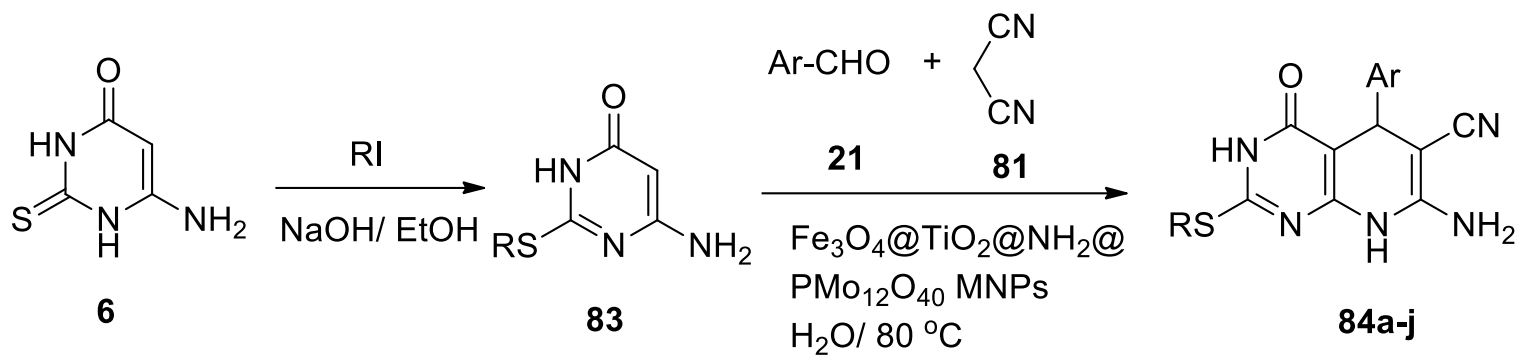

Scheme 36. Synthesis of tetrahydropyrido[2,3-d]pyrimidines $\mathbf{8 4 a - j .}$

Table 17. \% Yields of compounds 84a-j

\begin{tabular}{llll}
\hline $\mathrm{Ar}$ & \multicolumn{1}{c}{$\mathrm{R}$} & Yeild\% & Ref. \\
\hline$\left(3-\mathrm{O}_{2} \mathrm{~N}-\mathrm{C}_{6} \mathrm{H}_{4}, 2,6-\mathrm{Cl}_{2}-\mathrm{C}_{6} \mathrm{H}_{4}, 4-\mathrm{Cl}-\mathrm{C}_{6} \mathrm{H}_{4}\right.$, & $\mathrm{C}_{2} \mathrm{H}_{5}, \mathrm{C}_{3} \mathrm{H}_{7}$, & & \\
$2,4-\mathrm{Cl}_{2}-\mathrm{C}_{6} \mathrm{H}_{4}, 3-\mathrm{O}_{2} \mathrm{~N}-\mathrm{C}_{6} \mathrm{H}_{4}, 4-\mathrm{Cl}_{-} \mathrm{C}_{6} \mathrm{H}_{4}, 3-$ & $\mathrm{C}_{4} \mathrm{H}_{9}$ & $94-98$ & 111 \\
$\mathrm{O}_{2} \mathrm{~N}-\mathrm{C}_{6} \mathrm{H}_{4}, 4-\mathrm{F}-\mathrm{C}_{6} \mathrm{H}_{4} ; 2,4-\mathrm{Cl}_{2}-\mathrm{C}_{6} \mathrm{H}_{4}, 3-$ & & & \\
$\left.\mathrm{O}_{2} \mathrm{~N}-\mathrm{C}_{6} \mathrm{H}_{4}\right)$ & & & \\
\hline
\end{tabular}

A bis(pyrido[2,3-d]pyrimidine-6-carbonitrile) 86 was prepared through a one pot reaction of terephthalaldehyde (85) with two equivalents of both of 6-aminothiouracil (6) and malononitrile (81) (Scheme 37). ${ }^{111}$

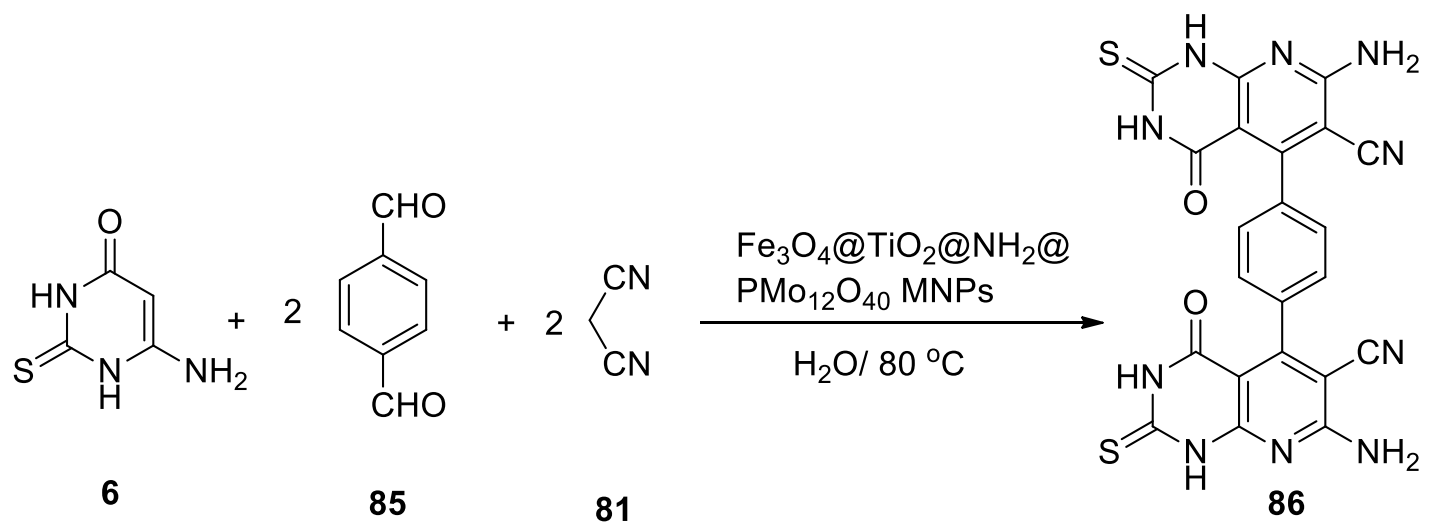

Scheme 37. Synthesis of bis pyrido[2,3-d]pyrimidine-6-carbonitrile 86.

Dihydropyrido[2,3- $d$ ]pyrimidine derivatives 88a-s were prepared via a three component reaction of aminothiouracil derivatives $\mathbf{3}$ or $\mathbf{6}$ with each of aromatic aldehydes $\mathbf{2 1}$ and 2-(phenylsulfonyl) acetonitrile (87) in ethanol at reflux and in the presence of trimethylamine as a catalyst (Scheme 38, Table 18). ${ }^{113}$ 


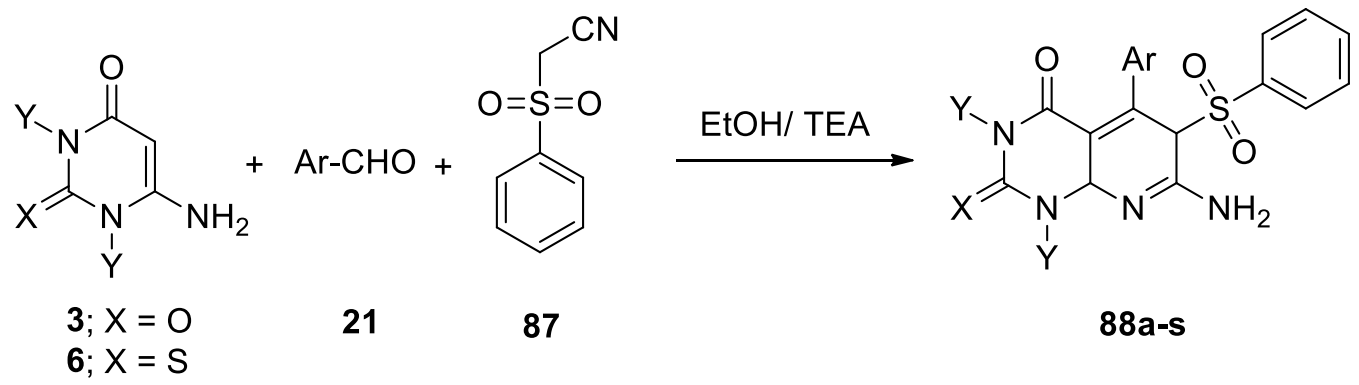

Scheme 38. Synthesis of dihydropyrido[2,3-d]pyrimidine derivatives 88a-s.

Table 18. \% Yields of compounds 88a-s

\begin{tabular}{|c|c|c|c|c|}
\hline Products & $\mathrm{Ar}$ & $Y$ & $x$ & Yield\% \\
\hline a & $4-\mathrm{H}_{3} \mathrm{C}-\mathrm{C}_{6} \mathrm{H}_{5}$ & $\mathrm{Me}$ & $\mathrm{O}$ & 67 \\
\hline b & $3-\mathrm{H}_{3} \mathrm{C}-\mathrm{C}_{6} \mathrm{H}_{4}$ & $\mathrm{Me}$ & 0 & 63 \\
\hline c & $\mathrm{C}_{6} \mathrm{H}_{5}$ & $\mathrm{Me}$ & $\mathrm{O}$ & 79 \\
\hline d & $4-\mathrm{Br}-\mathrm{C}_{6} \mathrm{H}_{4}$ & $\mathrm{Me}$ & 0 & 85 \\
\hline e & $3-\mathrm{Br}-\mathrm{C}_{6} \mathrm{H}_{4}$ & $\mathrm{Me}$ & 0 & 89 \\
\hline$f$ & $4-\mathrm{Cl}-\mathrm{C}_{6} \mathrm{H}_{4}$ & $\mathrm{Me}$ & 0 & 77 \\
\hline g & $2-\mathrm{Cl}-\mathrm{C}_{6} \mathrm{H}_{4}$ & $\mathrm{Me}$ & $\mathrm{O}$ & 81 \\
\hline h & $4-\mathrm{F}-\mathrm{C}_{6} \mathrm{H}_{4}$ & $\mathrm{Me}$ & $\mathrm{O}$ & 74 \\
\hline $\mathbf{i}$ & $4-\mathrm{O}_{2} \mathrm{~N}-\mathrm{C}_{6} \mathrm{H}_{4}$ & $\mathrm{Me}$ & $\mathrm{O}$ & 69 \\
\hline $\mathbf{j}$ & $3-\mathrm{O}_{2} \mathrm{~N}-\mathrm{C}_{6} \mathrm{H}_{4}$ & $\mathrm{Me}$ & 0 & 72 \\
\hline k & $4-\mathrm{H}_{3} \mathrm{C}-\mathrm{C}_{6} \mathrm{H}_{4}$ & $\mathrm{H}$ & $\mathrm{S}$ & 68 \\
\hline I & $3-\mathrm{H}_{3} \mathrm{C}-\mathrm{C}_{6} \mathrm{H}_{4}$ & $\mathrm{H}$ & $S$ & 60 \\
\hline m & $4-\mathrm{H}_{3} \mathrm{CO}-\mathrm{C}_{6} \mathrm{H}_{4}$ & $\mathrm{H}$ & $\mathrm{S}$ & 62 \\
\hline $\mathbf{n}$ & $\mathrm{C}_{6} \mathrm{H}_{5}$ & $\mathrm{H}$ & $\mathrm{S}$ & 87 \\
\hline 0 & $4-\mathrm{Br}-\mathrm{C}_{6} \mathrm{H}_{4}$ & $\mathrm{H}$ & $S$ & 91 \\
\hline $\mathbf{p}$ & $3-\mathrm{Br}-\mathrm{C}_{6} \mathrm{H}_{4}$ & $\mathrm{H}$ & $\mathrm{S}$ & 92 \\
\hline $\mathbf{q}$ & $4-\mathrm{Cl}-\mathrm{C}_{6} \mathrm{H}_{4}$ & $\mathrm{H}$ & $S$ & 81 \\
\hline$r$ & $2-\mathrm{Cl}-\mathrm{C}_{6} \mathrm{H}_{4}$ & $\mathrm{H}$ & $S$ & 91 \\
\hline $\mathbf{s}$ & $4-\mathrm{O}_{2} \mathrm{~N}-\mathrm{C}_{6} \mathrm{H}_{4}$ & $\mathrm{H}$ & $\mathrm{S}$ & 75 \\
\hline
\end{tabular}

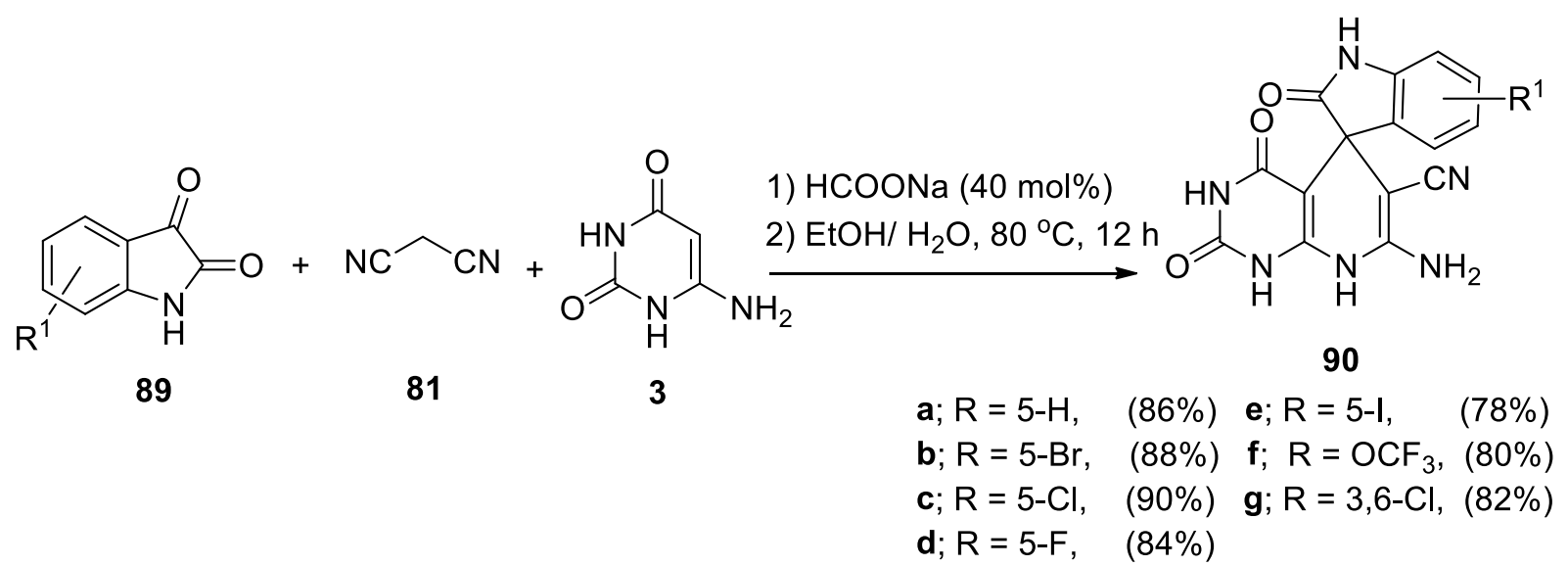

Scheme 39. Synthesis of spiro[indoline-3,5`-pyrido[2,3-d]pyrimidine] derivatives 90 a-g. 
A series of some spiro[indoline-3,5'-pyrido[2,3-d]pyrimidine] derivatives 90a-g were synthesized via a multicomponent reaction of isatins $\mathbf{8 9}$, aminouracil (3), and malononitrile (81) in aqueous ethanol at reflux using sodium format as an organocatalyst (scheme 39). ${ }^{114}$

3.2.1.3.2. Synthesis of pyrimido[1,6-a]pyrimidine. Cyclocondensation of aminouracil derivatives 3 or 6 with 4oxo-4H-chromene-3-carbaldehyde 91 in the presence of anhydrous sodium acetate afforded pyrimido[1,6a]pyrimidinones $\mathbf{9 2 a}$ and $\mathbf{9 2} \mathbf{b}$ in $83 \%$ and $\mathbf{7 4 \%}$ yields, respectively (Scheme 40 ). ${ }^{115}$<smiles>O=Cc1coc2ccccc2c1=O</smiles>

91<smiles></smiles>

$3 ; X=0$ $6 ; X=S$

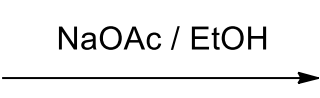<smiles></smiles>

92a; $X=S ;(83 \%)$

b; $X=0 ;(74 \%)$

Scheme 40 . Synthesis of pyrimido[1,6-a]pyrimidinones $\mathbf{9 2 a}$ and $\mathbf{9 2} \mathbf{b}$.

Pyrimido[1,6-a]pyrimidine-3-carbonitrile 94 was prepared by the reaction of 6-aminothiouracil (6) with 2cyano-3-(1,3-diphenyl-1H-pyrazol-4-yl)acryloyl chloride (93) at reflux in dioxane in the presence of TEA (scheme 41). ${ }^{116}$<smiles>[NH3+]c1cc(=O)[nH]c(=S)[nH]1</smiles>

6<smiles>N#C/C(=C\c1cn(-c2ccccc2)nc1-c1ccccc1)C(=O)Cl</smiles>
93

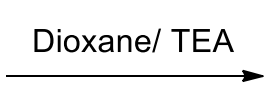<smiles>N#CC1C(=O)Nc2cc(=O)[nH]c(=S)n2C1c1cn(-c2ccccc2)nc1-c1ccccc1</smiles>

94

Scheme 41. Synthesis of pyrimido[1,6-a]pyrimidine-3-carbonitrile 94.

3.2.1.4. Fused [6-6]systems: Four heteroatoms. 3.2.1.4.1. Synthesis of pyrimido[4,5-d]pyrimidine. Khodabakhshi et al. ${ }^{117}$ reported the synthesis of tetrahydropyrimido[4,5-d]pyrimidine-2,4-dione derivatives 96a-e through cyclization of 6-aminothiouracil (6) with $N, N^{\prime}$-bis(arylmethylidene) arylmethanes(diimines) 95 using $p$-TSA as a catalyst. The ${ }^{1} \mathrm{H}-\mathrm{NMR}$ spectroscopy indicated the presence of the anti-configured diastereomer in all products. (Scheme 42, Table 19).<smiles>Nc1cc(=O)[nH]c(=S)[nH]1</smiles>

6<smiles>Br/C=N/C(Br)/N=C/[Bi]</smiles>

95

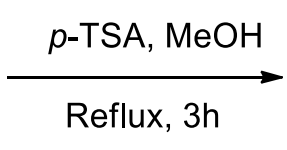<smiles>O=C1NC(=S)NC2NC(Br)NC(Br)C12</smiles>

96a-e

Scheme 42. Synthesis of tetrahydropyrimido[4,5-d]pyrimidine-2,4-diones 96a-e. 
Table 19. \% Yields of compounds 96a-e

\begin{tabular}{ccc}
\hline Products & $\mathrm{Ar}$ & Yield\% \\
\hline a & $\mathrm{C}_{6} \mathrm{H}_{5}$ & 80 \\
b & $4-\mathrm{H}_{3} \mathrm{C}-\mathrm{C}_{6} \mathrm{H}_{4}$ & 75 \\
c & $4-\mathrm{H}_{3} \mathrm{CO}-\mathrm{C}_{6} \mathrm{H}_{4}$ & 78 \\
d & 2- $\mathrm{H}_{3} \mathrm{C}-\mathrm{C}_{6} \mathrm{H}_{4}$ & 72 \\
e & 2-Thienyl & 93 \\
\hline
\end{tabular}

6-(4-Acetylphenyl)-2-thioxo-hexahydro-1H-pyrimido[4,5-d]pyrimidin-4-one (99) was synthesized in $92 \%$ yield through the reaction of 6-aminothiouracil (6) with each of 4-aminoacetophenone (98) and formaldehyde (97) in a mixture of acetic acid and isopropyl alcohol (Scheme 43). ${ }^{109}$

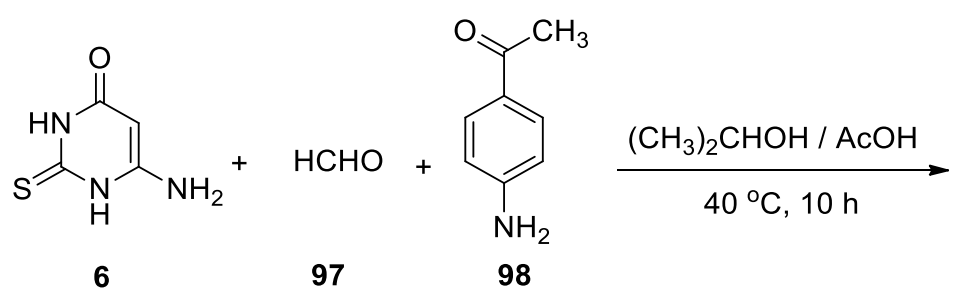

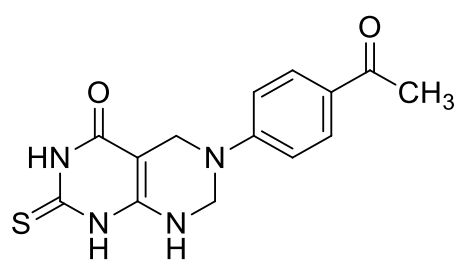

99; $(90 \%)$

Scheme 43. Synthesis of 6-(4-acetylphenyl)-2-thioxo-hexahydro-1H-pyrimido[4,5-d]pyrimidin-4-one 99.

3.2.2. Synthesis of fused tricyclic systems. 3.2.2.1. Fused [5-6-6]systems: Three heteroatoms. 3.2.2.1.1. Synthesis of cyclopenta[5,6]pyrido[2,3-d]pyrimidine. Hexahydro-4H-cyclopenta[5,6]pyrido[2,3- $d$ ]pyrimidin-4one 101 was prepared through a cyclocondensation reaction of one equivalent of each of cyclopentanone (100) and aminothiouracil (6) with two equivalent of $p$-anisaldehyde (21) in DMF. The reaction was carried out under conventional heating or microwave irradiation (Scheme 44). Compound 101 showed a good corrosion inhibitory effect for API 5L X52 carbon steel in 5\% sulfamic acid solutions (Scheme 44). ${ }^{118}$

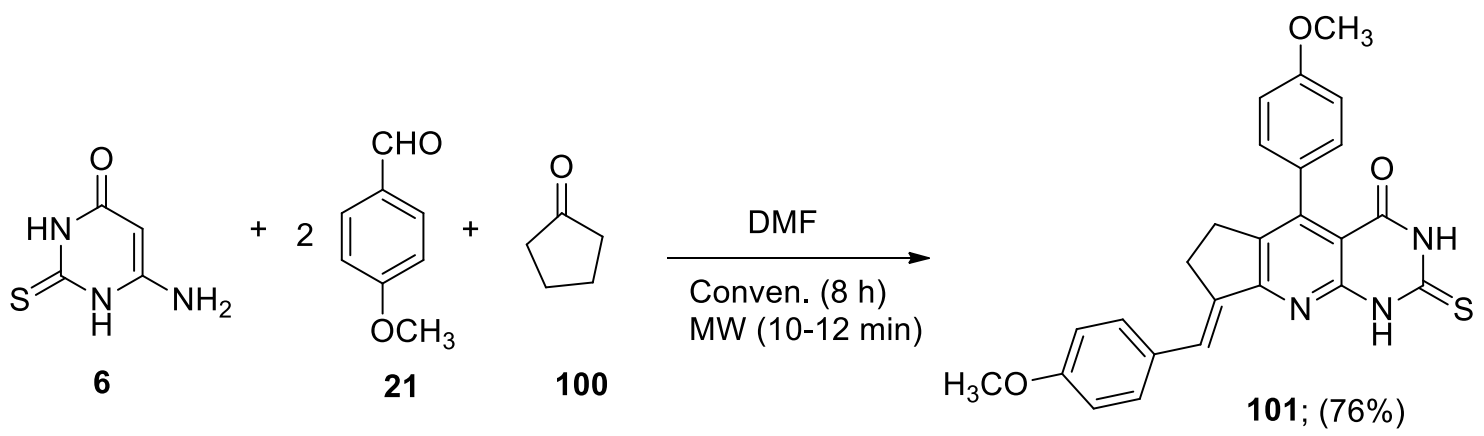

Scheme 44. Synthesis of hexahydro-4H-cyclopenta[5,6]pyrido[2,3-d]pyrimidin-4-one 101.

3.2.2.2. Fused [5-6-6]systems: five heteroatoms. 3.2.2.2.1 Synthesis of pyrazolo[ $\left.4^{\prime}, 3^{\prime}: 5,6\right]$ pyrido[2,3d]pyrimidin-5-one. The synthesis of a variety of pyrazolo[4', $\left.3^{\prime}: 5,6\right]$ pyrido[2,3- $\left.d\right]$ pyrimidin-5-one derivatives 102a-r was established in good yields via a one pot reaction of 6-aminothiouracil (6) with aldehydes 21 and 3methyl-1-aryl-2-pyrazoline-5-one $\mathbf{3 3}$ in ethanol at reflux in the presence of piperidine as a basic catalyst (Scheme 45, Table 20). ${ }^{119}$ 


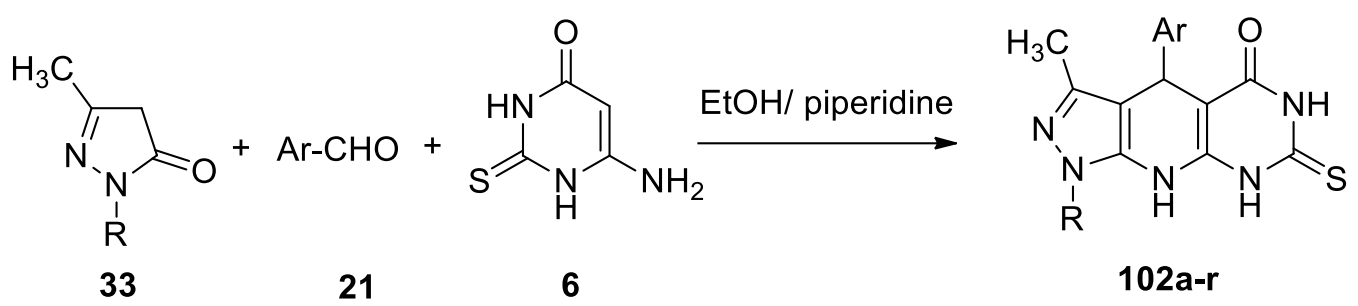

Scheme 45. Synthesis of pyrazolo[ $\left[4^{\prime}, 3^{\prime}: 5,6\right]$ pyrido[2,3-d]pyrimidin-5-one derivatives 102a-r.

Table 20. \% Yields of compounds 102a-r

\begin{tabular}{|c|c|c|c|}
\hline Products & $\mathrm{R}$ & $\mathrm{Ar}$ & Yeild\% \\
\hline a & $\mathrm{C}_{6} \mathrm{H}_{5}$ & $4-\mathrm{Cl}-\mathrm{C}_{6} \mathrm{H}_{4}$ & 96 \\
\hline b & $\mathrm{C}_{6} \mathrm{H}_{5}$ & $4-\mathrm{F}_{3} \mathrm{C}-\mathrm{C}_{6} \mathrm{H}_{4}$ & 69 \\
\hline c & $\mathrm{C}_{6} \mathrm{H}_{5}$ & $4-\mathrm{H}_{3} \mathrm{CO}-\mathrm{C}_{6} \mathrm{H}_{4}$ & 74 \\
\hline d & $\mathrm{C}_{6} \mathrm{H}_{5}$ & $4-\mathrm{Br}-\mathrm{C}_{6} \mathrm{H}_{4}$ & 95 \\
\hline e & $\mathrm{C}_{6} \mathrm{H}_{5}$ & $4-\mathrm{F}-\mathrm{C}_{6} \mathrm{H}_{4}$ & 72 \\
\hline$f$ & $\mathrm{C}_{6} \mathrm{H}_{5}$ & $4-\mathrm{O}_{2} \mathrm{~N}-\mathrm{C}_{6} \mathrm{H}_{4}$ & 94 \\
\hline g & $\mathrm{C}_{6} \mathrm{H}_{5}$ & $2-\mathrm{Cl}-\mathrm{C}_{6} \mathrm{H}_{4}$ & 70 \\
\hline h & $\mathrm{C}_{6} \mathrm{H}_{5}$ & $3-\mathrm{Cl}-\mathrm{C}_{6} \mathrm{H}_{4}$ & 89 \\
\hline $\mathbf{i}$ & $\mathrm{C}_{6} \mathrm{H}_{5}$ & $3-\mathrm{F}-\mathrm{C}_{6} \mathrm{H}_{4}$ & 98 \\
\hline $\mathbf{j}$ & $3-\mathrm{Cl}-\mathrm{C}_{6} \mathrm{H}_{4}$ & $4-\mathrm{Cl}-\mathrm{C}_{6} \mathrm{H}_{4}$ & 98 \\
\hline k & $3-\mathrm{Cl}-\mathrm{C}_{6} \mathrm{H}_{4}$ & $4-\mathrm{Br}-\mathrm{C}_{6} \mathrm{H}_{4}$ & 92 \\
\hline I & $3-\mathrm{Cl}-\mathrm{C}_{6} \mathrm{H}_{4}$ & $4-\mathrm{F}-\mathrm{C}_{6} \mathrm{H}_{4}$ & 69 \\
\hline m & $3-\mathrm{Cl}-\mathrm{C}_{6} \mathrm{H}_{4}$ & $4-\mathrm{F}_{3} \mathrm{C}-\mathrm{C}_{6} \mathrm{H}_{4}$ & 75 \\
\hline $\mathbf{n}$ & $3-\mathrm{Cl}-\mathrm{C}_{6} \mathrm{H}_{4}$ & $3-\mathrm{F}-\mathrm{C}_{6} \mathrm{H}_{4}$ & 98 \\
\hline 0 & $3-\mathrm{Cl}-\mathrm{C}_{6} \mathrm{H}_{4}$ & $4-\mathrm{O}_{2} \mathrm{~N}-\mathrm{C}_{6} \mathrm{H}_{4}$ & 95 \\
\hline p & $3-\mathrm{Cl}-\mathrm{C}_{6} \mathrm{H}_{4}$ & $4-\mathrm{Cl}-\mathrm{C}_{6} \mathrm{H}_{4}$ & 78 \\
\hline q & $3-\mathrm{Cl}-\mathrm{C}_{6} \mathrm{H}_{4}$ & $4-\mathrm{F}-\mathrm{C}_{6} \mathrm{H}_{4}$ & 91 \\
\hline$r$ & $3-\mathrm{Cl}-\mathrm{C}_{6} \mathrm{H}_{4}$ & $4-\mathrm{O}_{2} \mathrm{~N}-\mathrm{C}_{6} \mathrm{H}_{4}$ & 85 \\
\hline
\end{tabular}

3.2.2.2. Synthesis of isoxazolo $\left[4^{\prime}, 5^{\prime}: 5,6\right]$ pyrido $[2,3-d]$ pyrimidine. Poomathi et al. ${ }^{120}$ reported the synthesis of spiroindoline-3,4'isoxazolo[4',5':5,6]pyrido[2,3-d]pyrimidine derivatives 104a-h in good yields via a one pot reaction of isatin 89 with each of 6 -aminouracil 3 and 3-phenylisoxazol-5(4H)-one (103) in the presence of $p$ toluenesulfonic acid as a catalyst in water as a green solvent (Scheme 46, Table 21).

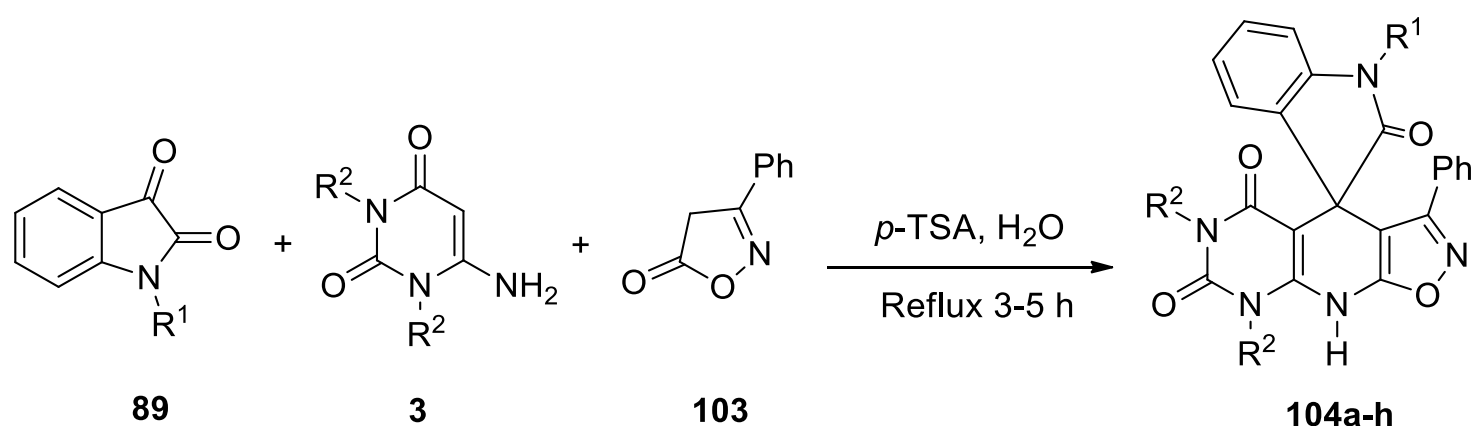

Scheme 46. Synthesis of spiroindoline-3,4'isoxazolo[4',5':5,6]pyrido[2,3-d]pyrimidines 104a-h. 
Table 21. \% Yields of compounds 104a-h

\begin{tabular}{cccc}
\hline Products & $\mathrm{R}^{1}$ & $\mathrm{R}^{2}$ & Yield\% \\
\hline a & $\mathrm{CH}_{3}$ & $\mathrm{CH}_{3}$ & 87 \\
b & $\mathrm{CH}_{2} \mathrm{CH}_{3}$ & $\mathrm{CH}_{3}$ & 89 \\
c & $\mathrm{CH}_{2} \mathrm{CH}=\mathrm{CH}_{2}$ & $\mathrm{CH}_{3}$ & 86 \\
d & $\mathrm{CH}_{2}-\mathrm{C}_{6} \mathrm{H}_{5}$ & $\mathrm{CH}_{3}$ & 79 \\
e & $\mathrm{CH}_{3}$ & $\mathrm{H}$ & 88 \\
$\mathbf{f}$ & $\mathrm{CH}_{2} \mathrm{CH}_{3}$ & $\mathrm{H}$ & 87 \\
g & $\mathrm{CH}_{2} \mathrm{CH}=\mathrm{CH}_{2}$ & $\mathrm{H}$ & 87 \\
h & $\mathrm{CH}_{2}-\mathrm{C}_{6} \mathrm{H}_{5}$ & $\mathrm{H}$ & 81 \\
\hline
\end{tabular}

3.2.2. Fused [6-6-6]systems: three heteroatoms. 3.2.2.3.1. Synthesis of pyrimido[4,5-b]quinolone. Malki et al. ${ }^{121}$ reported the synthesis of 2-(methylthio)pyrimido[4,5- $b$ ]quinolin-4(3H)-one derivatives $106 a-d$ by firstly, the reaction of 6-aminothiouracil (6) with the appropriate aniline 47 to give the corresponding 6-anilino derivatives $\mathbf{1 0 5 a - d . ~ T h e ~ l a t t e r ~ c o m p o u n d s ~ w e r e ~ t h e n ~ c y c l i z e d ~ t h r o u g h ~ V i l s m e i e r - H a a c k ~ r e a c t i o n ~ t o ~ g i v e ~}$ compounds 106a-d in good yields (Scheme 47).
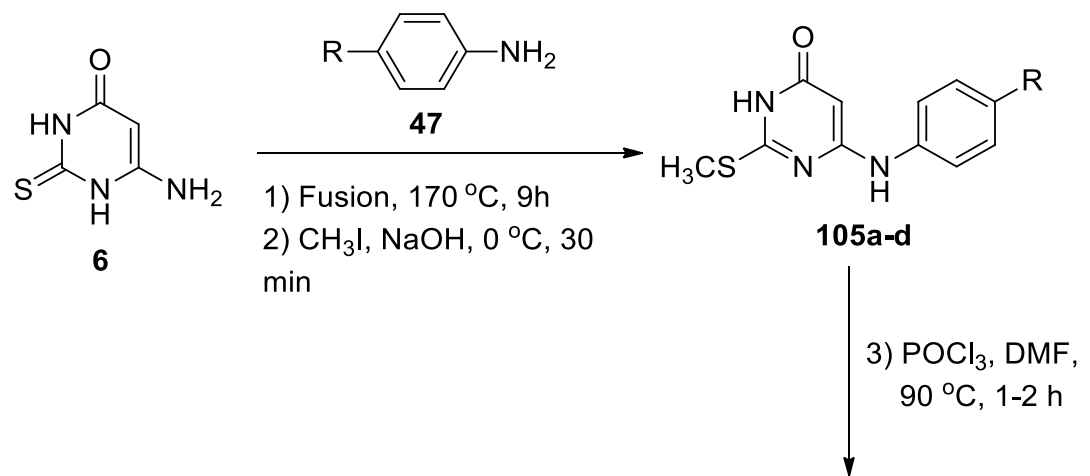<smiles>[R]c1ccc2nc3nc(SC)[nH]c(=O)c3cc2c1</smiles>

$$
\begin{aligned}
\text { 106a; } R & =H, \quad(62 \%) \\
\text { b; } R & =\mathrm{CH}_{3},(77 \%) \\
\text { c; } R & =O \mathrm{OCH}_{3},(87 \%) \\
\text { d; } \mathrm{R} & =\mathrm{Cl},(87 \%)
\end{aligned}
$$

Scheme 47. Synthesis of 2-(methylthio)pyrimido[4,5-b]quinolin-4(3H)-one derivatives 106a-d.

Hovsepyan et al. ${ }^{122}$ reported the synthesis of pyrimido[4,5-b]quinolone derivatives 107a-c in acceptable yields through a three-component cyclization of 6-amino-2-substituted pyrimidines 55a-c with each of aryl aldehydes $\mathbf{2 1}$ and dimedone (42) in $\mathrm{H}_{2} \mathrm{O}$ at reflux and in the presence of triethylbenzylammonium chloride as a catalyst (Scheme 48). 


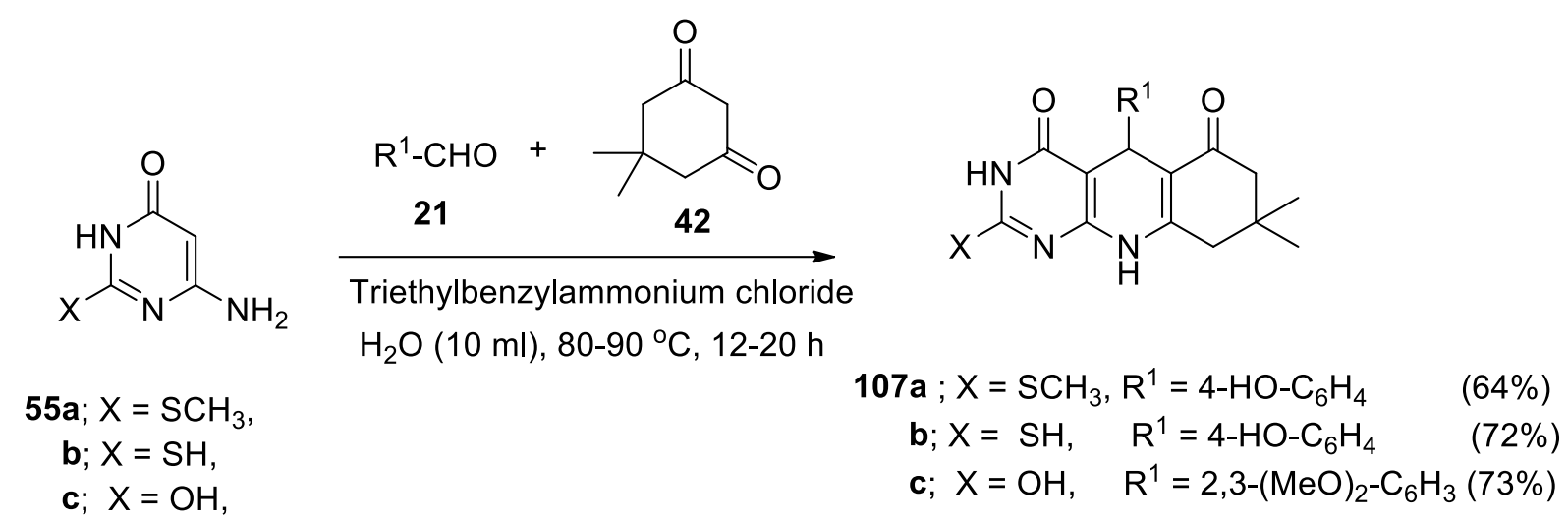

Scheme 48. Synthesis of pyrimido[4,5-b]quinolone derivatives 107a-c.

Pyrimido[4,5-b]quinoline derivatives 108a-e were synthesized via electrochemically induced condensation of aryl aldehydes 21 with 6-amino-1,3-dimethyluracil (3) and dimedone (42) in EtOH and in the presence of $\mathrm{NaBr}$ (Scheme 49, Table 22). ${ }^{112}$<smiles>CN1C(=O)C=C(N)N(C)N(C)C1=O</smiles>

Scheme 49. Synthesis of pyrimido[4,5-b]quinoline derivatives 108a-e.

Table 22. \% Yields of compounds 108a-e

\begin{tabular}{ccc}
\hline Products & $\mathrm{Ar}$ & Yeild\% \\
\hline a & $4-\mathrm{HO}-\mathrm{C}_{6} \mathrm{H}_{4}$ & 88 \\
b & $4-\mathrm{H}_{3} \mathrm{CO}-\mathrm{C}_{6} \mathrm{H}_{4}$ & 92 \\
c & $4-\mathrm{O}_{2} \mathrm{~N}-\mathrm{C}_{6} \mathrm{H}_{4}$ & 92 \\
d & $4-\mathrm{Cl}-\mathrm{C}_{6} \mathrm{H}_{4}$ & 93 \\
e & $4-\mathrm{Br}-\mathrm{C}_{6} \mathrm{H}_{4}$ & 90 \\
\hline
\end{tabular}

A variety of spirocyclic oxindole derivatives 109a-k were synthesized in good yields via a multi-component reaction of isatin 89, aminouracils 3 or $\mathbf{6}$ and dimedone (42) using different catalytic systems. Baharfar et al. ${ }^{123}$ reported that most spirocyclic oxindoles $\mathbf{1 0 9 a - k}$ possessed antioxidant effect by examined its radical scavenging activity (Scheme 50, Table 23). ${ }^{123,124}$ 


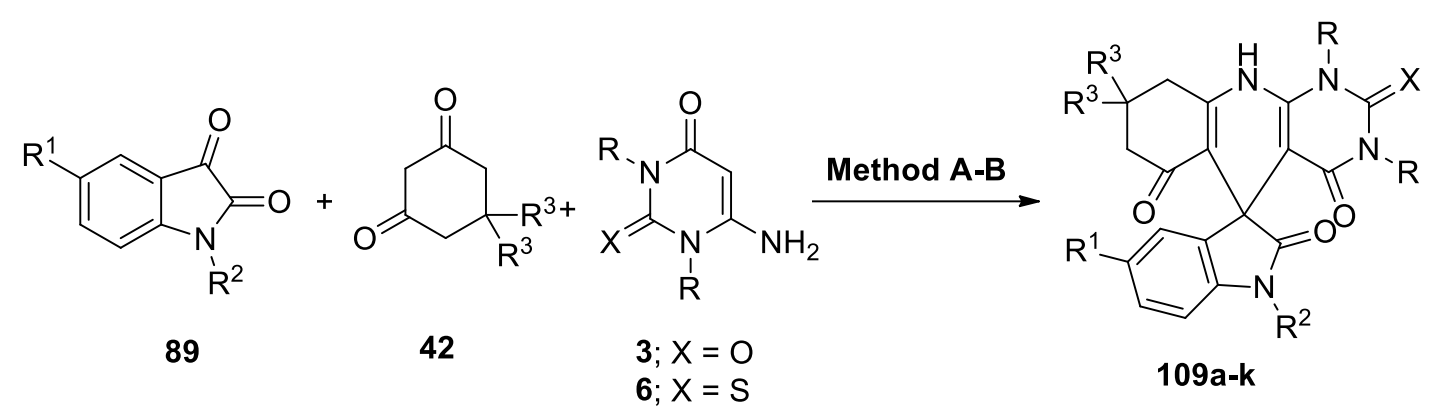

Method A: SBA-15-PhSO ${ }_{3} \mathrm{H}, \mathrm{H}_{2} \mathrm{O}: \mathrm{EtOH}(4: 1), 80^{\circ} \mathrm{C}$

Method B: $\mathrm{H}_{2} \mathrm{O}, 20$ mol\% $p$-TSA, $80^{\circ} \mathrm{C}$

Scheme 50. Synthesis of pyrimido[4,5-b]quinoline derivatives 109a-k.

Table 23. \% Yields of compounds 109a-k

\begin{tabular}{cccccccc}
\hline Products & Method & $\mathrm{R}^{1}$ & $\mathrm{R}^{2}$ & $\mathrm{R}^{3}$ & $\mathrm{R}$ & $\mathrm{X}$ & Yield\% \\
\hline $\mathbf{a}$ & $\mathrm{A}, \mathrm{B}$ & $\mathrm{H}$ & $\mathrm{H}$ & $\mathrm{CH}_{3}$ & $\mathrm{CH}_{3}$ & $\mathrm{O}$ & $94-92$ \\
$\mathbf{b}$ & $\mathrm{A}$ & $\mathrm{H}$ & $\mathrm{H}$ & $\mathrm{H}$ & $\mathrm{CH}_{3}$ & $\mathrm{O}$ & 92 \\
$\mathbf{c}$ & $\mathrm{A}$ & $\mathrm{Cl}$ & $\mathrm{H}$ & $\mathrm{CH}_{3}$ & $\mathrm{CH}_{3}$ & $\mathrm{O}$ & 91 \\
$\mathbf{d}$ & $\mathrm{A}$ & $\mathrm{Cl}$ & $\mathrm{H}$ & $\mathrm{H}$ & $\mathrm{CH}_{3}$ & $\mathrm{O}$ & 90 \\
$\mathbf{e}$ & $\mathrm{A}$ & $\mathrm{Br}$ & $\mathrm{H}$ & $\mathrm{H}$ & $\mathrm{CH}_{3}$ & $\mathrm{O}$ & 93 \\
$\mathbf{f}$ & $\mathrm{A}$ & $\mathrm{NO}_{2}$ & $\mathrm{H}$ & $\mathrm{CH}_{3}$ & $\mathrm{CH}_{3}$ & $\mathrm{O}$ & 90 \\
$\mathbf{g}$ & $\mathrm{A}$ & $\mathrm{H}$ & $\mathrm{Et}$ & $\mathrm{CH}_{3}$ & $\mathrm{CH}_{3}$ & $\mathrm{O}$ & 92 \\
$\mathbf{h}$ & $\mathrm{A}$ & $\mathrm{H}$ & $\mathrm{CH}_{2} \mathrm{COOEt}$ & $\mathrm{CH}_{3}$ & $\mathrm{CH}_{3}$ & $\mathrm{O}$ & 91 \\
$\mathbf{i}$ & $\mathrm{A}$ & $\mathrm{H}$ & $\mathrm{Bn}$ & $\mathrm{CH}_{3}$ & $\mathrm{CH}_{3}$ & $\mathrm{O}$ & 89 \\
$\mathbf{j}$ & $\mathrm{B}$ & $\mathrm{H}$ & $\mathrm{H}$ & $\mathrm{CH}_{3}$ & $\mathrm{H}$ & $\mathrm{O}$ & 88 \\
$\mathbf{k}$ & $\mathrm{A}, \mathrm{B}$ & $\mathrm{H}$ & $\mathrm{H}$ & $\mathrm{CH}_{3}$ & $\mathrm{H}$ & $\mathrm{S}$ & $90-87$ \\
\hline
\end{tabular}

A three component reaction of bis(aldehydes) 29a-h with two equivalents of both of 6-aminouracil (3) and dimedone (42) under acidic catalytic condition afforded a series of bis(pyrimido[4,5-b]quinolones) 110a-h in good yields (Scheme 51). ${ }^{76}$

Mohamed et al. ${ }^{125}$ reported the synthesis of bis(spiro-cyclic 2-oxindole) linked to pyrimido[4,5- $b$ ] quinolonetetraone derivatives $\mathbf{1 1 2 a - f}$ by the reaction of bis-isatin 111, dimedone (42) and 6-aminouracil (3) in acetic acid at reflux. The latter compounds exhibited a potent cytotoxic effect more than the standard drug fluorouracil (5-FU). Among the tested derivatives, compound 112a was found to be the most active and promising one in this series against MCF7, HCT116, and A549 cell lines (Scheme 52). 


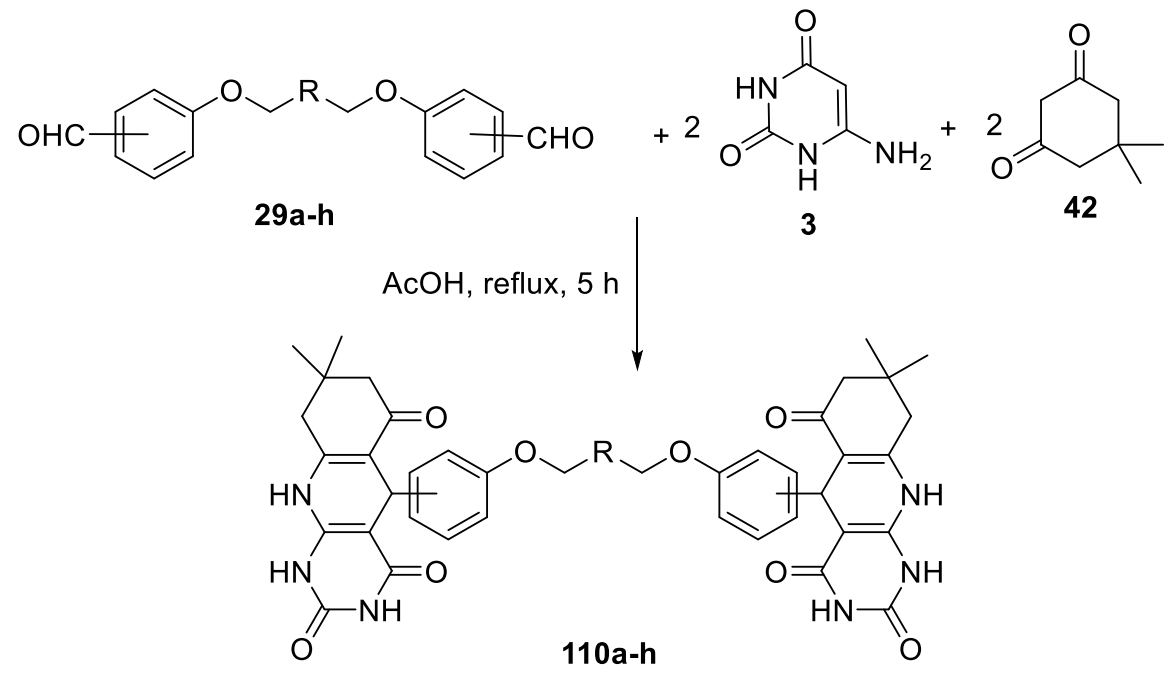
a, $\mathrm{R}=\left(\mathrm{CH}_{2}\right)_{0}$, ortho, $(83 \%)$
f, $R=$
$\{-$ para, (89\%)
b, $\mathrm{R}=\left(\mathrm{CH}_{2}\right)_{0}$, para, $\quad(85 \%)$
c, $\mathrm{R}=\mathrm{CH}_{2}$, ortho, $\quad(86 \%)$
g, $R=$
d, $\mathrm{R}=\left(\mathrm{CH}_{2}\right)_{2}$, ortho, $(88 \%)$

$\mathrm{h}, \mathrm{R}=$

Scheme 51. Synthesis of bis(pyrimido[4,5-b]quinolones) 110a-h.<smiles>[Y]N1C(=O)C(=O)c2ccccc21</smiles>

111<smiles>CC1(C)CC(=O)CC(=O)C1</smiles>

42<smiles>Nc1cc(=O)[nH]c(=O)[nH]1</smiles>

3

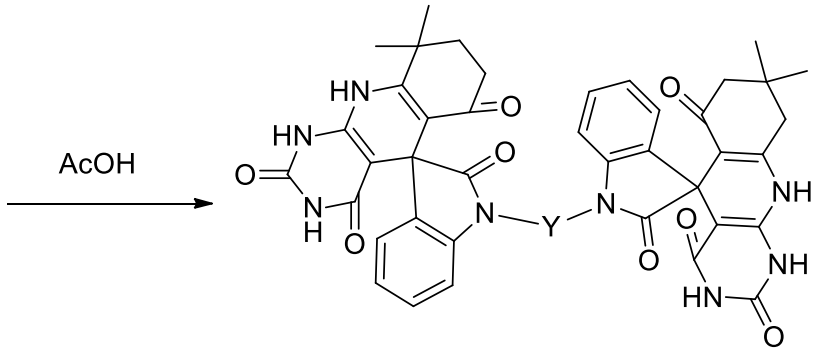

112a-f; (84-90\%)

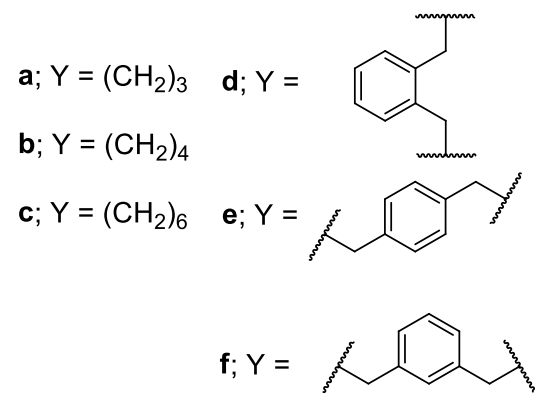

Scheme 52. Synthesis of bis(spiro-cyclic 2-oxindole) linked to pyrimido[4,5-b]quinolonetetraone derivatives 112a-f.

3.2.2.4. Fused [6-6-6]systems: Four heteroatoms. 3.2 .2 .4 .1 . Synthesis of pyrimido $[4,5-h][1,6]$ naphthyridin10(7H)-one. 5-Amino-2,4-dimethyl-8-thioxo-8,9-dihydropyrimido[4,5-h][1,6]naphthyridin-10(7H)-on (114) was 
prepared in 75\% yield by the reaction of 6-aminothiouracil (6) with 2-chloro-4,6-pyridine-3-carbonitrile (113) in ethanol at reflux in the presence of TEA as a catalyst (Scheme 53). ${ }^{106}$

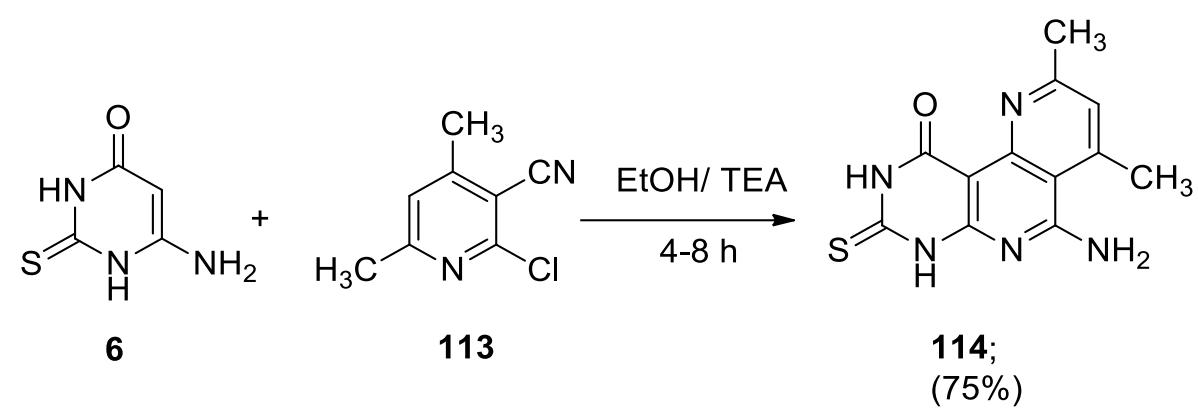

Scheme 53. Synthesis of 5-amino-2,4-dimethyl-8-thioxo-8,9-dihydropyrimido[4,5- $h][1,6]$ naphthyridin-10(7H)one (114).

3.2.2.4.2. Synthesis of pyrimido[4,5-b]-1,8-naphthyridine. Naidu et al. ${ }^{126}$ reported the synthesis of pyrimido[4,5- $b$ ]-1,8-naphthyridine derivatives $116 a-n$ and $117 a-n$ by the reaction of 2-cyano-3-(1H-indol-3-yl)pent-2-enedinitrile or ethyl-2,4-dicyano-3-(1H-indol-3-yl)but-2-enoate derivatives $\mathbf{1 1 5}$ with aryl aldehydes $\mathbf{2 1}$ and 6-aminouracil derivatives 3 in the presence of $\mathrm{Et}_{3} \mathrm{~N}$ in ethanol at reflux (Scheme 54, Table 24).

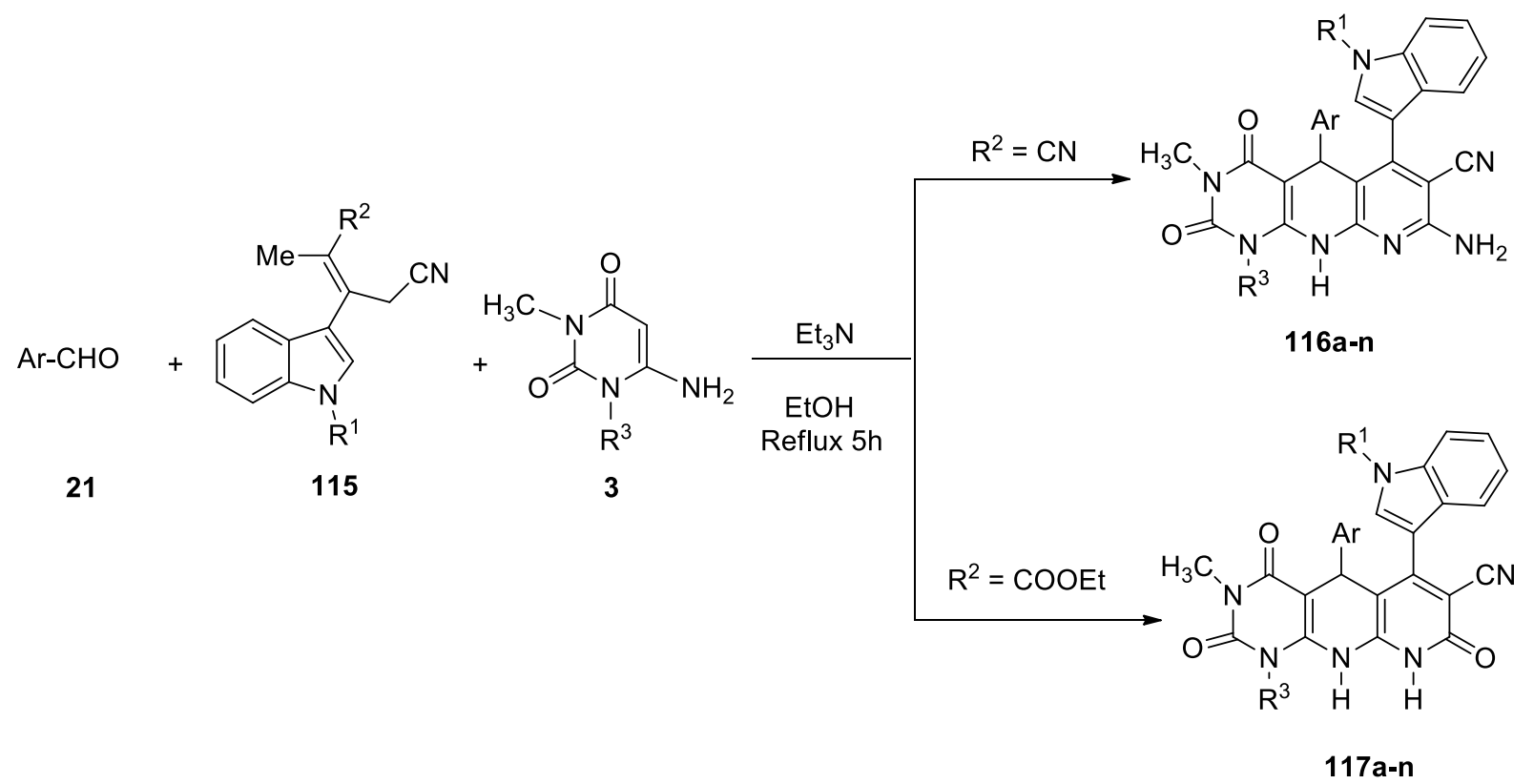

Scheme 54. Synthesis of pyrimido[4,5-b]-1,8-naphthyridine derivatives $116 \mathbf{a}-\mathbf{n}$ and 117a-n. 
Table 24. \% Yields of compounds 116a-n and 117a-n

\begin{tabular}{|c|c|c|c|c|c|}
\hline \multicolumn{2}{|c|}{ Products } & \multirow[t]{2}{*}{$\mathrm{Ar}$} & \multirow[t]{2}{*}{$\mathrm{R}^{1}$} & \multirow[t]{2}{*}{$\mathrm{R}^{3}$} & \multirow[t]{2}{*}{ Yield\% } \\
\hline 116a-I & $117 a-I$ & & & & \\
\hline $\mathbf{a}$ & $\mathbf{a}$ & $-\mathrm{C}_{6} \mathrm{H}_{5}$ & $\mathrm{H}$ & $\mathrm{CH}_{3}$ & $80-79$ \\
\hline b & b & $4-\mathrm{H}_{3} \mathrm{C}-\mathrm{C}_{6} \mathrm{H}_{4}$ & $\mathrm{H}$ & $\mathrm{CH}_{3}$ & $83-84$ \\
\hline C & c & $4-\mathrm{H}_{3} \mathrm{CO}-\mathrm{C}_{6} \mathrm{H}_{4}$ & $\mathrm{H}$ & $\mathrm{CH}_{3}$ & $85-86$ \\
\hline d & d & $4-\mathrm{Cl}-\mathrm{C}_{6} \mathrm{H}_{4}$ & $\mathrm{H}$ & $\mathrm{CH}_{3}$ & $76-74$ \\
\hline e & e & 4-Br- $\mathrm{C}_{6} \mathrm{H}_{4}$ & $\mathrm{H}$ & $\mathrm{CH}_{3}$ & $78-75$ \\
\hline$f$ & $f$ & $4-\mathrm{O}_{2} \mathrm{~N}-\mathrm{C}_{6} \mathrm{H}_{4}$ & $\mathrm{H}$ & $\mathrm{CH}_{3}$ & $66-65$ \\
\hline $\mathbf{g}$ & g & $-\mathrm{C}_{6} \mathrm{H}_{5}$ & $\mathrm{CH}_{3}$ & $\mathrm{CH}_{3}$ & $80-80$ \\
\hline $\mathbf{h}$ & $\mathbf{h}$ & $4-\mathrm{H}_{3} \mathrm{CO}-\mathrm{C}_{6} \mathrm{H}_{4}$ & $\mathrm{CH}_{3}$ & $\mathrm{CH}_{3}$ & $81-83$ \\
\hline $\mathbf{i}$ & $\mathbf{i}$ & $4-\mathrm{Cl}-\mathrm{C}_{6} \mathrm{H}_{4}$ & $\mathrm{CH}_{3}$ & $\mathrm{CH}_{3}$ & $75-77$ \\
\hline $\mathbf{j}$ & j & $4-\mathrm{O}_{2} \mathrm{~N}-\mathrm{C}_{6} \mathrm{H}_{4}$ & $\mathrm{CH}_{3}$ & $\mathrm{CH}_{3}$ & $64-62$ \\
\hline k & k & $-\mathrm{C}_{6} \mathrm{H}_{5}$ & $\mathrm{H}$ & $\mathrm{H}$ & $76-75$ \\
\hline I & I & 2-Pyrrolyl & $\mathrm{H}$ & $\mathrm{CH}_{3}$ & $74-73$ \\
\hline m & m & 2-Thienyl & $\mathrm{H}$ & $\mathrm{CH}_{3}$ & $72-72$ \\
\hline $\mathbf{n}$ & $\mathbf{n}$ & $i-\operatorname{Pr}$ & $\mathrm{H}$ & $\mathrm{CH}_{3}$ & $70-70$ \\
\hline
\end{tabular}

3.2.2.5 Fused [6-6-6]systems: Five heteroatoms. 3.2.2.5.1. Synthesis of pyrimido[ $\left[5^{\prime}, 4^{\prime}: 5,6\right]$ pyrido $[4,3-$ c]pyridazine. Pyrimido[5',4':5,6]pyrido[4,3-c]pyridazines 119a, 119b and 120 were synthesized via reaction of aminothiouracil (6) with chloropyridazines 118a, 118b and 118c in DMF in the presence of piperdine as a catalyst (Scheme 55). ${ }^{106}$

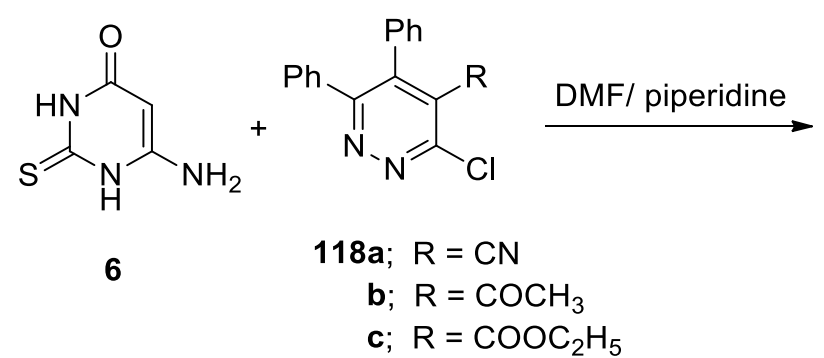<smiles>[R]c1nc2[nH]c(=S)[nH]c(=O)c2c2nnc(-c3ccccc3)c(-c3ccccc3)c12</smiles>

119a; $\mathrm{R}=\mathrm{NH}_{2}(70 \%)$

b; $\mathrm{R}=\mathrm{CH}_{3}(69 \%)$<smiles>O=c1[nH]c(=S)[nH]c(=O)c2c(-c3ccccc3)c(-c3ccccc3)nnc12</smiles>

$120 ; \quad(58 \%)$

Scheme 55. Synthesis of pyrimido[5',4':5,6]pyrido[4,3-c]pyridazines 119a, 119b and 120.

3.2.2.2. Synthesis of pyrido[2,3-d:4,5-d']dipyrimidine. The reaction of 6-aminothiouracil (6) with 4-chloro-2methyl-6-phenyl pyrimidine-5-carbonitrile (121) in DMF in the presence of piperdine as catalyst afforded dihydropyrido[2,3-d:4,5-d']dipyrimidin-10(7H)-one 122 in 78\% yield (Scheme 56). ${ }^{106}$ 
<smiles>Nc1cc(=O)[nH]c(=S)[nH]1</smiles>

6<smiles>Cc1nc(Cl)c(C#N)c(-c2ccccc2)n1</smiles>

121

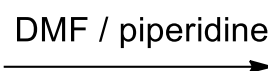<smiles>Cc1nc(-c2ccccc2)c2c(N)nc3[nH]c(=S)[nH]c(=O)c3c2n1</smiles>

122; $(78 \%)$

Scheme 56. Synthesis of dihydropyrido[2,3-d:4,5-d'] dipyrimidin-10(7H)-one 122.

3.2.2.5.3. Synthesis of pyrido[2,3-d:6,5d']dipyrimidine. Cyclization of 6-amino-2,3-dihydro- $1 H$-pyrimidin-4one derivatives $\mathbf{3}$ or $\mathbf{6}$ with different aryl aldehydes $\mathbf{2 1}$ under different reaction conditions afforded pyrido[2,3$d: 6,5-d^{\prime}$ ]dipyrimidine derivatives 123 in good yields (Scheme 57, Table 25). ${ }^{109,127}$

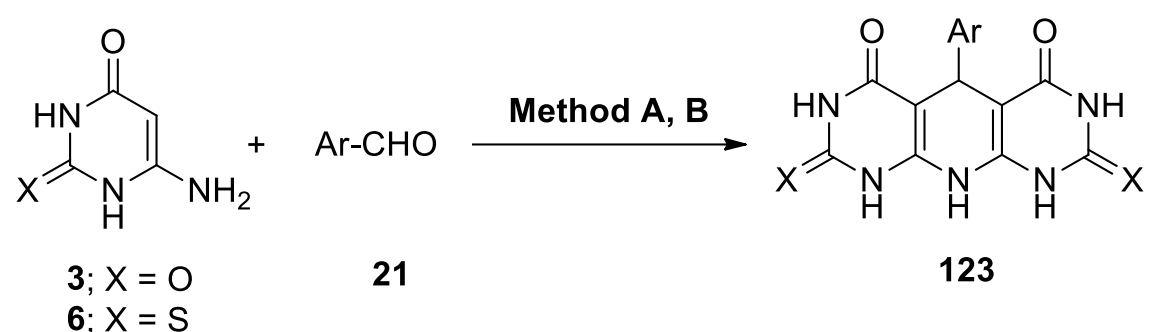

Method A: $\mathrm{CH}_{3} \mathrm{OH}, \mathrm{HCl}$, stirring, r.t., $3 \mathrm{~h}$

Method B: SBA-15-SO ${ }_{3} \mathrm{H}$., solvent free, $120^{\circ} \mathrm{C}$

Scheme 57. Synthesis of pyrido[2,3-d:6,5-d']dipyrimidine derivatives 123.

Table 25. \% Yields of compounds 123

\begin{tabular}{|c|c|c|c|c|}
\hline Method & $\mathrm{Ar}$ & $\mathrm{x}$ & Yield\% & Ref \\
\hline & $\left(2-\mathrm{HO}^{-} \mathrm{C}_{6} \mathrm{H}_{4}, 4-\mathrm{HO}-\mathrm{C}_{6} \mathrm{H}_{4}, 4-\mathrm{H}_{3} \mathrm{CO}-\mathrm{C}_{6} \mathrm{H}_{4}, 2-\mathrm{HO}-3-\right.$ & & & \\
\hline \multirow[t]{3}{*}{ A } & $\mathrm{H}_{3} \mathrm{CO}-\mathrm{C}_{6} \mathrm{H}_{3}, 2-\mathrm{HO}-5-\mathrm{Br}-\mathrm{C}_{6} \mathrm{H}_{3}, 2-\mathrm{HO}-3-\mathrm{H}_{3} \mathrm{CO}-5-\mathrm{Br}-$ & $\mathrm{S}$ & $66-82$ & 109 \\
\hline & $\left.\mathrm{C}_{6} \mathrm{H}_{2}\right)$ & & & \\
\hline & $\left(\mathrm{C}_{6} \mathrm{H}_{5}, 4-\mathrm{O}_{2} \mathrm{~N}-\mathrm{C}_{6} \mathrm{H}_{4}, 4-\mathrm{Cl}-\mathrm{C}_{6} \mathrm{H}_{4}, 2,4-\mathrm{Cl}_{2}-\mathrm{C}_{6} \mathrm{H}_{4}, 2-\mathrm{Br}-\right.$ & & & \\
\hline \multirow[t]{3}{*}{ B } & $\mathrm{C}_{6} \mathrm{H}_{4}, 3-\mathrm{O}_{2} \mathrm{~N}-\mathrm{C}_{6} \mathrm{H}_{4}, 4-\mathrm{H}_{3} \mathrm{C}-\mathrm{C}_{6} \mathrm{H}_{4}, 4-\mathrm{H}_{3} \mathrm{CCONH}-$ & & & \\
\hline & $\mathrm{C}_{6} \mathrm{H}_{4} ; 4-\mathrm{HO}^{-} \mathrm{C}_{6} \mathrm{H}_{4}, 2-\mathrm{HO}-6-\mathrm{Br}-\mathrm{C}_{6} \mathrm{H}_{3}, 3-\mathrm{Cl}_{-} \mathrm{C}_{6} \mathrm{H}_{4}, 4-$ & 0 & 73-98 & 127 \\
\hline & $\left.\mathrm{H}_{3} \mathrm{CO}-\mathrm{C}_{6} \mathrm{H}_{4}\right)$ & & & \\
\hline
\end{tabular}

Pyrido[2,3-d:6,5-d']dipyrimidine derivatives $125 \mathrm{a}-\mathrm{j}$ could also be synthesized in good yields through onepot reaction of aryl aldehydes $\mathbf{2 1}$ with aminouracil $\mathbf{3}$ and thiobarbituric acid (124) using DBU as a nitrogenbased organocatalyst in ethanol at reflux (Scheme 58, Table 26). ${ }^{128}$ 


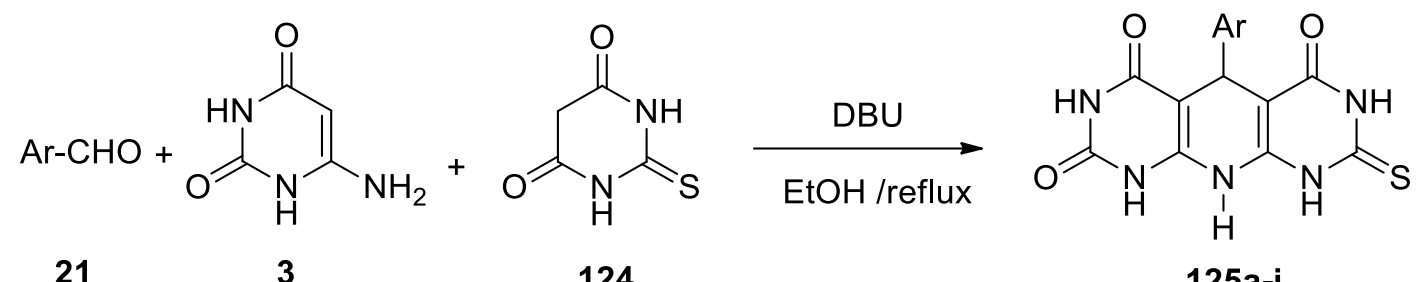

21 3

124

$125 a-j$

Scheme 58. Synthesis of pyrido[2,3-d:6,5-d']dipyrimidine derivatives 125 a-j.

Table 26. \% Yields of compounds 125a-j

\begin{tabular}{ccc}
\hline Products & $\mathrm{Ar}$ & Yield\% \\
\hline a & $\mathrm{C}_{6} \mathrm{H}_{5}$ & 83 \\
b & $4-\mathrm{H}_{3} \mathrm{C}-\mathrm{C}_{6} \mathrm{H}_{4}$ & 72 \\
c & $4-\mathrm{Cl}-\mathrm{C}_{6} \mathrm{H}_{4}$ & 78 \\
d & $4-\mathrm{H}_{3} \mathrm{CO}-\mathrm{C}_{6} \mathrm{H}_{4}$ & 81 \\
e & $3,4-\mathrm{H}_{3} \mathrm{CO}-\mathrm{C}_{6} \mathrm{H}_{4}$ & 79 \\
f & 4- $\mathrm{HO}-\mathrm{C}_{6} \mathrm{H}_{4}$ & 89 \\
g & 3- ${ }_{2} \mathrm{~N}-\mathrm{C}_{6} \mathrm{H}_{4}$ & 82 \\
h & 2-Furanyl & 81 \\
i & 2-Thienyl & 78 \\
j & 2-Pyrrolyl & 83 \\
\hline
\end{tabular}

3.2.2.5.4. Synthesis of $\mathbf{2 , 5 , 7 , 9 , 1 1 - p e n t a a z a p h e n a l e n e s . ~ M a n n i c h ~ r e a c t i o n ~ o f ~ 6 - a m i n o - 2 - t h i o x o - 2 , 3 - ~}$ dihydropyrimidin-4(1H)-one (6) with each of primary amines 126 and excess of formaldehyde solution 97 in ethanol afforded thioxo-5,6,9,10-tetrahydro- $4 \mathrm{H}, 8 \mathrm{H}-2,5,7,9,11$-pentaazaphenalene-3-ones 127a-k in good yields. The synthesized compounds were screened for antimicrobial activity and showed significant activities against Escherichia coli, Pseudomonas aeruginosa, Staphylococcus aureus, Candida albicans, Geotrichum candidum, and Trichophyton rubrum. It was reported that the introduction of aromatic amine (as in compounds $127 \mathbf{d}-\mathbf{k}$ ) improved the activity 1-3 times more than the introduction of aliphatic amines (as in compounds 127a-c) (Scheme 59, Table 27). ${ }^{129}$

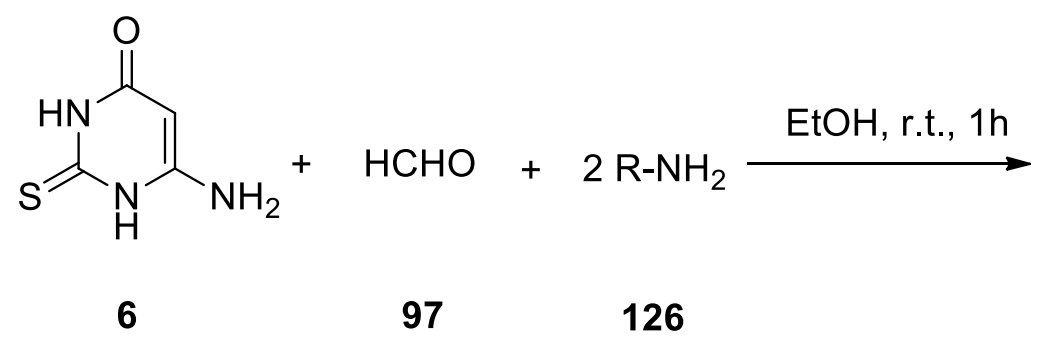<smiles>[R]N1Cc2c3n(c(=S)[nH]c2=O)CN([R])CN3C1</smiles>

127a-k

Scheme 59. Synthesis of thioxo-5,6,9,10-tetrahydro-4H,8H-2,5,7,9,11-pentaazaphenalene-3-ones. 
Table 27. \% Yields of compounds 127a-k

\begin{tabular}{|c|c|c|}
\hline Products & $\mathrm{R}$ & Yeild\% \\
\hline a & $-\mathrm{CH}_{2} \mathrm{CH}_{3}$ & 93 \\
\hline b & $-\mathrm{CH}_{2} \mathrm{CH}\left(\mathrm{CH}_{3}\right)$ & 95 \\
\hline c & $-\mathrm{CH}_{2} \mathrm{CH}_{2} \mathrm{CH}_{2} \mathrm{CH}_{3}$ & 92 \\
\hline d & $-\mathrm{H}_{2} \mathrm{CC}_{6} \mathrm{H}_{5}$ & 85 \\
\hline e & $-\mathrm{C}_{6} \mathrm{H}_{5}$ & 82 \\
\hline$f$ & $3-\mathrm{H}_{3} \mathrm{CO}-\mathrm{C}_{6} \mathrm{H}_{4}$ & 94 \\
\hline g & $3-\mathrm{H}_{3} \mathrm{C}-\mathrm{C}_{6} \mathrm{H}_{4}$ & 85 \\
\hline h & $4-\mathrm{H}_{3} \mathrm{C}-\mathrm{C}_{6} \mathrm{H}_{4}$ & 87 \\
\hline $\mathbf{i}$ & $4-\mathrm{Cl}-\mathrm{C}_{6} \mathrm{H}_{4}$ & 90 \\
\hline $\mathbf{j}$ & $4-\mathrm{Br}-\mathrm{C}_{6} \mathrm{H}_{4}$ & 89 \\
\hline k & 2-Naphthyl & 83 \\
\hline
\end{tabular}

3.2.2.6. Fused [6-6-6]systems: (six heteroatoms). 3.2.2.6.1. Synthesis of pyrimido[4,5-g]pteridine. Treatment of 6-aminothiouracil (6) with sodium hypochlorite furnished 6-amino-5-chloro-1,3-dihydrouracil (128) in 87\% yield. Heating of the latter compound in DMF and in the presence of trimethylamine, provided hexahydropyrimido[4,5-g]pteridine 129 in 92\% yield. The latter compound showed moderate anti-microbial activity against the Gram-positive Bacillus subtilis (Scheme 60). ${ }^{106}$<smiles></smiles>

Scheme 60. Synthesis of hexahydropyrimido[4,5-g]pteridine 129.

3.2.3. Synthesis of fused tetracyclic systems. 3.2.3.1. Fused [6-5-6-6]systems: Three heteroatoms. 3.2.3.1.1. Synthesis of indeno[ $\left.2^{\prime}, 1^{`}: 5,6\right]$ pyrido[2,3-d]pyrimidine. Three component reaction of 6 -aminothiouracil (6) with aryl aldehydes 21 and 1,3-indandione (130) in ethanol at reflux using kappa-carrageenan (KCAR) as a catalyst afforded indeno[2',1:5,6]pyrido[2,3-d]pyrimidine derivatives 131a-m in good yields (Scheme 61, Table 28). ${ }^{130}$ 


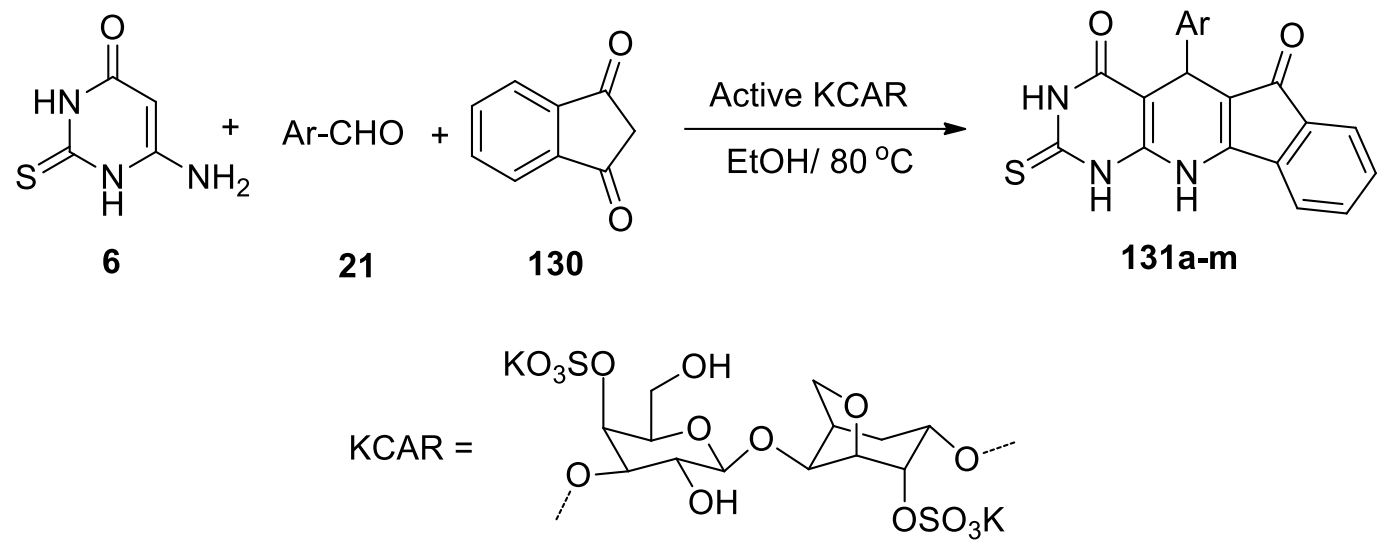

Scheme 61. Synthesis of indeno[2',1':5,6]pyrido [2,3-d]pyrimidine derivatives 131a-m.

Table 28. \% Yields of compounds 131a-m

\begin{tabular}{|c|c|c|}
\hline Products & $\mathrm{Ar}=$ & Yield\% \\
\hline a & $4-\mathrm{Cl}-\mathrm{C}_{6} \mathrm{H}_{4}$ & 94 \\
\hline b & $4-\mathrm{Br}-\mathrm{C}_{6} \mathrm{H}_{4}$ & 82 \\
\hline c & $4-\mathrm{F}-\mathrm{C}_{6} \mathrm{H}_{4}$ & 86 \\
\hline d & $4-\mathrm{F}_{3} \mathrm{C}-\mathrm{C}_{6} \mathrm{H}_{4}$ & 65 \\
\hline e & $4-\mathrm{H}_{3} \mathrm{CO}-\mathrm{C}_{6} \mathrm{H}_{4}$ & 72 \\
\hline$f$ & $4-\mathrm{HO}-\mathrm{C}_{6} \mathrm{H}_{4}$ & 61 \\
\hline g & $3-\mathrm{Cl}-\mathrm{C}_{6} \mathrm{H}_{4}$ & 82 \\
\hline h & $3-\mathrm{F}-\mathrm{C}_{6} \mathrm{H}_{4}$ & 88 \\
\hline $\mathbf{i}$ & $2-\mathrm{HO}-3-\mathrm{H}_{3} \mathrm{CO}-\mathrm{C}_{6} \mathrm{H}_{3}$ & 93 \\
\hline j & $2,6-\mathrm{Cl}_{2}-\mathrm{C}_{6} \mathrm{H}_{3}$ & 82 \\
\hline k & $2-\mathrm{Cl}^{-\mathrm{C}_{6}} \mathrm{H}_{4}$ & 88 \\
\hline I & $3-\mathrm{H}_{3} \mathrm{CO}-\mathrm{C}_{6} \mathrm{H}_{4}$ & 65 \\
\hline m & $3-\mathrm{H}_{3} \mathrm{COOC}-\mathrm{C}_{6} \mathrm{H}_{4}$ & 95 \\
\hline
\end{tabular}

Abdelmoniem et al. ${ }^{124}$ reported the synthesis of spiro[indeno[2', $\left.1^{\prime}: 5,6\right]$ pyrido[2,3-d]pyrimidine-5, $3^{\prime}$ indoline]trione 132 in $90 \%$ yield through a one pot reaction of isatin (89) with 6-aminothiouracil (6) and indanedione (130). The reaction was carried out in distilled water using $p$-TSA as an acidic catalyst (Scheme $62)$.<smiles>Nc1cc(=O)[nH]c(=S)[nH]1</smiles>

6<smiles>O=C1Nc2ccccc2C1=[OH+]</smiles>

89<smiles>O=C1CC(=O)c2ccccc21</smiles>

130
$\mathrm{H}_{2} \mathrm{O}, 20 \mathrm{~mol} \% p$-TSA $80^{\circ} \mathrm{C}$<smiles>C1CCCC1</smiles>

$132 ;(90 \%)$

Scheme 62. Synthesis of spiro[indeno[2', 1':5,6]pyrido[2,3-d] pyrimidine-5,3'-indoline]trione 132. 
Condensation of bis(aldehydes) 29a-d with two moles of both 6-aminouracil (3) and indanedione (130) in acetic acid at reflux gave a series of bis(indeno[2',1':5,6]pyrido[2,3-d]pyrimidines) 133a-d in good yields (Scheme 63). ${ }^{76}$<smiles>O=Cc1ccc(OCCOc2ccc(C=O)cc2)cc1</smiles>

29a-d

3

130

$\mathrm{AcOH}$

reflux, $5 \mathrm{~h}$

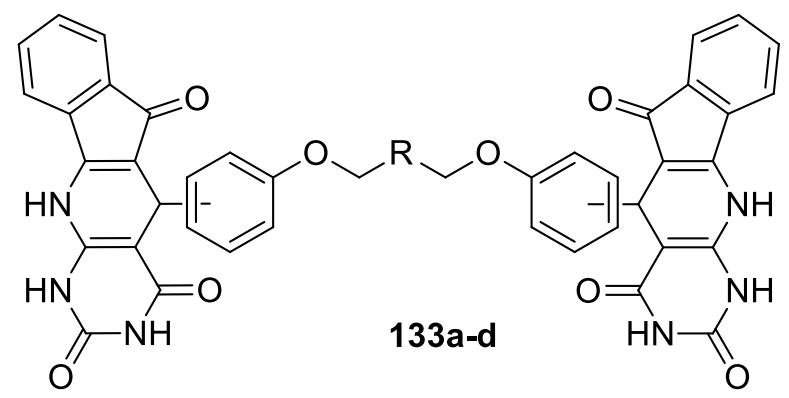
a, $\mathrm{R}=\left(\mathrm{CH}_{2}\right)$, ortho, $(77 \%)$
b, $\mathrm{R}=\left(\mathrm{CH}_{2}\right)_{2}$, ortho, $(84 \%)$

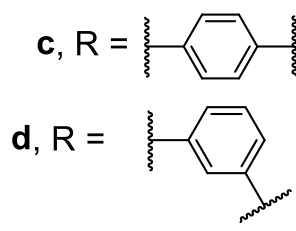

Scheme 63. Synthesis of bis(indeno[2',1':5,6]pyrido[2,3-d]pyrimidines) 133a-d.

3.2.3.2. Fused [5-6-6-6]systems: Three heteroatoms. 3.2.3.2.1. Synthesis of furo[3,2-g]pyrimido[1,6a]quinazolin-3-one. Furo[3,2-g]pyrimido[1,6-a]quinazolin-3-one derivatives 135a and 135b were synthesized in $85 \%$ and $82 \%$ yield, respectively, upon heating acetyl benzofuran derivatives $134 \mathrm{a}$ and $134 \mathrm{~b}$ with 6 aminothiouracil (6) in DMF at reflux (Scheme 64). ${ }^{131}$

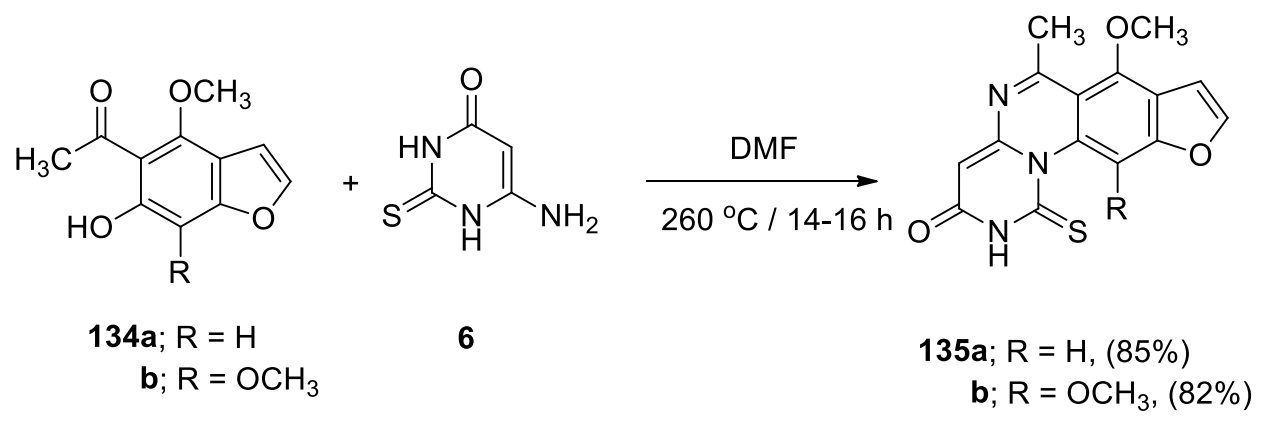

Scheme 64. Synthesis of furo[3,2-g]pyrimido[1,6-a]quinazolin-3-one derivatives 135a and 135b. 
3.2.3.3. Fused [6-6-6-6]systems: Three heteroatoms. 3.2.3.3.1. Synthesis of benzo[g]pyrimido[4,5b]quinolintrione. Three component reaction of 6-aminothiouracil (6) with aryl aldehydes 21 and 2-hydroxy1,4-naphthoquinone (136) in ethanol at reflux afforded benzo[g]pyrimido[4,5- $b]$ quinoline-4,6,11(1H)-trione derivatives 137a-o in good yields (Scheme 65, Table 29). ${ }^{132}$<smiles>CCO[Mg]</smiles>

Scheme 65. Synthesis of benzo[g]pyrimido[4,5-b]quinoline-4,6,11(1H)-trione derivatives 137a-0.

Table 29. \%Yields of compounds $137 a-0$

\begin{tabular}{ccc}
\hline Products & $\mathrm{Ar}$ & Yield\% \\
\hline $\mathbf{a}$ & $\mathrm{C}_{6} \mathrm{H}_{5}$ & 70 \\
$\mathbf{b}$ & $4-\mathrm{Cl}-\mathrm{C}_{6} \mathrm{H}_{4}$ & 75 \\
$\mathbf{c}$ & $3-\mathrm{Cl}-\mathrm{C}_{6} \mathrm{H}_{4}$ & 73 \\
$\mathbf{d}$ & $2-\mathrm{Cl}-\mathrm{C}_{6} \mathrm{H}_{4}$ & 55 \\
$\mathbf{e}$ & $4-\mathrm{Br}-\mathrm{C}_{6} \mathrm{H}_{4}$ & 78 \\
$\mathbf{f}$ & $4-\mathrm{F}-\mathrm{C}_{6} \mathrm{H}_{4}$ & 68 \\
$\mathbf{g}$ & $3-\mathrm{F}-\mathrm{C}_{6} \mathrm{H}_{4}$ & 61 \\
$\mathbf{h}$ & $4-\mathrm{O}_{2} \mathrm{~N}-\mathrm{C}_{6} \mathrm{H}_{4}$ & 67 \\
$\mathbf{i}$ & $2-\mathrm{O}_{2} \mathrm{~N}-\mathrm{C}_{6} \mathrm{H}_{4}$ & 58 \\
$\mathbf{j}$ & $4-\mathrm{HO}-\mathrm{C}_{6} \mathrm{H}_{4}$ & 65 \\
$\mathbf{~}$ & $4-\mathrm{H}_{3} \mathrm{CO}-\mathrm{C}_{6} \mathrm{H}_{4}$ & 77 \\
$\mathbf{~}$ & $3-\mathrm{H}_{3} \mathrm{CO}-\mathrm{C}_{6} \mathrm{H}_{4}$ & 79 \\
$\mathbf{m}$ & $3,4-\left(\mathrm{H}_{3} \mathrm{CO}\right){ }_{2}-\mathrm{C}_{6} \mathrm{H}_{4}$ & 75 \\
$\mathbf{n}$ & $4-\mathrm{H}_{3} \mathrm{COOC}-\mathrm{C}_{6} \mathrm{H}_{4}$ & 58 \\
$\mathbf{0}$ & $4-\mathrm{H}_{3} \mathrm{C}-\mathrm{C}_{6} \mathrm{H}_{4}$ & 70 \\
\hline
\end{tabular}

3.2.3.3.2. Synthesis of pyrido[3,2,1-ij]pyrimido[4,5-b]quinoline-7,5'-pyrrolo[2,3- $d]$ pyrimidine. Reaction of 6aminouracil 3 or 6 with pyrrolo[3,2,1-ij]quinoline-1,2-dione (138) in ethanol at reflux in the presence of $p$-TSA as a catalyst, afforded spirocycle derivatives 139a-d in good yields (Scheme 66, Table 30). ${ }^{133}$

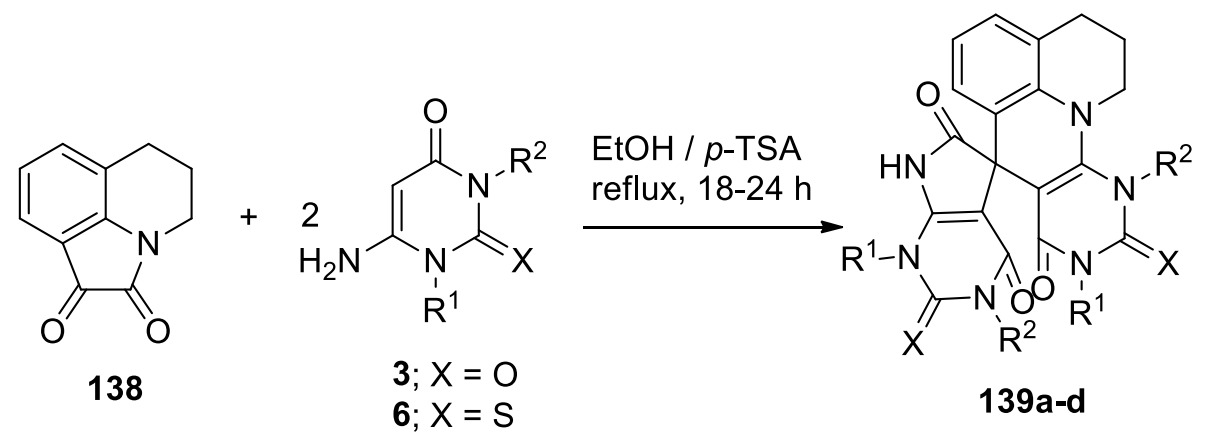

Scheme 66. Synthesis of spiro-pyrido[3,2,1-ij]pyrimido[4,5-b]quinoline-7,5'-pyrrolo[2,3- $d$ ]pyrimidines 139a-d. 
Table 30. \%Yields of compounds 139a-d

\begin{tabular}{ccccc}
\hline Products & $\mathrm{R}^{1}$ & $\mathrm{R}^{2}$ & $\mathrm{X}$ & Yield\% \\
\hline $\mathbf{a}$ & $\mathrm{H}$ & $\mathrm{H}$ & $\mathrm{O}$ & 77 \\
$\mathbf{b}$ & $\mathrm{CH}_{3}$ & $\mathrm{H}$ & $\mathrm{O}$ & 85 \\
$\mathbf{c}$ & $\mathrm{CH}_{3}$ & $\mathrm{CH}_{3}$ & $\mathrm{O}$ & 78 \\
$\mathbf{d}$ & $\mathrm{H}$ & $\mathrm{H}$ & $\mathrm{S}$ & 83 \\
\hline
\end{tabular}

3.2.3.4. Fused [6-6-6-6]systems: Four heteroatoms. 3.2.3.4.1. Synthesis of chromeno[4',3':4,5]pyrido[2,3d]pyrimidine. Reaction of 2-dimethylaminomethylenechromanone (140) with 6-amino-2 thioxopyrimidin-4one (6) in acetic acid at reflux gave a mixture of 10-thioxo-6,9,10,11-tetrahydro-8H-chromeno[3',4':5,6] pyrido[2,3-d]pyrimidin-8-one (141) and 6-((4-oxochroman-3-ylidene)methyl)amino)-2-thioxo-2,3dihydropyrimidin-4(1H)-one (142) in $45 \%$ and 33\% yields, respectively (Scheme 67). ${ }^{134}$

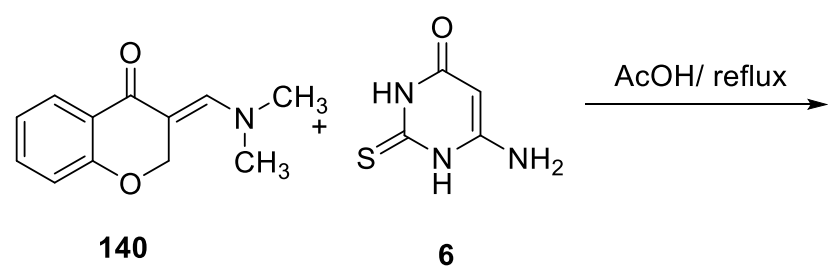<smiles>O=c1[nH]c(=S)[nH]c2nc3c(cc12)COc1ccccc1-3</smiles>

$141 ;(45 \%)$<smiles>O=C1C(=CNc2cc(=O)[nH]c(=S)[nH]2)COc2ccccc21</smiles>

$142 ;(33 \%)$

Scheme 67. Synthesis of chromeno[4',3':4,5]pyrido[2,3-d]pyrimidine-1-one 141.

\section{Conclusions}

Heterocycles, in particular nitrogen-containing heterocycles, have been found to show a range of important applications in various fields. Among the different nitrogen-containing heterocycles, pyrimidine derivatives are the most active class of six-membered heterocycles due to their wide variety of applications. This review highlighted the synthetic utilities of aminouracil and aminothiouracil as versatile precursors for various heterocyclic systems. The heterocyclic compounds described in this review are arranged on the basis of the size of the heterocyclic ring as well as the location and number of heteroatoms. It is hoped that this review of the recent literature will be useful not only for synthetic organic chemists, but also for researchers interested in medicinal and biological chemistry.

\section{References}

1. Li, X.; He, L.; Chen, H.; Wu, W.; Jiang, H. J. Org. Chem. 2013, 78 (8), 3636. https://doi.org/10.1021/j0400162d

2. Santos, C. M. M.; Freitas, M.; Fernandes, E. Eur. J. Med. Chem. 2018, 157, 1460. https://doi.org/10.1016/j.ejmech.2018.07.073

3. Kalaria, P. N.; Karad, S. C.; Raval, D. K. Eur. J. Med. Chem. 2018, 158, 917. https://doi.org/10.1016/j.ejmech.2018.08.040

4. Kerru, N.; Bhaskaruni, S. V. H. S.; Gummidi, L.; Maddila, S. N.; Maddila, S.; Jonnalagadda, S. B. Synth. Commun. 2019, 49 (19), 2437. https://doi.org/10.1080/00397911.2019.1639755 
5. Kerru, N.; Singh, P.; Koorbanally, N.; Raj, R.; Kumar, V. Eur. J. Med. Chem. 2017, 142, 179. https://doi.org/10.1016/j.ejmech.2017.07.033

6. $\quad$ Eftekhari-Sis, B.; Zirak, M.; Akbari, A. Chem. Rev. 2013, 113 (5), 2958. https://doi.org/10.1021/cr300176g

7. Ju, Y.; Varma, R. S. J. Org. Chem. 2006, 71 (1), 135.

https://doi.org/10.1021/jo051878h

8. Leeson, P. D.; Springthorpe, B. Nat. Rev. Drug Discov. 2007, 6 (11), 881.

https://doi.org/10.1038/nrd2445

9. $\quad$ Fang, W. Y.; Ravindar, L.; Rakesh, K. P.; Manukumar, H. M.; Shantharam, C. S.; Alharbi, N. S.; Qin, H. L. Eur. J. Med. Chem. 2019, 173, 117. https://doi.org/10.1016/i.ejmech.2019.03.063

10. Kerru, N.; Singh-Pillay, A.; Awolade, P.; Singh, P. Eur. J. Med. Chem. 2018, 152 (May), 436. https://doi.org/10.1016/j.ejmech.2018.04.061

11. Smith, B. R.; Eastman, C. M.; Njardarson, J. T. J. Med. Chem. 2014, 57 (23), 9764. https://doi.org/10.1021/jm501105n

12. Ansari, A.; Ali, A.; Asif, M.; Shamsuzzaman. New J. Chem. 2016, 41 (1), 16. https://doi.org/10.1039/C6NJ03181A

13. Kumari, S.; Kishore, D.; Paliwal, S.; Chauhan, R.; Dwivedi, J.; Mishra, A. Mol. Divers. 2016, 20 (1), 185. https://doi.org/10.1007/s11030-015-9596-0

14. Lagoja, I. M. Chem. Biodivers. 2005, 2 (1), 1. https://doi.org/10.1002/cbdv.200490173

15. Sharma, V.; Chitranshi, N.; Agarwal, A. K. Int. J. Med. Chem. 2014, 2014, 1. https://doi.org/10.1155/2014/202784

16. Sharma, P.; Rane, N.; Gurram, V. . K. Bioorg. Med. Chem. Lett. 2004, 14 (16), 4185. https://doi.org/10.1016/j.bmcl.2004.06.014

17. Desai, N. C.; Bhatt, N.; Somani, H.; Trivedi, A. Eur. J. Med. Chem. 2013, 67, 54. https://doi.org/10.1016/i.ejmech.2013.06.029

18. Agarwal, N.; Raghuwanshi, S. K.; Upadhyay, D. N.; Shukla, P. K.; Ram, V. J. Bioorg. Med. Chem. Lett. 2000, 10 (8), 703. https://doi.org/10.1016/S0960-894X(00)00091-3

19. Babu, K. S.; Prabhakar, V.; Ravindranath, L. K.; Latha, J. Int. J. Pharma Res. Rev. 2015, 4 (1), 23.

20. Sondhi, S. M.; Jain, S.; Dwivedi, A. D.; Shukla, R.; Raghubir, R. Indian J. Chem. - Sect. B Org. Med. Chem. 2008, 47 (1), 136.

21. Vega, S.; Alonso, J.; Diaz, J. A.; Junquera, F. J. Heterocycl. Chem 1990, 27 (2), 269.

22. Hannah, D. R.; Stevens, M. F. G. J. Chem. Res. 2003, 398.

23. Rana, K.; Kaur, B.; Kumar, B. Indian J. Chem. 2004, 173, 2004.

24. Smith, P. A. S.; Kan, R. O. J. Org. Chem. 1964, 29 (8), 2261. https://doi.org/10.1021/j001031a037

25. Balzarini, J.; McGuigan, C. J. Antimicrob. Chemother. 2002, 50 (1), 5 . https://doi.org/10.1093/jac/dkf037

26. Lee, H. W.; Bok, Y. K.; Joong, B. A.; Sung, K. K.; Lee, J. H.; Jae, S. S.; Soon, K. A.; Lee, S. J.; Seung, S. Y. Eur. J. Med. Chem. 2005, 40 (9), 862. https://doi.org/10.1016/j.ejmech.2005.03.019

27. Juby, P. F.; Hudyma, T. W.; Brown, M.; Essery, J. M.; Partyka, R. A. J. Med. Chem. 1979, 22 (3), 263. https://doi.org/10.1021/jm00189a009

28. Abu-Hashem, A. A.; Youssef, M. M.; Hussein, H. A. R. J. Chinese Chem. Soc. 2011, 58 (1), 41. https://doi.org/10.1002/jccs.201190056

29. Abu-Hashem, A. A.; El-Shehry, M. F.; Badria, F. A.-E. Acta Pharm. 2010, 60 (3), 311. https://doi.org/10.2478/v10007-010-0027-6

30. Rahaman, S. A.; Rajendra Pasad, Y.; Kumar, P.; Kumar, B. Saudi Pharm. J. 2009, 17 (3), 255. https://doi.org/10.1016/j.jsps.2009.08.001

31. Nezu, Y.; Miyazaki, M.; Sugiyama, K.; Wada, N.; Kajiwara, I.; Miyazawa, T. Pestic. Sci. 1996, 47 (2), 115. 
https://doi.org/10.1002/(SICl)1096-9063(199606)47:2<115::AID-PS397>3.0.CO;2-R

32. Xie, F.; Zhao, H.; Zhao, L.; Lou, L.; Hu, Y. Bioorg. Med. Chem. Lett. 2009, 19 (1), 275. https://doi.org/10.1016/j.bmcl.2008.09.067

33. Kaldrikyan, M. A.; Grigoryan, L. A.; Geboyan, V. A.; Arsenyan, F. G.; Stepanyan, G. M.; Garibdzhanyan, B. T. Pharm. Chem. J. 2000, 34 (10), 521. https://doi.org/10.1023/A:1010398911988

34. Lu, G. qing; Li, X. yang; Mohamed O, K.; Wang, D.; Meng, F. hao. Eur. J. Med. Chem. 2019, 171, 282. https://doi.org/10.1016/i.ejmech.2019.03.047

35. Mohamed, R.; Mohamed, S.; Elrady, A.; Usef, K. Mol. Divers. 2016, 20, 153. https://doi.org/10.1007/s11030-015-9595-1

36. Raic, S. J. Med. Chem. 1999, 42, 2673. https://doi.org/10.1021/jm991017z

37. Chaudhuri, N. G. K. and L. N. J. Chem. Soc., Perkin Trans. I 1991, 1677.

38. Platonova, Y. B.; Volov, A. N.; Tomilova, L. G. Bioorg. Med. Chem. Lett. 2020, 30 (16), 127351. https://doi.org/10.1016/j.bmcl.2020.127351

39. Isobe, Y.; Tobe, M.; Inoue, Y.; Isobe, M.; Tsuchiya, M.; Hayashi, H. Bioorg. Med. Chem. 2003, 11, 4933. https://doi.org/10.1016/j.bmc.2003.09.012

40. Marchal, J. A.; Núñez, M. C.; Suárez, I.; Díaz-Gavilán, M.; Gómez-Vidal, J. A.; Boulaiz, H.; RodríguezSerrano, F.; Gallo, M. A.; Espinosa, A.; Aránega, A.; et al. Breast Cancer Res. Treat. 2007, 105 (3), 237. https://doi.org/10.1007/s10549-006-9450-2

41. Semenov, V. E.; Mikhailov, A. S.; Voloshina, A. D.; Kulik, N. V.; Nikitashina, A. D.; Zobov, V. V.; Kharlamov, S. V.; Latypov, S. K.; Reznik, V. S. Eur. J. Med. Chem. 2011, 46 (9), 4715. https://doi.org/10.1016/j.ejmech.2011.05.034

42. Rafehi, M.; Müller, C. E. Pharmacol. Ther. 2018, 190, 24. https://doi.org/10.1016/j.pharmthera.2018.04.002

43. Tolstikov, G. A.; Myshkin, I. V. A.; Baltina, I. L. A.; Murinov, I. Y. I.; S, I. D. V. Pharm. Chem. J. 1997, 30 (5), 320. https://doi.org/10.1007/BF02333971

44. Bruno, O.; Brullo, C.; Bondavalli, F.; Schenone, S.; Ranise, A.; Arduino, N.; Bertolotto, M. B.; Montecucco, F.; Ottonello, L.; Dallegri, F.; et al. J. Med. Chem. 2007, 50 (15), 3618.

https://doi.org/10.1021/jm0704402

45. Evdokimov, N. M.; Kireev, A. S.; Yakovenko, A. A.; Antipin, M. Y.; Magedov, I. V.; Kornienko, A. Tetrahedron Lett. 2006, 47 (52), 9309. https://doi.org/10.1016/j.tetlet.2006.10.110

46. Magedov, I. V; Manpadi, M.; Ogasawara, M. A.; Dhawan, A. S.; Rogelj, S.; Van, S.; Steelant, W. F. A.; Evdokimov, N. M.; Uglinskii, P. Y.; Elias, E. M.; et al. J. Med. Chem. 2008, 51, 2561. https://doi.org/10.1021/im701499n

47. Magedov, I. V.; Luchetti, G.; Evdokimov, N. M.; Manpadi, M.; Steelant, W. F. A.; Van slambrouck, S.; Tongwa, P.; Antipin, M. Y.; Kornienko, A. Bioorg. Med. Chem. Lett. 2008, 18 (4), 1392.

https://doi.org/10.1016/j.bmcl.2008.01.019

48. Magedov, I. V.; Frolova, L.; Manpadi, M.; Bhoga, U. D.; Tang, H.; Evdokimov, N. M.; George, O.; Hadje Georgiou, K.; Renner, S.; Getlik, M.; et al. J. Med. Chem. 2011, 54 (12), 4234.

https://doi.org/10.1021/jm200410r

49. Elwahy, A. H. M.; Shaaban, M. R. Curr. Org. Synth. 2010, 7 (5), 433. https://doi.org/10.2174/157017910792246117

50. Riyadh, S. M.; Abdelhamid, I. A.; Al-Matar, H. M.; Hilmy, N. M.; Elnagdi, M. H. Heterocycles 2008, 75 (8), 1849. https://doi.org/10.3987/REV-07-625

51. Elnagdi, M. H.; Al-Awadi, N. A.; Abdelhamid, I. A. Adv. Heterocycl. Chem. 2009, 97 (08), 1. https://doi.org/10.1016/S0065-2725(08)00201-8

52. Ghozlan, S. A. S.; Abdelmoniem, A. M.; Abdelhamid, I. A. Curr. Org. Chem. 2011, 15 (17), 3098. https://doi.org/10.2174/138527211798357137 
53. Al-mousawi, S. M.; Sherief, M.; Abdelhamid, I. A.; Elnagdi, M. H. Curr. Org. Chem. 2011, 15 (19), 3503. https://doi.org/10.2174/138527211797374760

54. Riyadh, S. M.; Abdelhamid, I. A.; Lbrahim, H. M.; Al-Matar, H. M.; Elnagdia, M. H. Heterocycles 2007, 71 (12), 2545.

https://doi.org/10.3987/REV-07-618

55. Elnagdi, M. H.; Ghozlan, S. A. S.; Abdelhamid, I. A. Arkivoc 2008, 2008 (10), 54.

https://doi.org/10.3998/ark.5550190.0009.a06

56. Abdella, A. M.; Abdelmoniem, A. M.; Abdelhamid, I. A.; Elwahy, A. H. M. J. Heterocycl. Chem. 2020, 57

(4), 1476.

https://doi.org/10.1002/jhet.3883

57. Johnson, T. B.; Hahn, D. A. Chem. Rev. 1933, 13 (2), 193.

https://doi.org/10.1021/cr60045a002

58. Mortimer, P. I. Aust. J. Chem. 1968, 21 (2), 467.

https://doi.org/10.1071/CH9680467

59. Gütschow, M.; Hecker, T.; Thiele, A.; Hauschildt, S.; Eger, K. Bioorg. Med. Chem. 2001, 9 (4), 1059. https://doi.org/10.1016/S0968-0896(00)00323-0

60. Chern, J.; Wise, D. S.; Butler, W.; Townsend, L. B. J. Org. Chem. 1988, 53 (3), 5622.

https://doi.org/10.1021/jo00259a005

61. Zajac, M. A.; Zakrzewski, A. G.; Kowal, M. G.; Narayan, S. Synth. Commun. 2003, 33 (19), 3291.

https://doi.org/10.1081/SCC-120023986

62. Ishiyama, H.; Nakajima, H.; Nakata, H.; Kobayashi, J. Bioorg. Med. Chem. 2009, 17 (13), 4280. https://doi.org/10.1016/j.bmc.2009.05.036

63. Crepaldi, P.; Cacciari, B.; Bonache, M. C.; Spalluto, G.; Varani, K.; Borea, P. A.; Kügelgen, I. von; Hoffmann, K.; Pugliano, M.; Razzari, C.; et al. Bioorg. Med. Chem. 2009, 17 (13), 4612.

https://doi.org/10.1016/j.bmc.2009.04.061

64. Cheng, C. C.; Lewis, L. R. J. Heterocycl. Chem. 1964, 1 (5), 260.

https://doi.org/10.1002/jhet.5570010512

65. Fujita, T.; Takeda, Y.; Han-dong, S.; Minami, Y.; Marunaka, T.; Takeda, S.; Yamada, Y.; Togo, T. Planta Med. 1988, 54 (05), 414.

https://doi.org/10.1055/s-2006-962485

66. Abu-Hashem, A. A.; Aly, A. S. Synth. Commun. 2017, 47 (24), 2417.

https://doi.org/10.1080/00397911.2017.1381261

67. Abu-hashem, A. A. J. Heterocycl. Chem 2019, 56 (3), 886.

https://doi.org/10.1002/jhet.3466

68. Abu-Hashem, A. A.; Al-Hussain, S. A.; Zaki, M. E. A. Molecules 2020, 25 (1), 220.

https://doi.org/10.3390/molecules25010220

69. Gao, M.; Wang, M.; Meyer, J. A.; Peters, J. S.; Zarrinmayeh, H.; Territo, P. R.; Hutchins, G. D.; Zheng, Q. H. Bioorg. Med. Chem. Lett. 2017, 27 (12), 2727.

https://doi.org/10.1016/j.bmcl.2017.04.052

70. Abdel-Latif, E.; Fahad, M. M.; El-Demerdash, A.; Ismail, M. A. J. Heterocycl. Chem. 2020, 57 (8), 3071. https://doi.org/10.1002/jhet.4012

71. Yan, G.; Hao, L.; Niu, Y.; Huang, W.; Wang, W.; Xu, F.; Liang, L.; Wang, C.; Jin, H.; Xu, P. Eur. J. Med. Chem. 2017, 137, 462.

https://doi.org/10.1016/j.ejmech.2017.06.020

72. Ibrahim, D. A.; Lasheen, D. S.; Zaky, M. Y.; Ibrahim, A. W.; Vullo, D.; Ceruso, M.; Supuran, C. T.; Abou El Ella, D. A. Bioorg. Med. Chem. 2015, 23 (15), 4989.

https://doi.org/10.1016/j.bmc.2015.05.019

73. Zhang, F.; Li, C.; Liang, X. Green Chem. 2018, 20 (9), 2057.

https://doi.org/10.1039/C7GC03812G

74. Brahmachari, G.; Begam, S.; Nurjamal, K. ChemistrySelect 2018, 3 (12), 3400. https://doi.org/10.1002/slct.201800488

75. Brahmachari, G.; Mandal, M.; Karmakar, I.; Nurjamal, K.; Mandal, B. ACS Sustain. Chem. Eng. 2019, 7 (6), 
6369.

https://doi.org/10.1021/acssuschemeng.9b00133

76. Abdelmoniem, A. M.; Ghozlan, S. A. S.; Butenschön, H.; Abdelmoniem, D. M.; Elwahy, A. H. M.; Abdelhamid, I. A. Arkivoc 2019, 2019 (5), 163. https://doi.org/10.24820/ark.5550190.p010.875

77. Li, C.; Zhang, F. Synlett 2017, 28 (11), 1315. https://doi.org/10.1055/s-0036-1588757

78. Bayat, M.; Nasri, S. J. Mol. Struct. 2018, 1154, 366. https://doi.org/10.1016/j.molstruc.2017.10.056

79. Dommaraju, Y.; Borthakur, S.; Rajesh, N.; Prajapati, D. RSC Adv. 2015, 5 (31), 24327. https://doi.org/10.1039/C5RA00796H

80. Ahmadi Sabegh, M.; Khalafy, J.; Etivand, N. J. Heterocycl. Chem. 2018, 55 (11), 2610. https://doi.org/10.1002/jhet.3320

81. Kim, D. G.; Osheko, K. Y.; Frolova, T. V. Russ. J. Org. Chem. 2017, 53 (12), 1899. https://doi.org/10.1134/S1070428017120235

82. Cai, D.; Zhang, Z. H.; Chen, Y.; Yan, X. J.; Zou, L. J.; Wang, Y. X.; Liu, X. Q. Molecules 2015, 20 (9), 16419. https://doi.org/10.3390/molecules200916419

83. Li, R.; Wang, H.; Wang, J.; Cheng, M. Bioorg. Med. Chem. Lett. 2020, 30 (2), 126807. https://doi.org/10.1016/i.bmcl.2019.126807

84. Abu-Hashem, A. A.; Hussein, H. A. R.; Abu-zied, K. M. Med. Chem. Res. 2017, 26 (1), 120. https://doi.org/10.1007/s00044-016-1733-5

85. Zhang, H. J.; Wang, S. Ben; Wen, X.; Li, J. Z.; Quan, Z. S. Med. Chem. Res. 2016, 25 (7), 1287. https://doi.org/10.1007/s00044-016-1559-1

86. Mamaghani, M.; Taati, Z.; Rasoulian, M.; Yousefizad, J.; Toraji, N. J. CHEM. Res. 2016, 40, 29. https://doi.org/10.3184/174751916X14495860660659

87. Fares, M.; Abd El Hadi, S. R.; Eladwy, R. A.; Shoun, A. A.; Abdel-Aziz, M. M.; Eldehna, W. M.; Abdel-Aziz, H. A.; Keller, P. A. Org. Biomol. Chem. 2018, 16 (18), 3389. https://doi.org/10.1039/C8OB00627J

88. Nassar, E.; El-Badry, Y. A.-M.; El Kazaz, H. Chem. Pharm. Bull. 2016, 64 (6), 558. https://doi.org/10.1248/cpb.c15-00922

89. Gomha, S. M.; Mohamed, A. M. G.; Zaki, Y. H.; Ewies, M. M.; Elroby, S. A. J. Heterocycl. Chem. 2018, 55 (5), 1147. https://doi.org/10.1002/jhet.3146

90. Farghaly, T. A.; Masaret, G. S.; Muhammad, Z. A.; Harras, M. F. Bioorg. Chem. 2020, 98 (March), 103761. https://doi.org/10.1016/j.bioorg.2020.103761

91. Gomha, S.; Abdallah, M.; Abd El-Aziz, M.; Serag, N. Turkish J. Chem. 2016, 40 (3), 484. https://doi.org/10.3906/kim-1510-25

92. Gomha, S. M.; Ahmed, S. A.; Abdelhamid, A. O. Molecules 2015, 20 (1), 1357. https://doi.org/10.3390/molecules20011357

93. Abdelrazek, F. M.; Gomha, S. M.; Abdel-aziz, H. M.; Farghaly, M. S.; Metz, P.; Abdel-Shafy, A. J. Heterocycl. Chem. 2020, 57 (4), 1759. https://doi.org/10.1002//het.3901

94. Muhammad, Z. A.; Edrees, M. M.; Faty, R. A. M.; Gomha, S. M.; Alterary, S. S.; Mabkhot, Y. N. Molecules 2017, 22 (7), 1211. https://doi.org/10.3390/molecules22071211

95. Khalifa, N. M.; Al-Omar, M. A.; Alkahtani, H. M.; Bakheit, A. H. J. Chem. 2019, $2019,1$. https://doi.org/10.1155/2019/2635219

96. Khalifa, N. M.; Alkahtani, H. M.; Al-Omar, M. A.; Bakheit, A. H. Russ. J. Gen. Chem. 2019, 89 (8), 1683. https://doi.org/10.1134/S107036321908022X

97. Khalifa, N. M.; Nossier, E. S.; Amr, A. E. Russ. J. Gen. Chem. 2018, 88 (6), 1228. https://doi.org/10.1134/S1070363218060300

98. Abdel-Aziem, A. J. Heterocycl. Chem. 2017, 54 (6), 2985. 
https://doi.org/10.1002/jhet.2906

99. Abdelhamid, A. O.; Gomha, S. M.; Abdelriheem, N. A.; Kandeel, S. M. Molecules 2016, 21 (7), 929. https://doi.org/10.3390/molecules21070929

100. Popova, Y. V.; Osipov, D. V.; Osyanin, V. A.; Klimochkin, Y. N. Russ. J. Org. Chem. 2017, 53 (4), 599. https://doi.org/10.1134/S1070428017040169

101. Ibrahim, M. A.; El-Gohary, N. M. J. Heterocycl. Chem. 2020, 57 (7), 2815. https://doi.org/10.1002/jhet.3991

102. Rashdan, H. R. M.; Roaiah, H. M. F.; Muhammad, Z. A.; Wietrzyk, J.; Milczarek, M.; Soliman, A. M. M. Acta Pol. Pharm. - Drug Res. 2018, 75 (3), 679.

103. Masaret, G. S.; Farghaly, T. A. Curr. Org. Synth. 2018, 15 (1), 126. https://doi.org/10.2174/1570179414666170601121137

104. El, M. T.; Hussein, H. A. R.; Elebiary, N. M.; Hassan, G. S.; Elmessery, S. M.; Elsheakh, A. R.; Nayel, M.; Abdel-aziz, H. A. Bioorg. Chem. 2018, 78, 312.

https://doi.org/10.1016/j.bioorg.2018.03.009

105. Fares, I. M. Z.; Mekky, A. E. M.; Abdelhamid, I. A.; Elwahy, A. H. M. J. Heterocycl. Chem. 2019, 4, 2. https://doi.org/10.1002/jhet.3575

106. Fadda, A. A.; Bayoumy, N. M.; El-Sherbiny, I. M. Drug Dev. Ind. Pharm. 2016, 42 (7), 1094. https://doi.org/10.3109/03639045.2015.1108331

107. Fadda, A. A.; Fekri, A.; Bayoumy, N. M. RSC Adv. 2015, 5 (98), 80844. https://doi.org/10.1039/C5RA14723A

108. Melik-Ohanjanyan, R. G.; Hovsepyan, T. R.; Karakhanyan, G. S.; Israelyan, S. G.; Nersesyan, L. E.; Panosyan, G. A. Russ. J. Org. Chem. 2018, 54 (1), 107. https://doi.org/10.1134/S1070428018010104

109. Abdelgawad, M. A.; Bakr, R. B.; Azouz, A. A. Bioorg. Chem. 2018, 77, 339. https://doi.org/10.1016/j.bioorg.2018.01.028

110. Rad, A. M.; Mokhtary, M. Int. Nano Lett. 2015, 5 (2), 109. https://doi.org/10.1007/s40089-015-0145-8

111. Saberikhah, E.; Mamaghani, M.; Mahmoodi, N. O.; Fallah Shojaei, A. Polycycl. Aromat. Compd. 2020, 0 (0), 1. https://doi.org/10.1080/10406638.2020.1729821

112. Upadhyay, A.; Sharma, L. K.; Singh, V. K.; Krishna, R.; Singh, P. Tetrahedron Lett. 2016, 57 (50), 5599. https://doi.org/10.1016/j.tetlet.2016.10.111

113. Dommaraju, Y.; Bora, S.; Prajapati, D. Org. Biomol. Chem. 2015, 13 (35), 9181. https://doi.org/10.1039/C5OB01484K

114. Khondekar Nurjamal, G. B. ChemistrySelect 2019, 4, 2363. https://doi.org/10.1002/slct.201803508

115. Klenc, J.; Raux, E.; Barnes, S.; Sullivan, S.; Duszynska, B.; Bojarski, A. J.; Strekowski, L. J. Heterocycl. Chem. 2009, 46 (November), 1259.

116. Sallam, H. A.; Elgubbi, A. S.; El-Helw, E. A. E. Synth. Commun. 2020, 50 (13), 2066. https://doi.org/10.1080/00397911.2020.1765258

117. Khodabakhshi, M. R.; Kiamehr, M.; Moghaddam, F. M.; Villinger, A.; Langer, P. ChemistrySelect 2018, 3 (41), 11671. https://doi.org/10.1002/slct.201801869

118. Abdallah, Y. M.; Shalabi, K.; Bayoumy, N. M. J. Mol. Struct. 2018, 1171, 658. https://doi.org/10.1016/j.molstruc.2018.06.045

119. Bayat, M.; Nasri, S.; Mohammadali, M. R. Monatshefte für Chemie - Chem. Mon. 2017, 148 (10), 1833. https://doi.org/10.1007/s00706-017-2006-9

120. Poomathi, N.; Mayakrishnan, S.; Muralidharan, D.; Srinivasan, R.; Perumal, P. T. Green Chem 2015, 17, 3362. https://doi.org/10.1039/C5GC00006H

121. Malki, W. H.; Gouda, A. M.; Ali, H. E. A.; Al-Rousan, R.; Samaha, D.; Abdalla, A. N.; Bustamante, J.; Abd Elmageed, Z. Y.; Ali, H. I. Eur. J. Med. Chem. 2018, 152, 31. 
https://doi.org/10.1016/j.ejmech.2018.04.029

122. Hovsepyan, T. R.; Karakhanyan, G. S.; Israelyan, S. G.; Panosyan, G. A. Russ. J. Gen. Chem. 2018, 88 (6), 1114. https://doi.org/10.1134/S1070363218060117

123. Baharfar, R.; Azimi, R. J. Chem. Sci. 2015, 127 (8), 1389.

https://doi.org/10.1007/s12039-015-0910-2

124. Abdelmoniem, A. M.; Hassaneen, H. M. E.; Abdelhamid, I. A. J. Heterocycl. Chem. 2016, 53 (6), 2084. https://doi.org/10.1002/ihet.2480

125. Mohamed, M. F.; Abdelmoniem, A. M.; Elwahy, A. H. M.; Abdelhamid, I. A. Curr. Cancer Drug Targets 2018, 18, 372.

https://doi.org/10.2174/1568009617666170630143311

126. Naidu, P. S.; Kolita, S.; Majumder, S.; Bhuyan, P. J. Synthesis 2015, 47 (5), 701. https://doi.org/10.1055/s-0034-1379639

127. Rostamizadeh, S.; Tahershamsi, L.; Zekri, N. J. Iran. Chem. Soc. 2015, 12 (8), 1381. https://doi.org/10.1007/s13738-015-0604-1

128. Bhat, A. R.; Dongre, R. S. J. Taiwan Inst. Chem. Eng. 2015, No. $29,191$. https://doi.org/10.1016/j.jtice.2015.04.020

129. El-mahdy, A. F. M.; El-sherief, H. A. H. RSC Adv. 2016, 6, 92134. https://doi.org/10.1039/C6RA20689A

130. Bayat, M. J. Heterocycl. Chem 2018, 55, 650. https://doi.org/10.1002/jhet.3083

131. Abu-Hashem, A. A. Molecules 2018, 23 (11), 1. https://doi.org/10.3390/molecules23112793

132. Hosseini, F. S.; Bayat, M. J. Sulfur Chem. 2018, 39 (5), 483. https://doi.org/10.1080/17415993.2018.1458850

133. Farshi, H.; Khodaie, M.; Fazlelahi, H. Z.; Rashidi, A.; Joule, J. A.; Baradarani, M. M. J. Heterocycl. Chem. 2017, 55 (1), 91. https://doi.org/10.1002/jhet.3008

134. Ali, K. A.; Abdelhafez, N. A. A.; Ragab, E. A.; Ibrahim, A. A.; Amr, A. E. Russ. J. Gen. Chem. 2015, 85 (12), 2853.

https://doi.org/10.1134/S107036321512035X

\section{Authors' Biographies}

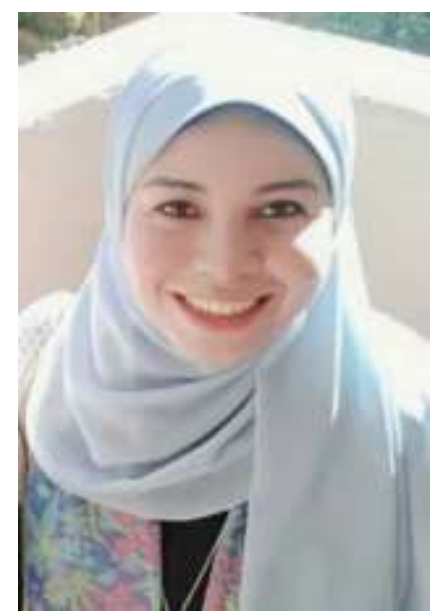

Hadeer M. Diab was born in 1992 in Giza, Egypt. She graduated from the Faculty of Science, Cairo University, Egypt in 2013. She got her M.Sc degree in 2018. 


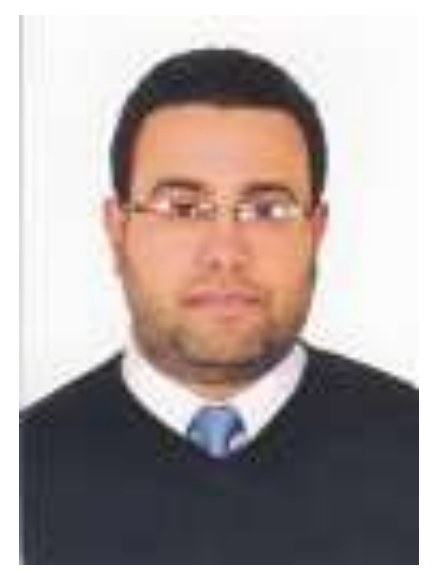

Mostafa E. Salem was born in Egypt in July 1983. He graduated from the Faculty of Science, Cairo University, Egypt in 2003. He got M.Sc. and Ph.D. degrees in 2011 and 2016, respectively, in the field of organic synthesis. In the same year he was appointed as lecturer of Organic chemistry at Cairo University.

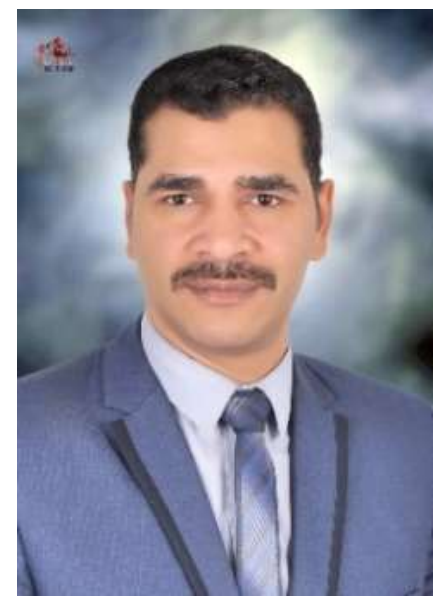

Ismail A. Abdelhamid was born in Egypt in December 1978. He graduated from Cairo University, Egypt in 2001 then he got his M.Sc. and Ph.D. degrees in 2005 and 2007, respectively, at Cairo University in the field of organic synthesis. In 2017 he was appointed as a full Professor of Organic chemistry at Cairo University. He was awarded the Alexander von Humboldt research fellowship in 2008-2011 and in 2014, 2017, and 2019 with Prof. Holger Butenschön, at Hannover University, Germany. He received several research prizes; Cairo University Incentive Award (2012), Cairo University Scientific Excellence Award (2016) and State Incentive Award (2019).

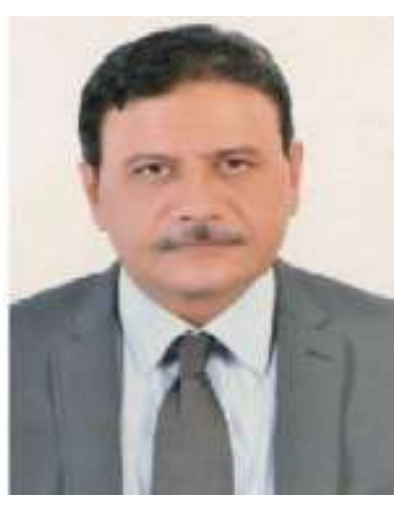

Ahmed H. M. Elwahy was born in 1963 in Giza, Egypt. He graduated from Cairo University, Egypt in 1984 then he got his M.Sc. and Ph.D. degrees in 1988 and 1991, respectively, at Cairo University in the field of organic 
synthesis. He was awarded the Alexander von Humboldt research fellowship in 1998-2000 and in 2003, 2005, 2009, 2010 and 2012 with Prof. Klaus Hafner, at TU Darmstadt, Germany. In 2002 he was appointed as a full Professor of Organic chemistry at Cairo University. In 2001 he received the State-Award in Chemistry and in 2016 received Cairo University Appreciation-Award in Basic Science. He has published around 140 scientific papers in distinguished international journals.

This paper is an open access article distributed under the terms of the Creative Commons Attribution (CC BY) license (http://creativecommons.org/licenses/by/4.0/) 